THE SCIENCE OF MATERIALS

$$
\begin{aligned}
& \text { Progress Report } \\
& \text { July 1, } 1975 \text { - June } 30,1976 \\
& \text { Materials Research Laboratory } \\
& \text { University of Illinots } \\
& \text { Urbena, Illinots 61801 }
\end{aligned}
$$
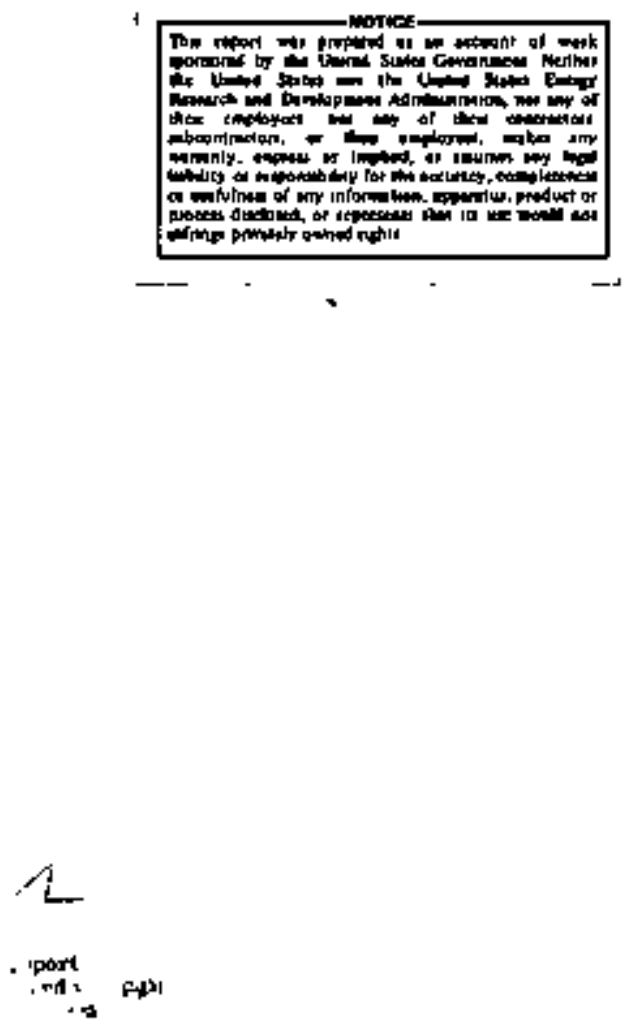

Apr11 1976

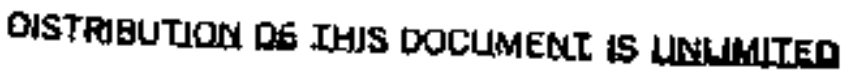

Frepared For

THE U. S, ENERGY RESEARCH AND DEVELOPMENT ADMINISTRATLON

UNOER CONTRACT NO. E(11-1)-1198 


\section{DISCLAIMER}

This report was prepared as an account of work sponsored by an agency of the United States Government. Neither the United States Government nor any agency Thereot, nor any of their employees, makes any warranty, express or implied, or assumes any legal liability or responsibility for the accuracy, completeness, or usefulness of any information, apparatus, product, or process disclosed, or represents that its use would not infringe privately owned rights. Reference herein to any specific commercial product, process, or service by trade name, trademark, manufacturer, or otherwise does not necessarily constitute or imply its endorsement, recommendation, or favoring by the United States Government or any agency thereof. The views and opinions of authors expressed herein do not necessarlly state or reflect those of the United States Government or any agency thereof. 


\section{DISCLAIMER}

Portions of this document may be illegible in electronic image products. Images are produced from the best available original document. 


\section{NOTICE}

This report was prepared as an account of work sponsored by the Dnited States Government. Nether the United States not the Un1ted States Energy Research and Development Administration, nor any of their employees, nor any of their contractors, subcontractors, or their enployees, makes any warranty, express or implied, or assumes any legal liability or responsibility for the accuracy, completeness, or usefulness of any information, apparatus, product or process disclosed or represents that its use would not infringe privately owned rights. 
Th1s Progress Report contains a description of the basic research and results of ERDA Contract E(11-1)-1198 for the period from July 1, 1975 through June $30,1976$.

Research in Metallurgy and Ceramics included the invest1gation of the mechanical properties, stress corrosion cracking. and fracture of metals, alloys and transition metal compounds; the 1rvestigation of the dynamic structure of water and electrolyte solutions at high temperature and pressure; and the investigation of the properties of oxides and of the magnetic properties of alloys.

Solid state Physics research was focussed on the electronic properties of solfds and on defects in crystal structure including radiation damage. Inportant topics of investigation were che effect of dislocations and impurities on the mechanical properties of metals, diffusion processes in superionic conductors, the defect structure of quancuri crystals, high pressure studies of the electronic structure of phosphors, and the magnetic structure of transition metal atows in nonmagnet1c host crystals.

The program is planned to provide an atomic understanding of energy flow, conversion and storage ptocesses and to support with basic research the development of Improved materials for energy applications. 


\section{INDEX OF ERDA ACTIVITIES 1975-76}

\section{Materials Research Laboratory \\ University of I11tnais \\ Urbana, Illino1s 61801}

INTRODUCTION

LIST OF PROJECT TITLES AND PRINCIPAL INVESTIGATORS. . . . . . . . . . 11

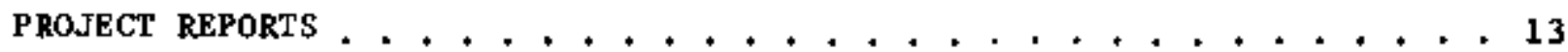

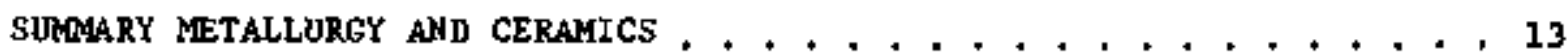

ED-02-01-01-0 Structure of Materials

Paul A. Beck. .................... 19

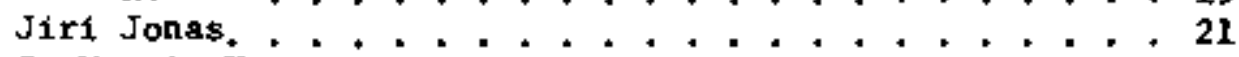

c. Maru1n Wayman. . . . . . . . . . . . . 28

WendelI S, Hiliams ................ 32

ED-02-01-02-0 HechanicaI Properties

Car1 J, Altstetter. . . . . . . . . . . . 42

Howard X. B1rnbaum ................. 46

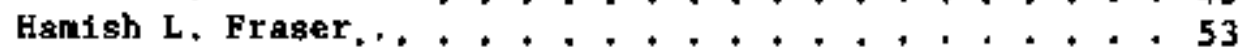

Harvin Hetzger, . . . . . . . . . . . . . . 58

E. Neville Pugh .................... . 61

Charles A. Wert.................. 66

ED=02-01-03-0 Physical Properties

David A. Payne, .................... 72

Theodore J. Rowland .............. 78

SUMPARY SOLIO STATE PHYSICS . . . . . . . . . . . . . 82

ED-02-02-02-0 Experimestal Research

Harry G. Drickamer. . . . . . . . . . . 87

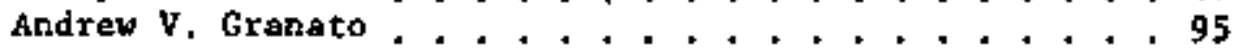

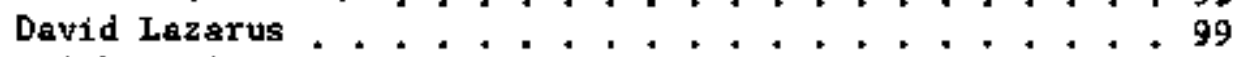

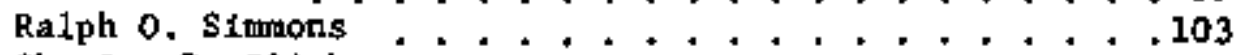

Charles P. Slichter...................... 110

ED-02-02-04-0 Particle-Solid Interactions

James S. Koehler. . . . . . . . . . . . 119

PERSONNEL . . . . . . . . . . . . . . . . . . . . . . . . . 125

PUBLICATIONS. . . . . . . . . . . . . . . . . . . . . . . . 129

Ph.D. dissertations . . . . . . . . . . . . . . . . . . . 135

M.S. DISSERTATIONS . . . . . . . . . . . . . . . . . . . . 136 


\section{INTRODUCTION}

The Materials Research Laboratory of the Untversity of Illinotg is an interdepartmental unit of the College of Engineering organfzed for the purpose of facilitacing interdisciplinary basic research on the propertfes of materials. Faculty from the Departments of Ceramic Englneerting, Chemistry, Electrical Engfneering, Geology, Metallurgy and Mining Engineering, and Physics participate in its activicies, Pollcies and procedures of the Laboratory are the responsibiltty of a Steering Conmittee composed of Professor C. Wert (Metallurgy), Professor H. Drickamer (Chemical Engineering), Professor N, Holonyak, Jr. (Electrical Englreering), Professor A. Frtedberg (Ceramic Engineer1ng), Professor R, Slamons (Phystcs) and Professor R. Maurer (Physics, Director of the Materials Research Laboratory).

Two Advisocy Coumittees advise the Steering Comaittee concerning Laboratory programs. The External Advisary Committee is presently composed of Dr. J. Burke (General Electr1c), Dr. W. Compton (Ford Motor), Dr. M. Nevite, Cha1rman (Argonne Natlonal Laboratory), Professor A. Overhauser (Purdue Untversity), Dr. R. Oriani (U, S, steel), and Professor C. Swenson (Iowa State University).

The Internal Advisory Comittee, conposed of memberg of the Laboratory, has presently as members J. Dow, C. Flym, A. Kunz, and M. Salamon of Physics: H. Fraser and E. N. Pugh of Metallurgy; J. Holder of Geology; J. Jonas (Chsitman) of Chem1stry; and $G$. Wirtz of Ceranic Bngineering. In addition to these comittees, Laboratory activities are assisted by comittees for equipment acquisition, the central facilities, health 
and safecy, and ad hoc program cominttees for scrutiny of opportunities and direction of the Laboratory's research. These comittees are an effective thethod for promoting interaction between the Laboratory members.

A most important function of the Laboratory is the provision of central facilities for the support of research programs. The major facilities include the Chemical Analytical Laboratory staffed by fout professional enployees; the Microstructure Facility (transmigsion electron mitcroscopy, scanning electron microscopy, electronmicroprobe and scanning Auger spectrometer) staffed by two professional employees; the Conputer Facilicy (a Sigma $S$ time sharing system with a 96,000 word menory); and a Machlne Shop which employs nine machinists. The Laboratory also operates a Storeroom for sale of scientific and metal stock ftems. The use of these facllities is charged to the Laboratory research projects on a time or fob basis as approprtate.

In addition to the major centrat facillties, the Laboratory supports minor factlitles which, whlle of privary interest to small groups within the Laboratory, are available to all members. These minor factlities include the Optical Laboratory (Infrared, ulcraviolet and kaman spectrophotoneters), the Mechanical Test Laboratory (810 MTS system), the High Temperature Laboratory (vacuun furnaces and dilatometer), the Toxic Materials Laboratory, the Materials Preparation Laboratory (UHV systems primaxily for purification of niobium), and the cryogenics Laboratory (15 stations for cryostats and a helfum recovery system).

The primary support of the Labotatory's program is derived from the U. S.. Energy Research and Development Administration (Contract E(1I-1)-1198 and the National Science Foundation (Grant DAR-72-03026). 
Moterials Research Laboratory

University of Illinois

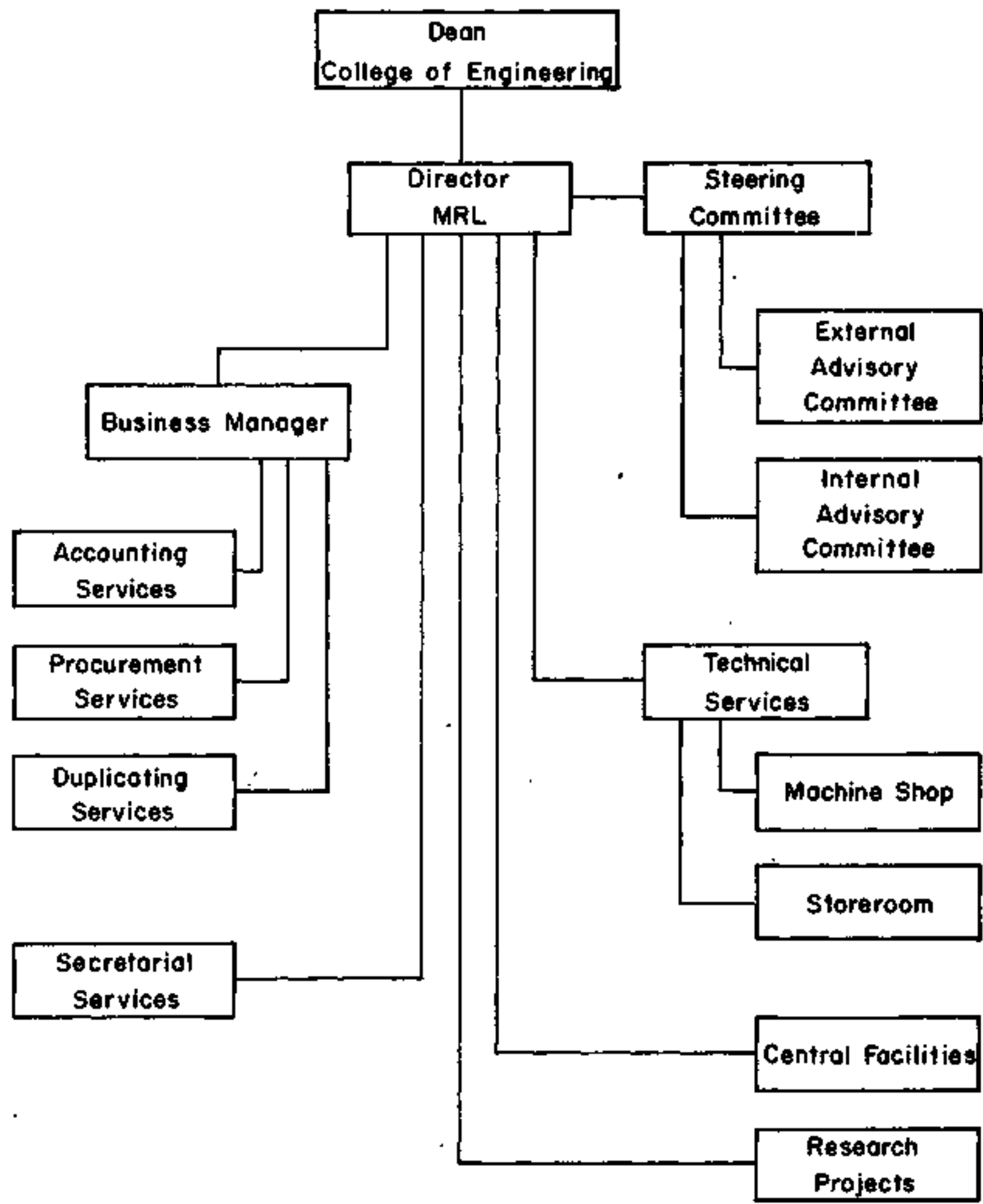


The operatfon of the Laboratory is asstated by the comnittees and factlities liated below:

Heal th and Safety

F. Wise, C. Evans, J. Stanley

Hachine and Faculty-Student Shop

F. Wise, H. Stapletion

Cheplcal Analytical Laboratory

C. Evans, G. DePasquali

Toxic Materials Laboratory.

S. Brown

High Temperature Laboratoty

S. Brown

Magnet Facility

F. Brown, C. P. Slichter

Materjals Test Laboratocy

C. Altstetter

Microstructure Laboratory (Electron Microscope, Electron Microprobe, Scanning Electron Microscope, Z-Ray. laboratory, and Metallograph Laboratory)

c. Wert, H, Fraser, J. Woodhouse

Crystal, Growth Laboratory

H. Birnbaum

Accelerator Laboracory ( $3 \mathrm{MEV}$ Van de Graaff)

J. Koebler

Cryogentc Laboratory

D. G1nsberg

Optical Laboratory (Uttraviolet, Infrared, and Ranan Spectrophotoneter)

M. Klein 
Computer Systen (Signa 5)

A. B. Kunz, H. J. Stapleton, V. Metze

Autocrol, Key Punches, Calculators, Typewricers

D. Ginsberg, J, Stanley

Reading Room

R. Maurer

Seminar

R. Maurer

The Professional Staff of the Laboratory are:

Chemical Analytical Laboratory

C. A. Evans, Ph,D., Senior Research Chemist and Associate Professor, Department of Chemistry

R, J, Blattner, M.S., Research Chenist

J. Baker, B.A., Research Chemist

P. WIlliams, Ph.D., Research Chemtst

Microstructure Eaboratory

3. Woodhouse, B.A., Research Microptobe Analyst

I. D. Ward, Research Metallurgist

Accelerator Laboratory

A. De1so, Accelerator Technician

B. Clymer, Accelerator Technician

Computer System (\$1gma 5)

V. Metze, Research Programmer

(also, part-t1me student operators are employed)

Mr. F. Wise, B.A., is Technical Services Superviosr with

responsibility for the Machine Shop and General Storetoom.

\section{Terminated Projects}

Paul A. Beck, Department of Metaliurgy and kining Engineering Electronic Structure and Magnetism of Transition Metal Alloys Supported by the U. S. Energy Research and Development Adninistration 


\section{New Projects}

David A. Payne, Ph.D., Assigtant Professor of Ceramic Englneering Dielectric Solids

Supported by the U, S. Energy Research and Development Adninistration

Awards and Honors

BECK, P.A., Department of Metallurgy and Mining Engineering Honorary Membersh1p, Hungarian Physical Soc1ety, 1975

Sauver Achievement Award, Anerfcan Society of Metals, 1976

EVANS, C. A., Department of Chemaistry

Scientif1c Membershlp, Bbhrische Physical Soc1ety, 1975

GRANATO, A. V., Department of Physics

Sr. U. S. Scientist - Hunboldt Auard, 1975

Leaves of Absence

None

Trayel

Paul A. Beck, Professor of Physical Metallurgy

August 19 - September 15, 1975 - Budapest, Hungary

Attended Second Specialized Colloque Ampere

Presented 1nvited talk on "Recent Developments in the Magnetism in Alloys" at a meeting of the Hungartan Physical Society and accepted an appofntment to honorary menbership in that Society

Vis1ted the Research Institute for Technical Physics of the Hungarian Acadeny of Sciences in Budapest

Total expenses charged to the contract $\$ 660.73$

Ralph 0. Simmons, Professor of Phystes Sep tember 7 - 17, 1975 - Juilch, Germany

Attended International Conference on Dynanics of Molecular Crystals, presented a paper "X-Ray Diffraction Studies of Methane $\mathrm{CH}_{4}$ Crystals" Visited Institutes in Stuttgart and Darmstadt

No cost to the ERDA contract

\section{Viaiting Staff Members}

M. Anano, National Research Institute of Metals, Tokyo, Japan, is a Visiting Research Associate Professor of Metallurgy, working with H. K. Birnbaum, September 1, 1975 through August 31, 1976. 
M. H, Loretto, University of Birninghan, England, was a Visiting Research Professor, Department of Metallurgy, May 21 - July 20, 1975 , working with $\mathrm{h}$. Praser.

Y. Lw1D, Northern Illinoig University at Hacomb, spent the summer as a Visiting Assoclate Professor of Physics, collaborating wtth the J. S. Koehler group.

Kazuhiro Otsuka, Jniversity of Tokyo, is a Visiting Research Assoctate Professor, Department of Metallurgy through March 4, 1976, working with C. M. Wayman.

\section{other Visicors}

Professor G. Leibfried, Jultch, Germany (presently at Oak Ridge National Laboratory), visited the Laboratory, gave a geminar, and discussed irradiation damage with the J. S, Koehler group Apri1 24-26, 1975.

Professor K. Shimizu, Institute of Sclence and Industrial Research, Osaka University, Japan, visited the Laboratory and consulted with C. M. Wayman, Msy 11-13, 1975 .

Dr. B, D. Nag-Chaudhuri, Vice Chancellor, J. Hehru University, New Delhi, India, visited the Laboratory, consulted with the Director, and gave two University seminars, May 12-15, 1975.

Professor L. Delaey, The Catholic Univers1ty of Leuven, Belgium, visited the Laboratory and consulted with C. M. Wayman, June 2-3, 1975.

Professor V1rich Franck, Institute fur Phys1k, Chente, Karlscuhe, W. Gernany, visited the Laboratory and consulted vith H, G. Drickamer on high pressure research, September 22 and $23,1975$.

J. V. Stebut, Centre d'Etudes Nucleaires de Fontenoy-aux-Roses, visited the Laboratory and consulted with the A. V. Granato group october 2 and 3,1975 .

R.G.J. Strens, Department of Geophysics, The University-Newcastle on Tyne, visited the Laboratory and discussed high pressure spectroscopy with H. G. Drtckamer, October 15-16, 1975.

John H, Sinfeld, Exxon Corporation Regearch Laborstory, Linden, Nev Jersey, visited the Laboratory, gave a seminar, and discussed catalysis with several nembers of the Laboratory, November 12-13, 1975.

Professor c, Ramasastry, Departnent of Physics, Ind1an Institute of Technology, Madras, India, visited the Laboratory and consulted with the D1rector, November $11-13,1975$

Professor Wolfgang hofer, Max Planck Institute fur P lasmaphysik, Garching, West Germany, visited the Laboratory, gave a seminar, and visited the C. A. Evans group October 30 and 31,1975 . 
Sentnars

HRL Symposium on Supertonic Conductors September 19, 1975

Far Infrared Dielectric Response of Beta Alumína

5. J. Allen, Bell Telephone Laboratories, Murray Hill

Ion-Ion Correlations and Diffusion In Beta Alumina

D. B. Mchhan, Be11 Telephone Laboratories, Murray Hill

Order-Disorder Transformation in $\mathrm{Rb} \mathrm{Ag}_{4} \mathrm{I}_{5}$

M. B. Salamon, University of Illinois, "utbana

Diffusion in Superionic Conductors

G. D. Mahan, Indiana Untversity, Bloonington

Surface Sciences Meeting

November $6-7,1975$

Optical Spectra of Adsorbate Atons

C. P. Flynn, Jniversity of Illinots, Urbana

Spectroscopic Studies of Chemforption and Chemical Feactions on Surfaces J. E. Demuth, IBM Corporation

Adsoxption and Catalysis by Metals: Surface Charactertzation Using

Photoelectron Spectroscopy and Electron Stimulated Desortpion

T. E. Madey, National Bureau of 'Standards

Electronlc Beam Analysis of the Electron Structure of Alloy Surfaces R. L. Bark, University of Maryland

Developing high Resolution, Solid state, NMR for Surface Sclence

R. W. Vaughn, California Institute of Technology

Adatoms on Metal Surfaces

W. Kohn, University of California

Effect of Physisorption and Chenlsorption

C. W. Woo, Northwestarn Jniversity

Cluster Studies of Surface Electronic Structure and Chenisotption K. 'H. Johnson, Nassachusetts Institute of Technology

Theory of Photo-desorption

N. Tzoax, City Unlversity of New York

Chemisorpcion Research at University of Chicago

L. Wharton, James Franck Institute

Effect of Alloying on the Mechanisms of Cacalysized Hydrocarbon Reaction on thetal Surface

G. A. Somorjai, University of Caljfornia 
Studies of Surface Reactions Using Molecular Bean and Auger Spectrometric Technique

J. B. Hudson, Renoselaer Polytechnic Inst1tute

Molecular Bean Studies of $\mathrm{Co} / \mathrm{H}_{2}$ Reaction on Cobalt and Nickel Surfaces D. A. Vroom, Intelcon Rad Tech ${ }^{2}$

Desorption of Products Formed by the Interaction of Methanol and Aluminum Oxide

J. M. White, Jniversity of Texas

Photo Catalycic Reaction

M. S. Wrighion, Massachusetts Inst1tute of Technology

Professor Tetsuro Suzukf, Department of Physics, Yokohama City Universicy, Yokohama, Japan

Martensitic Txansformations and Lattice Instabilities

Apr11 8, 1975

Professor P. A. Egelstaff, Department of Physics, University of Guelph, Ontar1o, Canada

Three Body Effects in Simple Flutds

April 9, 1975

Professor G. Leibfrled, Oak Ridge NationaI Laboratory (from Jullch, Gernany) Polarization of Point Defects

Apr11 25, 1975

Professor G. Fritsch, Technical University of Munich, Germany Measurements of Physical Properties of Sodium Near its Melting Temperature June 16,1975

Professor P. C. Gibbons, Princeton University

Electron Energy Loss Spectroscopy

August 8, 1975

Professor U1rich Franck, Institute fur Physik, Chemie, W, Germany

Properties of Fluids and FIuId Kixtures at High Pressure and High Temperature September 22, 1975

Dr. F. Dworschak, Julich, Gernany

Impurity Interstitial Interactions in $\mathrm{Cu}$ and $\mathrm{Al}$

October 15, 1975

Professor Lawrence Slifkin, Department of Physics, University of North Carolina, Durham

The Role of Ionic Surface Charge in the Photograph1c Process

october 24, 1975

Professor Wolfgang Hofer, Max Planck Institute fur Plasmaphysik, Garch1ng, w. Germany

Ion Microprobe Mass Spectronetry

October 31, 1975 
Dr. Jahn H. Sinfeld, Exxon Corporation Regearch Laboratory, L1nden, NJ Catalysid by Metals

November 12,1975

Professor A. Guinter, Laboratorle de Physique des Solfds, Universite Paris, Oraay

Some New Results in Preprecipitation Studies

November 19, 1975

Dr. Bernd Sonntag, DESY, Hamburg, Germany

Recent Results at DESY

January 8,1976 


\section{PROUECT TITLES AND PRIFCIPAL INVESTIGATORS}

METALLURGY AND CERAKICS

\section{ED-02-01-01-0 Structure of Materials}

Electronic Structure and Magnetisn of Transition Metal Alloys

Paul A. Beck, M.S., M.E., Professor of Phys1cal Metallurgy

Dynanfic Structure of Supercritical Dense Hater and Aqueous Electrolyte Solutions

Jiri Jonas, Ph.D., Professor of Chemistry

Solfd State Phase Transformations and Thin Filns

C. Marvin Wayman, Ph.D., Professor of Metallurgical Engineering

Physics of Refractory Materials

Wendell S. Whlliams, Fh.D., Professor of Physics, Ceramic

Engineering, and Bioengineering

ED-02-01-02-0 Mechanical Properties

Interstitial Solid Solutions

Carl J. Altstetter, Sc.D., Professor of Physical Metallurgy

Hydrogen Behavior in BCC Metals

- Howard K. Birnbaun, Ph.D., Professor of Physical Metallurgy

Applications of Electron Microscopy in Materials Science

Hanish L. Fraser, Ph.D., Assistant Professor of Metallurgy

Deformation of Reinforced Metals

Marvin Metzger, Ph.D., Professor of Physlcal Metallurgy

The Mechantsm of Stress-Corrosion Cracking: Propagation Studtes

E. Neville Pugh, Ph.D., Professor of ketallurgical Engineering

Precip1tation in Refractory Metal Alloys

Charles A. Wert, Ph,D., Professor of Physical Metallurgy;

Head, Departwent of Wetallurgy and Mining Engineer1ng

ED-02-01-03-0 Physical Properties

Dielectric Sol1ds

David A. Payne, Ph.D., Assistant Professor of Cerantc Engineering

Nuclear Magnet1c Resonance Studies

Theodore J. Rowland, Ph.D., Professor of Physical Metsllurgy 
SOLID STATE PAYSICS

ED-02-02-02-0 Experimental Research

Use of Very ligh Pressure to Investigate the Structure of Matter Harry G. Drickamer, Ph.D., Professor of Chmical Engineering and Physical Chemistry; Member, Center for Advanced Study

Anharmonic Rffects in Solids

Andrew v. Granato, Ph.D., Professor of Physics

Defect and Electronic Properties of Solids

David Lazarus, Ph.D., Professor of Physics

Properties of Noble Gas Crystals

R. O. Simmons, Ph.D., Professor of Physics; Head, Department of Physics

Nuclear Magnetic Resonance in Sollds Charles P, slichter, Ph.D., Professor of Physica;

Menber, Center for Advanced Study

ED-02-02-04-0 Particle-solid Interactions

Radiation Danage in Solida

Janes S. Koehler, Ph.D., Professor of Physics 
ED-02-01- $00-0$ GETALLURGY AND CERAMICS SUMQMARY

The Hetallurgy and Cerantes program of the Laboratory is focussed on the following areas of investigation:

2. The mechanical properties, strength, and fracture of refractory metals, alloys and transition metal compounds. A major collaborative effort exists to understand the effect of gases and light interstitial elements on the properties of niobium, tantalum and vanadium. Euphasis is on the mobility of interstitial solutes like hydrogen, the nechanism of hydrogen enbrittlement and fracture In alloys, the precipitation of dispersed phases of hydrides, carbides, nitrides and oxides and the effect of these phases on mechantcal properties. An attempt is being wade to understand the role of Interface parameters in determining the strength of metal matrix-metal fiber and lamellar composite materials.

An understanding is sought of the relationship between the electronic and defect structures of transition netal compounds, like tungsten carbide, and their great hardness, strength, and catalytic properties. Energetic ion sputtering of refractory metal surfaces, a topic of importance for Future fusion reactor dasign, is also being investigated.

These studies are motivated by the importance of improved structural materials that are necessary for apptications under extrene temperature and environmental conditions for coal gasiffcation systems, energy systems involving pipeline trangmission of gases containing $\mathrm{H}_{2}$ or $\mathrm{H}_{2} \mathrm{~S}$, posstble energy storage in the form of hydrides and fission and fusion reactor applications. 
2. The dynamic structure of water and its electrolyte solutions under extreme conotitions of temperature and pressure is being determined. A byproduct of this research will be information concerning the corrosion of metals under extreme conditions, In conjunction with this research, the relationship between the 'structure of passive filns on metals and alloys and the mechanism of their corrosion under conditions of fluid flow and particle erosion will be investigated. The motivation of this research is its usefulness for the materials problems of geothermad energy utilization, dealination technology, and reactor systems. The feasibility of a practical isotope separation process for ${ }^{6} \mathrm{~L}, \mathrm{I}_{-}^{7} \mathrm{LI}$, using a high temperature, high pressure electrolyte system, will be deterained.

3. The electronic and defect properties of oxides, lite the La-Co-O system, are being explored from the perspective of their potential applications to catalysis, fuel cells and solar energy. New piezo and pyroelectronic dielectrics are belng synthesized and their properties determined in an effort to extend the capabilities of these waterials as therwal sensors and electric generators. Present materials have unfortunate low temperature ilnits.

4. The magnetic properties of the mictonagnet1c (spin glass) systems of $3 d$ transition element metal alloys have been investlgated in a program terminating with FY76 because of the retirement of the principal 1nvestigator, Frofessor Paul Beck.

A wide range of expertwents have been concluded in alloys of refractory metals. They include confirmation of quantum uechanical tunneling in diffusion of hydrogen in wo. This experiment by the group 
working with Professor H. Birnbatm pxovides verification of the diffusion theory of Professor C. P, Flym and Dr. A. Stoneham, The solubility and chemical potential of oxygen in vanadium has been determined by Professor C. Altstetter. Mechanisms of control of alloying elements $\mathrm{K}$, Al and S1 during fabrication of tungsten filaments has been deternined by Professor $C$. Wert in collaboration with a research team from Westinghouse. These elements produce arrays of potassfum-filled volds during recrystal11zation which inprove the creep resfstance of tungsten. The formation of $\mathrm{V}_{2} \mathrm{H}$ in vanadiun has been shown by Professor $M$. Wayman to be similar to a conventional martensitic transformation in habit plane, orientation relationship and lattice strain.

Stress cotrosion cracking of alloys of magnesium and aluminum has been found by Professor E. N. Pugh to have many similarities to fracture in refractory metals containing hydrogen. Fracture surfaces, both 1ntergranular and tranggranular, conta1n a brittle layer of magnestum hydride. Formation of these stress-induced hydrides is stmilar to the process of fracture in nlobium contalning bydrogen found earlier by students of Birnbaum. Futther, fracture in a Ti-Al-ko-V alloy has been shown to be caused by fornation of . titanium hydride. The hydrogen appears to enter in the $\beta$-phase and forms the brittle hydride in the $\alpha$-phase at the $\alpha-\beta$ interface.

Age hardening in Cu-Be alloys has been shown by Professor T. Rowland to proceed with the initial formation of coherent precipitates of the compound CuBe which are so suall that they have not been detected by electron nicroscope techniques.

Stacking faults in silicon have been shown by Professor H. Fraser to peruit displacement of $\mathrm{Si}$ atots by energetic electrons with energies 
signiffcantly smaller than expected. Professor Metzger has shown that the watrix resnforc1ng phase interaction in netal composites is dominated by interface strain conpatiblitty requirements. Stress strain behavior and ductility dependence on tenperature were controlled by the avaflabtlity of slip modes that met this constraint.

Theoretical calculation of Professor W. Williams and his coworkers of energy levels and electronic wave functions have revealed significant clues to the slmultaneous extstence of great hardness and metallic conductivity in the transition taetal carbides.

The self-diffuston coefficient of the proton and deuteron in water has been determined by Professor $\mathrm{J}$. Jonas from $10^{\circ} \mathrm{C}$ to $200^{\circ} \mathrm{C}$ and from 1 to $10 \mathrm{kbar}$. Apparatus to extend the measurenents to $850 \mathrm{~K}$ has been const ructed.

In the process of synthesizing plezoelectric and pyroelectric ceramics, Professor D. Payne has discovered that the use of $\mathrm{Pb}_{5}(\mathrm{Ge}, 51)_{3} \mathrm{O}_{11}$ as a liquid wetting agent for the sintering of $\mathrm{BaTHO}_{3}-\mathrm{Pb}_{5} \mathrm{Ge}_{3} \mathrm{O}_{11}$ ceramics reduces the sintering temperature from $1400^{\circ} \mathrm{C}$ to $750^{\circ} \mathrm{C}$ with both energy and precious metal conservation over previous procedures.

Emphasis during the coming year will continue to be placed on problems of hydrogen diffusion in the refractory metals and the mechanisn and property changes assoclated with hydride precipitation. Experiments on hydride precipitation in $\mathrm{Hb}-\mathrm{H}$ will be extended to Include spinotdal deconposition at the niscibility gap. Different aspects of this work wll1 be carried out cooperatively by Professors H. Birnbaum, H. Fraser, T. Rowland, H. Pugh, and A, Granato, The new abjd importatit project of the extension of the research of hydrogen mobility in the refractory 
metals to the Iavestigation of helium mobility will be begun.

The investigation of oxygen-solute interactions in v-kb-a systens will be completed by Professor $c$. Altstetter during the next year. An attempt will be made by Professor $C$. Wert to obtatn high temperature strengthening of $\mathrm{V}-\mathrm{Nb}-\mathrm{Ti}-\mathrm{Cr}$ alloys through prectpttacion of subricron coherent particles of mixed carbides. Stabillty ranges of these particles will be determined.

The Investigation of stress corrosion cracking of Mg-Al alloys will be extended by Professor N. Pugh to Include the Mg-Al-Zn alloys. In cooperation with Professor H. Fraser he will also examine the effect of lodine on the fracture of $\mathrm{zr}$ alloys-a problem of Interest because of the effect of lodine Eission fragments on the properties of Zircalloy fuel cladding of nuclear resctors. Stress corrosion crscking of titaniun will be investigated by Professor R. Alkire.

Professor M. Metzger's studies of composites will concentrate on the relationship between flow stress and interlamellar spacing in

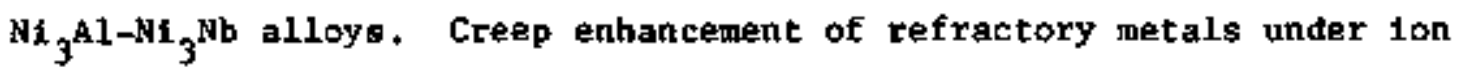
Irradiation will be examlned by Professor C. Altstetcer.

Professor $W$. Williams' studfes of the transition metal carbides will concentrate on the catlytlc activity of tungsten carbide surfaces in the oxidation of hydrogen in fuel cells. The dependence of catalytic activity on lattice and surface defects (carben vacancies) is a primary topic for study.

The research on oxides and dielectric solids of Professor G. Wirtz and D. Payne will concentrate on hydrothermal growth of $\mathrm{Bi}_{2} \mathrm{WO}_{6}$, sintexing of the $\mathrm{BaTiO}_{3}-\mathrm{PbGe}_{3} \mathrm{O}_{11}$ systen, evaluation of these and similar compounds 
like $\mathrm{Ba}_{2} \mathrm{TISI}_{2} \mathrm{O}_{8}$ and $\mathrm{PbTiO}_{3}$ for favorable piezo and pyroelectric properties, growth of $\mathrm{Tl}_{2} \mathrm{O}_{3}, \mathrm{LaCOO}_{3}$ and $\mathrm{LaCoO}_{4}$ crystals, the obtaining of pertinent phase equilibrium information and the determination of data needed to evaluate potential usefulness of $\mathrm{LaCoO}_{3}$ for the oxidation of $\mathrm{Co}$ to $\mathrm{CO}_{2}$ by sater with the production of hydrogen and the usefulness of oxide f1lme to iaprove solar energy collectors through an enhanced "greentouse" effect.

The experiments on the structure of water at high texperature and pressures vill be extended to $850^{\circ} \mathrm{C}$ and include measurements on LICl dissolved in supercritical compressed steam. If the data obtained indicate feasibility, a small systed for separation of ${ }^{6} \mathrm{Li}$ and ${ }^{7} \mathrm{~L}$ isotopes will be constructed. In parallel with the votk on electrolyte solutions, the structure of dfsordered "plastic" organle solids and palyners will be examined.

The progran on corrosion of Professor R. Alkire will be initiated with an investigation of the effect of fluid wechanlcs on the breakdown of passive layers through particle fropaction and cavitation. The expertments w11 study the effect of controlled Impaction as a function of surface shape and electrochenistry. An attempt will be made to explain the dissolution of foreign sulfide inclusions in passive surfaces. 
ED-02-01-01-0 Structure of Materials

Electronic Structure and Marnet 1sm of Transition Metal Alloy

Frincipal Investigator: PauI A. Beck, M.S., M.E.

Profestor of Phyglcal Metaliurgy

Supporting Agency: U. S. Bnergy Regearch and Development Administration

Sentor staff: Paul A, Back, Profeasor

Junior Staff: Robert D. Shull, Resesrch Assistant

Randa1 W. Tustison, Research Assistant

Object: This project has had the specific goal of a better understanding of the magnetic properties of alloys of the $3 d$ transition metals and a general objective of contributing to our knowledge of magnetism. Research efforts have euphsalzed the effect of the local atonic environment on the asgnetic nonent agooclated wth a $3 d$ netsl aton and the nagnetic structure of wictonagnetic or "spin g1sga" alloys. Thege alloys occur more comonly then has bees aupected among atonically disordered solid solutions. The basic research of the project is relevant to the effictent use of electrical energy devices 1ncluding motors, generators, and transformers and has inlications for the development of computer memories.

Results, FY 76: It has been found that the low alternating field susceptibility $8 \mathrm{t}$ the temperature of the cusp of $\mathrm{Cu}_{75} \mathrm{Mn}_{25}$ is $\mathrm{B}$ ignificantly decreased by severe plastic deformation and that the steady field suscepttbility in the temperature range of $140-300 \mathrm{~K}$ can be accurately fitted to the formula $x=x_{0}+c /(T-6)$. Following Kouvel [J. S. Kouvel, J. Phys. Chen. Solidg 21,57 (1961)]; the value obtained for C was Interpreted on a wodel 1nvolving compensation in the deforned alloy of about $50 \%$ of the Mn atomic monents by mesng of antiferromagnetic interaction between the sping on nearest neighbor Hn atons, as conpared with compensation of only about $25 \%$ of the Mn atomlc monents for the same alloy in the quenched state. Hew measurements on severely cold-worked alloys $\mathrm{Cu}_{50} \mathrm{Mn}_{50}, \mathrm{Cu}_{40}^{\mathrm{kn}} 60$, and $\mathrm{Cu}_{34} \mathrm{Km}_{66}$ indicate that increasing the Hn content further increges the Iraction of Mn atomg with apins coupensated. The reaults also show that $x_{0}$ 1ncreases with the concentration of compensated in noments, but that the wictomagnetlc freezing temperature, $T_{f}$, which has a maximkin at -40 at . 7 th, is directly related to the concentration of ucoupensated in moments.

The Fe-Al alloys with 25 to 32 at. $\%$ Al, ordered to the Fe $3^{A l}$ structure, have very unueual magnetic properties. It was found that the alloys with 28.5 to $30 \mathrm{z} \mathrm{Al}$, which axe ferromagnetic at room temperature, becone mictonagnetic on cooling to -70 to $90 \mathrm{~K}$. Alloys with 30.5 to $45 \% \mathrm{Al}$, which are paramagetic at room temperature, also becone nictonagnetic on cooling. The wfetomginetic freezlng cemperature, $T_{f}$, decreases wth increasing al content. 
Results Expected, FY 77: Support for this project will terminate with FY 76 because of the retfrement of the princlpal Investigator, Professor Paul Beck.

Relationshlp to Other Federally Punded Projects: The research is carried put vith detalied attention to the large anount of vork on magnet ic systems, particularly in the ERDA national laboratortes. Collaboration has existed, also, with the work at the von Laue-Langevin Institute at Grenob1e, Frapce with tnvestigators at Strasbourg, France, Amsterdan, Holland and VCLA, Los Angeles. Reciprocally, the importance of the profect's work has been recognized by athers through the election of the principal 1nvestigator to membership in the Hungarlan Physical Socfecy In 1974, the recelpt of the Hume-Rothefy Award of the Metallurgical Society of the AIME In 1974 and the recelpt of the 1976 Sauveur Award of the ASH.

Fublicat1ons: (Calendar Year 1975)

Paul A. Beck and C. P. Flynn

Interpretation of the Susceptibility of Paramagnetic Nickel

Sol1d State Cotmon. 18, 127-130 (1975)

Algo supported by NSF

A. Mukhopadhyay, R. D. Shu1l, and Paul A. Beck

Relaxation and Magnetic Cluaters In Mictonagnetic Cu-Ma Alloys

$J$. Less Common Metals 43, 69-82 (1975)

Also supported by NSF GH-37568X and JLCM 43(1975)69-82

R, D. Shull and Paul A, Beck

Mictomagnetic to Ferromagnetic Transition in Cr-Fe Alloys

AIP Conf. Proc. $24,95-96$ (1975)

M.S. Theses: (Calendar Year 1975)

None

Ph,D. Theses: (Calendar Year 1975)

None 
Dynamic Structure of Supercritical Dense Water and Aqueous Electrolyte Solutions

Princtpal Investigator: Jiri Jonas, Ph.D.

Professor of Physical and Analytical Chemistry

Supporting Agency: U. S. Energy Research and Development Adninistration

Sencor Staff: Jir1 Jonas, Professor

John W. LInowskI, Research Assoctate (Term 1/31/76)

Juntor Staff: Michael A. Fury, Research Ass1stant

Object: A study of the dynamic structure of vartous materials under extrene conditlons of high pressure and temperature represents the main thene of our research. Our interests currently focus on investigating molecular nottons, transport properties, and interactions at molecular level in compressed superertitical water, heavy water and compressed supercritical aqueous electrolyte solutions. In addition, we are also studylng varlous organic solfds with high degxee of reorlentational disorder and aeveral spectific polymerlc systems. The Isprovement of our understanding of the dynamic structure of the above materlals is of both theoretical and practical sf goificance.

The wain technlques we currently use are the nuclear magnetic relaxation measureuents and MR self-diffuston measuretrents. The MMR spectroscopy provides a powerful tool for investigation of molecular motlons and interactions at molecular level. One can obtain angular position and angular momentum correlation times for single trolecules, and from the neasured self-diffusion coefficlent via the spin echo fleld gradient cechnique, one learns about behavior of 1tnear mowentw in flulds. The capability of high resolution MMR spectroscopy via the Fourfer transform approach represents an inportant, unique feature of our experimental setup. In arder to extend the information content of our studies, we have recently started using laser Raman spectrascopy to obtain the time dependence of the correlation functions which characterize in detail the motions at the nolecular level. In the last several yearg we galned considerable expertise in high pressure, high temperature MR techniques, and as far as our current instrumentation is concerned, there is no other laboratory in the USA and/or abroad with the comparable performance features of the Mar experimental systes. 
Due to our recent progress 1n NMR 1nstrumentation for work at high pressire and high temperature, we are in a position to study the behavior of compressed water, heavy water and aqueous electrolytes well above its crftical temperature. Compressed supercritlcal water exhlbits a number of very interesting properties. The highly compressed supercritical water exhibits typical liquid properties but it has unusually high fluidfty and conductivity. It 18 worth emphasizing that the conductance of water at high pressure and high temperature nears that of concentrated alkelf salt solutions. Similsrly, under these extreme conditions strong electrolytes way be assoctated to form lon pairs and then behave as weak electrolytes. We plan to study the detalls of molecular mottons and transport properties in supercritical dense flulds and explain theoretically thetr unusual behavior.

There are a number of practical aspects to our experiments highly relevart to ERDA's practical energy wission. There has been an tsotope enrichment process proposed using high-pressure supercritical steam as a medium for disgolving lonfzable inorganic salts and then using the steam golution In an electrolytic cell with countercurrent flow. The effictency of the' 1sotope separation is considerably enhanced then superheated compressed steam is used as a solvent medium. This process is under consideration and evaluation by the Oak Ridge National Laboratory. S1nce the wajor problem in the electromagnetic separation of isotopes is the need for handling large quantitles of feed materlals with unneeded 1sotopes, even only a preenriching, relatively inexpensive process would be highly desirable. We intend to carry out a theoretical feasibiity atudy for this isotope separation process and if proved encouraging, we shall build a 1aboratory setup to show the practicality of such an approach. In our planned experiments we shall concentrate on ${ }^{6} \mathrm{~L} 1$ and ${ }^{7} \mathrm{~L} 1$ isotopes for the following reason. Lithiun is used in the primary reactor cooling systems of pressurized water reactors. Highly enriched ${ }^{7} \mathrm{LI}$ is desirable since it converts to nonradioactive hellum upon neutron capture whereas ${ }^{6} \mathrm{~L} 1$ converts to tritium. If our experiments on 1 ithith prove successful, then we may attenpt a thore difficult separation of the isotopes of uraniun.

One should also tention some other practical aspects of our experiments which have direct relevance to non-nuclear energy sources. Better knowledge of the properties of water and aqueous electrolytes at high temperatures and high pressures w111 contribute to the solution of practical problews related to e.8. powet generation by steam turbines, geothermal energy utflization, evaluation of certain proposals for underground poter production, desalination technology. There is one additional practical aspect of our studies. Supercritical dense aqueous electrolytes are highly corrosive and therefore, during our experiments, we shall gain valuable expert18e about corrosion of varlous naterials under extrene conditions of temperature' and pressure.

Another aspect of our research activity is the lavestigation of the dyanic itructure of disordered organic solids which exhlbit a high degree of reortentational disorder. The gosl of these experiments is to learn about diffusion in these disordered naterials, and, in particular, to improve our understanding of order-disorder transitions. Out recent experiments on 
several so-called plastic crystals indicated that WMR relaxstion exper1ments both In the laboratory and rotating coordinate frames are well-sulted to study the neture of thege order-disorder transtitions. The use of pressure as an experimental variable in studying these disordered waterials greatly Increases the information content of the MMR experiments. We plan to interpret our exper1ments in terms of avsilable theoretical models with spectsl emphasis on hysteresis phenomena accompanying these order-disorder transitions. The results will be of importance for theoretical understanding of the important phenomenon of order-disorder transition which is relevant to development of better englpeering materials. Slnce future electronic devices may be based on organtc solids, this fact repregents another longrange practical aspect of our experiments.

Another class of materlals under study ate vartous polymertc naterials e.g., polytetrafluoroethylene, polyanides, polyethylene. We plan to investigate molecular wotions in these polymeric matertals using the techniques described above. Since many practical uses of polymers Involve the presence of mechanical forces, our experiments directly relate to the problem of the structure of polymers and the1r mechentcal properties. of particuzar interest are polymers which are used as solid lubricants and hfgh temperature polytaers. Dur studles w11l help to answer questions such as: What 1 s the molecular structural basis and dynamic phenomena deteraining the use for particular polymer as a solid lubricant; what is the high temperature limit of practical uses of special high temperature polymers when under mechanical stress and what is the molecular basis for this behavior? Our resutts will be useful for laboratorieg developing new types of polymeric materials.

Results, FY 76:

Most Significant Accomplishments: The self-diffusion coefficients, the proton and deuteron NR spin-1atcice relaxation tfmes in water and heavy water were measured as a function of pressure and cesperature in the range $10^{\circ} \mathrm{C}$ to $200^{\circ} \mathrm{C}$ and $1-10 \mathrm{kbar}$.

Analysis of our experimental MR relaxacion data leads to several important conclustons about the motional behavior of water molecules in compressed liquid water and heavy water. First, the 1nitial increase in density at low temperatures produces a faster reorientation of the water molecules. This is eastly understood in terms of a simple physfcal picture. Since reorientation of water molecules mist proceed via breaking and reforming of bydrogen bonds, one can readily see that high compression which d1storts, disrupts, and generally changes the optimal tetrahedral hydrogen bond network will facilitate such reorientational pracesses. Second, cotpression results in a decreased coupling between the rotational and translational motions as reflected in the relationship between the reorientatlonal correlation time of water molecules and shear viscosity. Therefore, the Debye equation falls to degcribe the effect of density on the reorientation of water molecules. Third, we find that the activation. 
energles for reluxation, self-diffuston and shear viscosity decrease with increasing density, again reflecting the changes in hydrogen bonding upon compression. From these fludings we concluded that compression of water produces major changes in the randon hydrogen bond network with the result that water begins to behave more as a "normal" liquid under high compression. Our expertuental results are in agreement with recent molecular dynamics calculations on water by Stilinger and Rahman (8el1 Telephone Lab., Argonne National Laboratory). In a general sense, the results of these studies can be regarded as a good illustration of the importance of using press ure as an experimental varlable 1n studies of the dynamic structure of Ilquids. The results of these studies will be published in a serles of articles in the JOURNAL OF CHEMICAL PHYSICS.

Other Results: (1) As a fixst stage of our work on supercritical coapressed water, we built and tested an Internaliy-heated, argon pressurized NMR probe which enables us to reach tenperatures of $850^{\circ} \mathrm{X}$ and pressures up to $2 \mathrm{kbar}$, WMR relaxation and diffusion measurements are $1 \mathrm{~s}$ progress.

(2) In continuation of our atudies of applicabllity of hydrodynamic equations at molecular level, we Investigated the applicability of the Debye equation which gives the relationship between the reorientational correlation tiae and shear viscosity. Similarly, as we found earlier for the Stokes-Einstein equation, a modified Debye equation well represents our experinental data on polyatomic molecular fluids.

(3) Using the Fourier transfort technique, we obtained unique information about the dependence of the proton chemlcal shift in water upon density and temperature. A special coaxtal sample cell for an external standard which permits measurements at high pressures was developed. The behavior of the proton chenical shift in water with density is in agreement with our other results for water as mentloned above. At low temperatures below - $30^{\circ} \mathrm{C}$ the Increased density disrupts the well-developed hydrogen bond network. At high densities the hard core repulsive interactions begin to dominate over the directional interactions which are mainly responsible for the open structure of liquid water at low temperatures and pressures.

(4) In order to 1nvestigate diffusion and slov notfonal processes in digordered organts sollds and polymers, we developed instrumentation for the NWR relaxation experiments in the rotating coordinate frames. An exploratory study of a molecular organic solid of cyclohexane was fintshed.

(5) We have started a theoretical feasibility atudy of the countercurcent flow electrolytic process for separation of lsotopes using high pressure supercritical water as a solvent wedtum for lonizable salts.

Reaulta Expected, FY 77; We expect to complete our experimental work on water and hesvy water up to temperatures of $850 \mathrm{k}$ and analyze the MRR relsxation and diffusion dota. The large increase in the lonic product of water at high cemperatures and pressures, the question of the extent of hydrogen bonding under these experinental conditions are a few of the many interesting problens we hope to explain on the basis of our experimental 
daca. We predict that at high temperature and pressure the hard core repulstve Interactions between the water molecules dotinate over the highly directional forces due to hydrogen bonding. It is likely chat the modified Easkog theory which forma a basis for the hard sphere model of fluids may prove successful in interpretation of the experimental data.

At the same time, measurements of LiCl dissolved in supercritical compressed stean should also be completed. The nature of hydration of lons and the extent of ion pafring under these extrene conditions are maln goals of our investigation. Additional salts such as $\mathrm{KCl}, \mathrm{HaCl}, \mathrm{CaCl}_{2}, \mathrm{CaCl}_{1} \mathrm{CaCl}_{3}$ dissolved in water and/or heavy water w1ll also be studied in the supercrittcal dense regton. Effects of varlous types of lons on transport properties of lons and water nolecules, and on the dynamic structure of these electrolytic solutions vill be followed. We expect that the results of these experiments will be interesting and valuable to the extent to justify further instrumentation effort to develop equipment which will allow us to extend our measurement $\mathrm{r}$ ange to temperatures in excess of $1200 \mathrm{~K}$ and pressures up to 5 - $10 \mathrm{kbar}$.

In the case that our theoretical feastbility study for the 1sotope separation process using superhested compressed stean as a solvent proves promising, we Intend to bulld a small scale laboratory setup to attempt the separation of ${ }^{7} \mathrm{~L} 1$ and ${ }^{6} \mathrm{LI}$ lsotopes. If our experinents on separation or enrichrent of 11thium leotopes are successful, we hope that the Oak Ridge Laboratory will further study the process or we shall extend our work to the separation of isotopes of urantum of mass 235 and 238 using uranium sulfate solutions.

Our preliminary results on the hysteresis effects accotpanying the orderdisorder transitions in organic solfds of adamantane, 2,2,2-b tcyclo-octane and hexamethyldisflane Indicated the possibility of using MMR relaxation measurewents to study the dynamics of an order-disorder transition, First, we plan to carry out detalled experiments on adanantane powders following the time dependence of formation of either the tecragonal brittle phase In the plastic phase or the reverse process by changing the extermal pressure at constant temperature. We also want to extend these experinents to single crystals and obtain information about antsotroplc interactions in these solids. We would like to carxy out both isothermal and 1sobarlc exper ments. We shall interpret our experimental data in terms of avallable theoretical models (for examle, models bast on compresstble Ising lattice) for order-disorder transition and plan direct collaboration and/or interaction with theorfats in the Materials Research Laboratory at the Uatversity of Illinols. In this connection we shall use the NRR relaxation experiment In the rotating coordinate frame to obtain information about the diffuaion mechanism in these disordered materials. We are interested in finding whether diffusion in these materials can be 1nterpreted in terms of a simple physical picture and to wat extent the detalled nolecular structure affects the diffusion mechantsw when going fron one molecular solid to another.

We have already carried out gome MMR relaxation experiments on polytetrafivoroethylene over a wide range of presaure and temperature. Our interest was focused on the dynamic structure of a h1gh pressure phase of polytetrafluoroethylene which was recently diacovered. So far our results were not 
conclusive and therefore we would like to use the NMR relaxation experiments In the rotating coordinate Erawe to charactexize the molecular motions in this high pressure phase of polytetrafluoroethylene. These studies are of high practlcal interegt because of the widespread use of teflon as a solid Iubricant with excellent frictional properties.

We would like to start our experimental work on NMR relaxation experiments on sollds using pressures up to 50 kbar. This project w1ll be carried out In direct collaboratlon with $H$. G. Brickamer, Professor of Chemical Engineering and Physteal Chemiatry.

Results Expected, FY 78: In 1978 we expect to continue our work in the three main areas: supercrittcal dense flulds, disordered sollds and polymerte materlals. The study of the dynamic structure of varlous electrolytes in the supercritical dense region should be completed during this pertod. We expect that the various observed phenomena of theoretical and practical interest will warrant extension of our studies in two dfrections, First, we would like to start experiments on ternary systens such as water-electrolyte-hydrocarbons; water-C0 ${ }_{2}$-electrolyte systems or amonia-water-electrolyte systems. Second, we would like to extend the upper temperature and pressure limit of our experiments to permit work on transport properties and dynanilc structure of fused salts. with current interest in the potential use of fused salts as heat transfer media in nuclear reactors, the laportance of 1mproving our understanding of these matertals fa quite obvious. We would like to systematically measure a number of fused salts, facluding, e.g., a study of transport propertles of $\mathrm{BeF}_{2}$.

In 1978 we expect to have avallable the equipuent for NMR relaxation experiments at pressures up to 50-100 kbar. Th1s opens many new directions of research. To name only one example--the study of the dynamic structure of a h1gh pressure phase of polyethylene and a systematic study of motional dynagles in varlous other polymerlc systems under high pressure.

Depending on the results of our MMR experiments on polymers, we may develop new instrumentation usting the Fourier transform techniques to measure WMR spectra of ${ }^{1{ }^{3} \mathrm{C}}$ at natural abundance in various polymers under h1gh tenperature and pressure. The bests for these expertments is the observation that narrow NMR lines are observed In the ${ }^{3} \mathrm{C}$ spectra of solid elastomers for temperatures abave the glass transition temperature. These ${ }^{13} \mathrm{C}$ lines are note than one order of magnitude narrower than proton NMR lines of the same system and are sufficiently narrow to permit resolution of the resonances of individual carbons. The abilicy to measure the relaxation times of each individual carbon w131 permit detalled evaluation of segnental motions in various polymers and characterize the relative signiftcance of thernal and volume effects on the dyaanics in these materials.

Relationship to other Federa11y Funded Projects: Since our high pressure, h1gh temperature experiments are unlque, thete is no duplication of our ef fort with laboratorles elgewhere in the USA and abroad. However, close contact 15 malstalned with NMR and high pressure regearch in other laboratorles . 
We plan to provide our data on superheated compressed steam and compressed supercritical aqueous electrolyte solutions to the Isotope Development Center at the Oak R1dge National Laboratory where feasibility of the 1sotope separation process based on tsing high pregsure supercritical eteam as a solvent for lonizable salts. is under consideration. In addition, if our small scale laboratory experiments dealing with separation of 1sotopes prove successful, we intend to develop a close working relationship with the Isotope Development Center at the Oak Ridge National Laboratory. If evaluation of the process at a practical scale is decided upon, we plan to assist with our expertise gained during our experiments.

In view of the fact that our work on supercritical compressed water and aqueous electrolytes is of high relevance for research on problens telated with aon-nuclear energy sources such as geothermal energy sources, and underground energy generation, we anticipate that our acudies will help laborator1es dealing with these inportant projects. Our expertise in behavior and properties of materfals at extreme conditions of high pressure and high tempersture may lead to a closer collaboration with some of these laboratories.

At the University of Illinois our interaction with $H$. G. Drtckamer, Professor of Chemical Bngineering and Fhysical Chemistry, is very valuable for our work. We plan several dfrect collaborat ive projects in the near future. The success of our laser Raman scattering experiments can be related to our Interaction with M. V. Klein, Professor of Physics, who is an expert in optlcal spectroscopy. Theoretical interpretation of our experimental results on order-diporder transitions and the hysteresis phenomena accompanying these transitions will require a collaborative effort with theoriots in the Department of Physics. Our current and proposed studies of polymers do not represent an 1solated effort at the University of Illinols becaue there are a number of researchers in the area of polymer engineering. A gtrong interaction with thio group is anticipated.

\section{Publications: (Calendar Year 1975)}

J. Jonas, T. DeFries, and D. J. Uilbur

Holecular Motions in Compresged L1quid Water

J. Chem. Phys. (In presa)

Also supported by ARPA DAMC 15-73-610 and AFOSR-75-3-0091

J. W. I,Inowsk1, Nan-I LIu and J. Jonas

The Effect of Densicy and Tenperature on the Hydroxyl Proton Chemical

Shift in L1quid Ethanol

J. Magrietic Resonance (in presi)

M.S. Theseg: (Calendar Year 1975)

None

Ph.D. Thege日: (Calendar Year 1975)

None 
Solid State Phase Transformstions and Thin Filns

Principal Investigator: C. Marvin Wayman, Ph.D.

Professor of Metrilurgics1 Engineering

Support1ng Agency: U. S. Energy Resear ch and Developtent Adnintstration

Sentor Staff: C. Marvin Wayman, Professor

Kazuhiro Otsuke. Visfting Resear ch Associate (Tern 3/4/76)

Junior Staff: Michael P, Cassidy, Research Assistant

Atef $H$. Eltoukhy, Research Assistant

Jun Ichl Fujlta, Research Assistant

Thoms E. Huspn, Research Ass1s tant

Myung-Hwan KIm, Research Ass1stant (Term 9/5/75)

Object: This work 1s centered around solid state phase transformations of

the martensitic type and focusses on a rumber of interrelated phenomena.

Studies of prenucleation and nucleation, mechanisws of growth, and

properties of martensitically formed phases are of concern. Pretransformation

phenonena, as recently found through work on this progran, are being studied

1n further detall by electron diffraction and nicroscopy. We are attempting

to understand apparent heterophase fluctuations which are revealed by

diffuse electron scattering and "streaming" effects in electron microscope

tuages. Related to this is a later stage of transformation where

instabilities in the regions of lattice imperfections promote the firet

detectable signs of phase nuclestion. Once nucleated, detalls of phase

growth are determined with particular reference to the nature of the

Interface between the two phases, and considerable progress has been made

In relating the observed dislocation structure of such 1nterfaces to a

probable growth mechanism, particularly in hydrides, The substructure of

the Einal phases is studied in order to perwit comparison between 1 t and

propertles of interest. For the most part, metallic hydrides and alloys

exhlb1ting thermoelastic martensitic transformations are being observed.

These are both of 1nterest in the energy scene. Hydrides are potentlal

materials for energy storage. Thermoslastic martensites usually exhlbit the strape memory behavior and thus offer promise for the conversion of low grade heat (cooling wastes, solar) Into mechanical energy. The emphasis is on fundamental research.

Results, FY 76:

Most Significant Accomplishments: Research on $\mathrm{V}_{2} \mathrm{H}$ has shown that the formation of this hydride is very almllar to that of conventional martensites. Electron wicroscopy has been employed to analyze the dislocations and their Burgers vectors aituated in the hydride-matrix 1nterface. From the Burgers vector and spacing of these dislocations, an 1nhonogereous shesr has been deduced, the magnitude of which is in remarkable agreement with the hab1t plane, orientation relationshp and shape strain, assuming the transformation to occur martensitically. The mechantstics of this type of transformation are beconing quite clear, and it remains to extend the work to other systems for generalization. 
Othey Results: Studies on the mechanical behavior of Cu-Al-Ni nartensites have shown a new mode of deformation. Whereas at low strains twin boundary notion within antensites occurs, and plates with preferred Schnid factors grow at the expense of others; at high otrains a new transformation to a different nartensitic structure occurs, 1,e., a martensite-to-martensite transformation. This behsvior is belleved to be typical of a nuber of thermoelastic martensites, and is capable of producing quite large strains (1.e., 20\%) which are fully recoverable when the applied stress is released. This new type of deformation behevior (frow $\gamma_{1}$, to $B_{1}$, in Cu-Al-Ni alloys) has also been found in Cu-Zn alloys, in which case the crystal structure of the final phase is now under investigation.

Additionsl studies of $\mathrm{Cu}-\mathrm{A} 1-\mathrm{N} 1$ and $\mathrm{Cu}-\mathrm{Zn}$ martensites have shown that certain thermolastic maxtensites form by a mechenisth of 1nteroal faulting, the end result being a long perlod stacking structure of the 9R or loR type. Analysis has shown, and a theoretical model has been presented, to explain how fntertally faulted martensftes are capable of complete cryatallographic reversibility, and to explain poeudoelastic and shape nemory behavior. It was previously considered that such faulted martensitic phases resemble slipped crystals and cannot exhtbit reversibllity. However, the additional presence of crystallographtc ordering presents strong restrictions on slip and faulting, and requires an Inverse deformation which lmparts the observed reverstbility.

Continued atudies of pretransformation lattice instabilities in several copper alloys by electron microscopy have demonstrated that a pronounced temperature effect exists. Diffuse electron scattering and Image instability become more marked at lower temperstures. This is exactly as expected. However certain "electron stimulation" snonalles have been found even In dummy materials such as pure copper whtch do not undergo any phase transforwation, and this observation is being pursued.

Studies of the thermodynamics of thermolestic martensites have shown that In the first approximation "engine effictencles" of the shape memory effect may be as high as $20 \%$. Thls analysis depends on an accurate delineation of two "characteristic" temperatures assoctated with a thermoelastlc martensitic transformation. The first of these is the $T_{0}$, the temperature where the chentcal free energieg of the two phases are equal, end the other Is a $T_{0}^{\prime}$ temperature, which is the former temperature, $T_{0}$, modifled by the prebsence of accumulated elastic energy. Theoretical work has continued to establish the fixing of these temperatures for a given transformation and to determining the magnitude of the stored elastic energy.

Regults Expected, FY 77: This research will be supported by the National Sclence Foundation beginning July 1, 1976. 
Relationshlp to 0ther Federally Funded Projects: Research on the formation of hydrides in metals has involved a study of the vanadium hydrogen system, and In the near future w11l be extended to the zirconlum-hydrogen system. This wotk is in collsboration with Professor T. E. Scott of the Ames Laboratory and Professor J. S. Bowles of the University of New South Wales. Efforta at the University of Ilitnols are centered on electron microscopy and diffraction gtudies. The Ames group is concerned with hydrogen charging, and specimen preparation, analysis and characterization. The work at the University of New South Wales focuses on $x$-ray crystallography, netallography, and Kossel line techniques. Work on martensitic transforuations is related to that sponsored by the National Science Foundation on Shape Memory Alloys. A part of the present research on pretransformation lattice Instabilities is in collaboration with Professor 5 . C. Moss at the Und versity of Houston. Whereas the Illinols efforts involve purely electron mecroscopy and diffraction techniques, parallel efforts on Cu alloys Involving nevtron diffraction measurements are being carried out by Professior Moss and the Brookhaven group during the sumer months, Work here on thermoelagtic martensites is related to the engineering and design research on witinol englnes at the Lawrence Berkeley Laboratortes. Cooperative aspects of the above prograns will be continued. Information Is exchenged wekkly at a seminar devoted to martensitic transformations. and related aspects, Met. E. 494.

Fubl1cat1ons: (Calendar Year 1975)

T. P. Darby and C. M. Wayman

Growth of Gold Thin E1lm Dendrites on Graphite Substrates

J. Cryst, Growth 29, 98-108 (1975)

T. P, Darby and C, M. Wayuan

Nucleation and Growth of Gold Films on Craphite I: Effects of Substrate Cond1tion and Evaporation Rate

J. Cryst. Growth 28, 41-52 (1975)

K. Otsuka and C. M. Wayman

On the shape Memory Effect in Internally Faulted Martensites

Scripts Met. 9, 1017-1022 (1975)

H. C. Tong and C. M. Wayman

Thermodynamle Considerations of 'Solsd State Englnes' Based on Thermoelastic Martensit1c Transformations and the Shape Memory Effect

Metallurgica1 Transactions 6A, 29-32 (1975)

Also supported by MSF 
H, C, Tong and C. M. Woyman

Therwodynamics of Thermbelastic Martenatic Transformations

Acta Metall. 23, 209-215 (1975)

Also supported by ARO (Durhan)

C. M. Wayman

Deformation, Mechanisns and Other Characteriatics of Shape Memory Alloys

Shape Kemory Effects in Alloys, edited by J. Perkins (Plenum Pub. Co., New York, $197 \overline{5}$, Pp. 1-28

Also supported by ARO(D) and NSF

C. M. Wayman

Shear Transformations and Microstructure

Metallography $\mathrm{g}, 105-130$ (1975)

Also supported by ARO (Durham)

C. M. Wayuan and T, P. Darby

Nucleation and Growth of Gold Filns on Graphite II: The Effect of Substrate Temperature

J. Cryst. Growth $28,53-67$ (1975)

K. Otguka and C. M. Wayman

Pseudoelastictiy and Stress-Induced Martensit1c Transformations

Reviews on the Deformation Behavior of Materials (accepted)

M.S. Thes 1s: (Colendar Year 1975)

I. Cassidy (C, H. Waynan, Adviser)

An Electron Microscopy Study of the Substructure of B-Hydride In Varnadiun May 1975

Ph,D. Thesta: (Calendar Year 1975)

S. Chakravorty (C. M. Wayman, Adviser)

Crystallography of the Thermolastc Martensitic Transformation in NA-Al Alloys 1975 
Physicg of Refractory Materials

Principal Investigator: Wende11 s, Williams, Ph.D.
Professor of Physics, Ceramic Englneering,
and Bloenglueering

Supporting Agency: U. S. Energy Research and Development Administration

Sentar Staff: Wendell S. Willans, Professor

Dwight Jennigon, Research Assoclate

Junlor Staff: David L. Kle1n, Reaearch Asslatant

Marvin W. Johnson, Research Assistant

James R. Beth1n, Research Assistant

Gerald H. Yost., Research Assistant

Barbara Browning, NIH Fellow

Roger Johnson, NIH Fellow

object: The development of new energy technologies--coal gasification, FHE, fuel cells, breeder reactors, fuslon, solar devtces--will be limited by the perfornance of materfals under condttions of extreme temperature, stress, radiation, corroston and erosion. The scope of this project involves a wde-rangling sclentifte study of a spectete class of ceramic naterials possessing extrene values of hardneas, melting point, abrasion reststance, superconducting transitfon temperatures and low chemical reactivicy that might be matched to these extreme operating conditions.

When the research supported by th1s profect was 1nitlated several years ago in an Industrlal laboratory, there was modest Interest in 1mproved high-temperature materials in Industry and considerable though transient Interest in the defense agencles. W1th the advent of the energy crisis the need for such materlals becane more sexious and again was focused 1 a the civillan sector. During these years, a considerable body of fundamental knowledge about the ceramic naterials under study has been developed. It is the goal of this subproject to extend, refine and direct this knowledge in the light of recently-percelved energy needs.

The ceramic materials receiving particular attention in this project are the monocarbides of the transition metals of columns $I V, V$ and $V I$ of the periodic table, $\mathrm{T} t, \mathrm{Zr}, \mathrm{Hf}, \mathrm{V}, \mathrm{Nb}, \mathrm{Ta}$, and $\mathrm{W}$. These are sone of the so-called "refractory hard metals," a nane that suggests at once a oclentifle puzzle: how can metallic conductivity and great harness coexist in the same solid? The puzzle is further complicated by the characteristfcally ionlc (NaCl) crystal structure of most of these materials. It appears that the transition-metal carbides exhlbft features usually assoctated wh each of the three principal types of bonding studied in solid state phyalcs-netallic, covalent and 1onfc. A major objective during the study of these materials has been to determine whether the 
features of electronic conductivity, great hardness and crystal habit are Indeed characteristic of the naterials or wether they are controlled by impuritles or other defects. A conclusive answer to this question has been reached, though it includes an ironic twist. From calculations of the energy band structure, performed recently in this group, but agreeing qualitatively with most earlier calculations, it is clear that the transition metal carbides are seminetals. The density of states curves show no gap. When the vacancles are disorderec, as is usually the case, they contribute heavily to the electron scattering; however, this research has also shown that the resistivity of the carbides can be completely controlled by the defect structure. These materlals are non-stolchiometric, and the lack of stoichlowetry is exhibited In the form of carbon atom vacancles. When the vacancles are ordered as in $v_{6} C_{\ldots} \ldots$, as we have shown, the resistivity drops. For special applications, for example as lead-1as for current in a corrosive environment or at high temperatures in a fusion reactor, a refractory hard wetel inght be very useful.

Vacancieg scatter not only electrons but also phonons. This research effort has contributed to the analysis of the role of carbon vacancies in heat transport in the carbides, finding that at low temperatures the vacancy scattering is far less inportant than that due to phonons interacting with conduction electrons. At bigh temperatures, however, the vacancy scattering Ia signiflcant and can alter the thermal conductivity over a considerable range both from reduction of electron-vacancy acattering and from phononvacancy scattering. The increase in thermal conductivity due to electronic component in these netallic matertals is one of the reasons for the renewed interest in the advanced nuclear fuel, uranium carblde, a solid quite similar in physical properties and structure to the transition-metal carbides. With a wide range of vacancy population avallable without change in crystal structure, the carbides offer a design engineer a large range of values of conductivity for optimization.

In addition to transport of electrons and phonons in the carbides, this project has studied atom transport; in particular, the electromigration and chemical diffusion of carbon in nonstoichionetric titanium carbide. Becauge of the high vacancy concentration, the activation energy for diffusion of carbon represents exclusively the migration term, though this term is large ( $4.5 \mathrm{eV}$ ) due to the atrong covalent bonding.

Plastc deformation and distocation behavior in the carbides have also been given considerable attention in this project and will again become pronfinent as more structural applications are envisioned in energy technologies. During FY 76 a new effort was started on the influence of electric fields and adsorbed molecules on the measured surface hardness of ceranic materials. Various interesting but ill-understood results have been teported in the literature lndlcating that an applied electric field produces a reduction in hardness of seniconductors. We will duplicate the measurements and, if the results are confirmed, atteupt to provide an interpretation. The phenomenon is at the beart of the relationsh1p between electrontc structure and dislocation properties that has motfvated two of out recent Ph.D. thesls profects. Clarification of 
these matters would go far to explatn micro plastic deformation of hard naterials in temperature reglons where dislocation glide does not readily occur. Improved understanding of this matter might suggest ways of reducing the brittleness of these and other refractory materfals and thereby increase their utility for appllcations where light weight and high strength are required, as in energy-saving vehtcles and wind conversion.

The second new project launched during FY 76 is in 8 heavily-worked but 111 understood area, catalysis. Sfnce tungsten carbide, one of the carbide fantly under'study here, is the second best catalyst known after platinum for oxidation of hydrogen in the fuel cell by electrocatalysis, we have decided to apply the detailed knowledge of the materlal developed here to this, for us, new area to see if general 1deas or principles of catalysts can thereby be 1solated or tested. For example, there is reported to be a strong correlation between defect concentration (carbon vacancies) in WC and its catalytic activity. We intend to study this relation in more detall and test the hypothesis that pofnt defects are the stites of catalytic activfty on a surface. Another hypothesis to exanine 18 provided by the theoretical work of $A$. B. Kunz and others in the MRL: a metal catalyst must have a $4 \mathrm{~s}^{2}$ electronic configuration at the surface. We will study the difference in catalytic effectiveness of TIC and WC with reference to both these idess--the necessity for vacanctes and for a spectfic electronic structure.

Inasmuch as the behavior of ceramic materials is the unifying thene of this program, we have extended the study to include blological ceramics, especialiy teeth and bone.

The program of research carried on and projected for this prograw, though centered on materials rather than techniques, has developed expertise and equipment for mechanical testing in vacuun at high temperatures, $\mathrm{X}$-ray topographlc studies of dislocations, and high-tmpedence electrical measurements. Apparatus to be acquired during FY 76 wi11 allow measurenents of electrocatalytic activity and microhardness. In addition to these cechniques, the project wakes extensive use of the centrat factlities of the MRL, espectally the electron microscopes and the computer.

Result5, FY 76:

Most Significant Accomplishnents: The nost algnificant result obtained during $F Y 7 \overline{6}$ was the refinement of our understanding of the origin of otrong bonding in the refractory carbides, through the application of locsl orbitals techniques for solving the Hartree-Fock equation for solids. Thls work was conducted by a research assoclate (D. Jennison) who learned the computational techniques from Professor A. B. Kunz of the Illinols MRL. Since major potential use for these cerdmic materials is in structural parts for high-temperature applications (e.g., in turbines), a better fundamental understanding of the reletion between the electrontc 
structure of the solfd and 1 ts mechanical properties is required for optimizing the performance,

The calculationg show that there la gtrong covalent 1nteraction between the carbon $2 p$ states and the wetal $3 \mathrm{~d}$ and $2 \mathrm{~s}$ states. The resulting orbitals are directed and rigld, thus accounting qualitatively for the hard and brittle character of the materials. A small Madelung contribution to the energy 18 also found. The calculations done by this nethod are the nost rigorous and accurate yet attenpted for th1s class of solids with wixed binding character.

The electron energy bands have also been calculated for TiC with the local orbitsls apprōach. Whereas the general shape of the bands is $1 \mathrm{n}$ agreement with other calculatfons using APW gethods, the importance of the present result is that it is self-consistent and has no adjustable parameters or emplical 1nput. Thus this band structure should be a definitive one for the matertal studied.

Other Resultg: A related result from this effort, which is closely tied with Professor Kunz's group, is an approximate treatment of clusters of atons using a conputational scheme which is much faster than the unrestricted Hartree-Fock taethod. The cluster program is now essentially in finished form, and with it studieg can be made of defects and surfaces of these solids (see FY 77).

Another result obtalned duxing FY 76 is an interpretation of the temperature dependence of the residual resistivity of the nonstolchiometric carbides. In these sollds, as we have demonstrated (Ph.D. thesis by

- L. Shacklette, 1970), the carbon vacancies act as strong scattering centers for conduction electrons. Since the erystals are nonstolchiometric, there is a large vacancy population to provide the scattering centers. Low tempezature reaistivity measurements show an exceptionslly large realdual reatativity, but this quantity ls strongly tempersture-dependent, In diagreement with the efmple form of Matthiessen's rule. Although the residual realativity accounts for approxinately 50 micro-ohm $\mathrm{cm}$ at 1iquid helium temperature, it only contributes approximately one-tenth of that at $1000^{\circ} \mathrm{C}$. A curve of residual resistivity versus temperature for vanadium carbide was obtalned previously by subtracting the measured resiativity for an ordered vanadium carbide $\left(V_{6} C_{5}\right)$ from that for $a$ disordered sample $\left(V_{0,84}\right)$. We have now shown that the functionsl dependence of the residual resistivity on temperature can be fitted exactly by a nodel based on the temperature dependence of the Fermi energy for a colld with slightly overlapping energy bands. This situation obtalns for TiC and VC, where the Fermi energy falls near the minimum. between a filled bonding band and an unfilled antibonding band derived frok metal 3d and carbon 2p states. This result and others characterizing electron scattering by defects in the carbides will be presented at an Invitational conferance on solid compounds of the transition elements in Uppala, Sweden, in June, 1976. 
Another clartfying interpretation of the peculiar behavior of the carbides was provided by work durfing FY 76: the fncrease in the electronic contribution to the thermal conductivity of T1C at high temperatures reported in the literature was analyzed in terms of bipolar diffusion of electron-hole palrs diffusing down the temperature gradient and recombining with release of energy--i.e., transport of heat. This process is well known in semiconductors, and following the suggestion of Gallo, et al., for semi-netals, we have applfed the calculation to the carbides. Since the experimental data avatlable show considerable dispersion, it is difficult to demonstrate that any specific mechanisu is active in this high-temperature transport process, but the results obtained here indleate that the bipolar diffuston interpretation could be and probably is correct.

Last year, we looked ahead to trytng to apply the model of electronic damping of dislocation kink motion in covalent solids developed here (Ph.D. thesls, A. P. Gerk, 1973) to our recent weasurements of dislocation velocities in S1 (Ph.D. thests, S. Kulkarni, 1975). This analysis was completed during FY 76 and showed, as hoped, that the motion of individual dislocations over macroscoptc distances in pure and doped $S 1$ can also be interpreted by the electrontc damping theory. As the kink moves at the high temperatureg required, the tocal equilibriun of electrons and holes in the conduction and valence bands is disturbed; relaxation to the equilibrtum state is facilitated by internal Auger recoubination processes. The probability for these processes increases as the concentration of electrons or holes in the bands. Thus a doped sample will come back to equilibrium faster than an undoped one as a kink moves in the solld, so the effective force opposing kfnk motton will diminish. One should see a reduction in the activation energy for motion of dislocations. The experfmental results bear out this prediction: the activation energles for dislocation motion in both $n$ and $p$ type $S i$ are reduced by $a$ factor of one thalf the band gap over that found for pure $S 1$, in accordance with the prediction of the model. Thus two experiments in this group--1nternal friction in $S i$ and dislocation velocity measurements--support the idea that electronte drag effects limft dislocation motion in covalent sollds at high temperatures. If this result stands, it will be an Important contrlbution to our understanding of how hard, brittle materials soften at high temperatures. Such understandjng is important in the selection and design of materialg for use in any high-temperature system where retention of high-temperature strength is Lmportant (e.g., fusion reactor, advanced nuclear reactors, MHD generator, etc.)

An Important result was obtained in FY 76 on another hard, brittle materlal-bone. Our prevtous work on the electrical properties of this material demonstrated that the $81 \mathrm{gnals}$ produced in bending besms cut from long bonss could not be salyzed in terms of the usual third-rank tensor theory of plezolectricity but instead required a fourth-rank tensor formalism. Other bone research groups have ralsed questions about the ultimate biological 1oportance of this finding since the measurements were made 
on dried specimens. During the last several months we have repeated the messurements of bendfng "pfezoslectricity" on molet bone specimens, fncluding sone that were freshly excleed. In all cases, the qualitative features that demonstrated the need for a fourth-rank tensor theory for dried bone were duplicated with the molst apecimens. We conclude that the findings may indeed be lmportant for blology. With colleagues from Veterminary Mediclne we have demonstrated the necesstty for electrical signals. In the normal functioning of growing bone by inducing osteoporosis In 1mobtlized rabbit bone and preventing it in other 1moblitzed rabbits by supplying the missing electrical signalg artificlally through implanted electrodes.

During FY 76 the princ1pal Invest1gator returned to the Laboratory from one-year leave of absence as an Energy Research Coordinator for the National Sctence Poundation, Washington, D. C.

Results Expected, FY 77: Duxing FY 77 we expect subatantial progrese on a new project, the role of lattice defects in catalysis. An experinental program is being inttiated in FY 76 for a study of the influence of deviations fron stolchfometry on the electrocatalytic activity of tumgsten carbide in the oxidation of hydrogen in a fuel cell. By the end of FY 77 this project should have added to the experfinental data already in the literature which 1ndicate increasing activity with increasing deviation from stolchlometry (Increasing concentration of carbon vacanciea). In addition, the profect should produce better characterization of the nature and magnitude of this deviation. Comparative results on WC and TIC should Eurther define not only the dependence of catalytic activity on carbon vacancy concentration, 1-x, but also on the syometry of bonding orbitals in the nelghborhood of the point defect, since T1C 18 cublc and wC 1 s hexagonal. In addition, sone conclustong about the role of an oxygen aton substituted. for carbon in the vacancy should be avallable. He expect experimental results on powders of the carbides and on single crystals, in two quite different experimental geometries. In both cases, the results will be used to test predictions made from the concurrent theoretfcal effort, which uses cluster methods to calculate the binding energy of hydrogen to specific surfaces, with and without defects, including vacancles and substitutional tmpurities. The principal result antictpated from this resesrch profect during FY 77 will be strong evidence elther supporting or contradjeting our present hypothesis that the active site for catalysis on solid surfacee ts a point defect.

By the end of FY 77 an investigation of the reported relation between zeta potential, applied electric fleld and surface hardness of ceramics should have been brought to the point of confirming or contradicting the clatms 1n the literature. If the claims are borne out, the application of different models to interpret the results will also be well along by the end of this pertod. 
The local orbftals calculations of total energy of all the carbides should be completed by the end of FY 77 and from these results the planned calculation of elastic constants should also be completed. Detalled comparison with experimental values where avallable should by this time allow one to assess the utility and accuracy of the theoretical methods in predicting certain mechanical properties of the solid from detasled knowledge of tts electron1c structure. The calculation of electron densities in real space ahould also be conpleted during this pertod.

In addition to the results expected in FY 77 on synthetic caranic materisls, a conclusion should be reached concerning the origin of electrical effects in the blological ceramic, bone. Experialents planned for the coming year will ether support or refute the Japanese proposal that the bending "plezoelectricity" observed in bone results from displacentent of excess space charge. Electrical properties of selected. polyners subjected to electron 1rradiation and charge 1njection by high dc flelds will be compared agalnst the predictions of the Japanese theory.

Results Expected, FY 78: Additional evidence on the suspected relation" between point defects and catalys is will be accumulated during this pertod if the relation is aubstantlated by the rasults of FY 77 . This theme is of such general signiftcance to the bastc sctence underlying as important energy-saving mechanisn that the work will be cont-1nued for several years and expanded, providing that it is on the right track. The experiuental studies planned for the carbides in the area of catalysis will be extended during this period to oxides. The thooretical results coning from A. B. Kunz's group suggest that the oxygen atom is an fmportant component of gome catalytic processeg. Since metal surfaceg are generally covered with an oxide fllm in practical situations, ever metal catalysts may operate through the mediation of an oxide or at least a cluater of oxygen atoms: This possibility will have been explored for the spectfic case of oxygen substituting for carbon in the nonstoichiometric carbides in FY 77; in FY 78 the study will be extended.

The data accumulaced on surface environment and hardness of semiconductors, Insulators and semimetals during FY 77 will be analyzed durfing FY 78 and spectfic models explored. The tunneling hypothests advanced by Gilman, for example, should elther be supported or rejected by the analysis. The models of electron interactions with moving dislocation kinks developed by Gerk and furthered by Kulkarnd in this group way have a bearing on the surface hardness problen and will be exantned for this purpose.

The cluster calculations begun In FY 76, and applied to defects at the surface of carbides 1n relation to catalysis in FY 77 will be carriad further in FY 78 in collaboration Wth Kunz's group; The local electronfc environment. near a vacancy in the bulk will be treated in deta11 to calculate vacancy interaction energies which lead to the ordering of some 
of the nonstolchiometric carbides. These ordered conpounds, $\mathrm{V}_{6} \mathrm{C}_{5}$ and $\mathrm{V}_{9} \mathrm{C}_{7}$. for example, have already been studied to show the dramatic reduction in restdual electrical resistivity acconpanying the orderiag, but no understanding presently exists of thy the ordered phases represent a lowering of the total free energy. To explott the improvement in properties in the ordered phases for applications to energy technologies where better refractory materials of high electrical conductivity are needed, we need also to understand the reasons for the orderting so that ordered phases can be cugtow-designed.

Other 1mportant results fron the theory effort, continued in collaboration with A. B. Kumz, should be forthcoming as the general scheme of predicting mechanical properties from the electronlc atructure is developed. The cemperature-dependence of the hardness, discussed above as a limiting practical characteristic of the refractory carb1des, will be exanined during FY 78 to gee how much of the effect $\mathrm{is}_{\mathrm{s}}$ due to spatial delocalization of bonding orbitals resulting from thermal fluctuations. This line of approach would be separable from studies of dislocation glide and clitab, and the diffusion of carbon and/or metal as mechanisms responstble for plastic deformation. Sone information is avallable on theae processes, and will be reviewed and extended as necessary, such that by the end of FY 78, a reasonably conplete picture of the temperature-dependence of the hardness of the carbides can be given. With this detalled knowledge, strategles can be devised to reduce the amount of plestic deformation in theie ceramic materials at high temperatures through alloying, doping, etc.

An effort that would complement the study of high tamperature ooftening fn the carbides is a study of the roon-tenperature brittleneas. This characterfetic fs also very liolting to the utilization of these naterials. W1th the knowledge belng developed frow the theory progran on electron distribution in the meterials, and on the location and strengthe of the vartous covalent bonds, it should be possible to recominend doping and alloying agents that would reduce the bond energy and hence also reduce the Pelerls stress controlling dislocation kink fornation. These two complementary otudies w11l be conducted in BY 78 if poss lble and wight lead to suggestiong for designing improved modifications of critically-needed gtructural ceramics for future evergy technologies.

Relationsh1p to other Federally Funded Projects: The oingle erystals of the transition-metal carbides that have been obtalnad through the years by purchase or gift are shazed with other 1nveatigators in the Illinols MRL. For example, Professor Klefn's group has studled Raman scattering in crystals of titanium carbide and has found, ss expected, that the defect structure of these nonstolchlometrlc solida allows Raman ocatterlng events to occur even though the crystal structure is cuble. These results are being compared with aintlar activity at Oak RIdge. The measurements are anong the first on metallic systens and should in tine help in a nore detalled characterization of the electronlc atructure in the nefghborhood of the carbon vacancy--the defect in this class of materiale that controls all the transport properties. 
Discusstons with Professor F. Brown In the I11fnots MRL have lad to a plan For study of the $\mathrm{X}$-ray absorption edge as a function of carbon/netal ratio In the transition-metal carbides. Again, the cryatals on hand will be used. Although similar measurements have been conducted at Wright Field and at Uppsala, the combination of local expertise in thege materials and in the $x$-ray measurements should produce definttive results that can be 1ncorporated In a nore compehensive view of the bebavior of the carbides.

The recent extengion of the present progran of research to a study of catalysis in tungsten carbide has made contact with the theoretical studies of catalya1s under Professor Kunz of the I111nols MRL. Prelininary resultg from his theoretical wethods have been obtalned, at our suggestion, on the posatble reasons for the gxoss difference in catalytic activity for WC compared with TIC.

Another research effort in the Illinots MRL on trangition metal carbides-apactfically the cenented carbides uged for machlning purposes--has recently been Inltiated through the Department of Ceramic Enginenring with NSF funding. This effort is obviously closely related to that supported under the ERDA block grant through this project but is diatingwiahable through the speciflc. nature of the purpose for which the NSF grant was nade: to test the proposition that the primary cause of early fallure of cemented carbide cutting tools is the raptd softening of carbides at high temperatures. Preliminary restults on this subject were obtained under ERDA support in FY 75 (Baldoni).

Collaborative work with Oak Ridge on grapkite for orthoped1c implants continues but at a reduced level, as the nearby facilities at the Univerafty of Tennesser are ut1lized more extenstvely by Oak RIdge.

A natural interaction with the investigators in the Illinolg MRL workfng on Interstitials in transition metals will be developed in the coming year. The natertals studied, the trangltion-metal carbldes, are sometimes called "Interetitial compounds" and represent a liniting case of the introduction of interstitial carbon into a matrix of a transition metal.

The recent activity of this group (two Ph.D. theses) in the area of dislocation motion in covalent solids, Including one gtudy of internal friction, provides a potential lfnk with other strong efforts on dislacation behavior in solids pursued in the Illinols HRL by several other Investigators, Including Profesgors Granato, Koehler and Birnbaum. Th1s patential will be explored in the coming year.

For geveral years, this group has carriad on a project to anclyze and interpret the plezoelectric behavior of natural bone. Additional oupport for this project has now been obtained from another federal agancy, NIH, which is carrying one graduate student in physics as a Trainee in the Bloenglueering Progran Tralneeghip Grant on the Urbana campus. 


\section{Publications: (Calendar Year 1975)}

Lance Breger, Marola Johnson, and Wendell Willians

Ptezoelectric Response of Inorgantc and Blological Materials Subjected to Inhomogeneous Stress

J. App. Phys, (aubmitted to)

Dwight $R$. Jemitson and A, Barry Kunz

Degree of Ionteity In Crystalline $\mathrm{NaF}, \mathrm{NaCl}, \mathrm{SrF}_{2}$ and $\mathrm{SrCl}_{2}$ as Found by Local Orbitals Hartree-Fock

Phys. Rev. (aubmitted to)

Also supported by NSF-DMR 72-03026 and ARL F33615-72-C-1506

S. B, Kulkarn1 and W, S, Williang

D1slocation Velocities and Electronic Doping 1n Silicon

J. Appl. Fhys. (submitted to)

M.S. Theees: (Calendar Year 1975)

None

Ph.D. Thesese: (Calender Year 1975)

Joseph Gary Baldont II (W. S. H1lliams, Adviser)

High Temperature Deformation Behavior of Cemented Carbide Cutting Tools January 1975

Subhash B. Kulkarnt (W. S. Williams, Adviser)

Velocities of Screw and $60^{\circ}$-Dislocations in Intriasic and Extringle silicon October 1975 
ED-02-01-02-0 Mechanical Properties

Interstitial Solld Solutions

Priacipal Investigator: Carl J. Altstetter, Sc,D.

Professor of Physical ifetallurgy

Supporting Agency: U. S. Energy Research and Developnent Aduinistration

Sen1or Staff: Carl J. Altstetter, Professor

Junior Staff: Gary L, Steckel, Regearch Assistant

Peter F. Tortorelli, Research Assistant

Object: The objective of this program ts to discover and underatand the behavior of group $V$ rafractory metals, vanadium, nioblum and tantelum, and to assess sone aspects of their sultabllity for energy-related applications. of particular concern in poteptial nuclear epplications are the reactivity and degradation of these netals by oxygen in their operating environments, one part of the progran deals with the solubjlity of oxygen and the compositlonal dependence of the enthalpy and entropy changes when oxygen dissolves in the netals. These quantitles are used to test statistical wechasical interstitial solution models and to infer atomic inceraction parameters. It is expected that this will sigulficently improve our understanding of the energetics of interstitlal solid solutions of bcc netals. The principal technique ts the measurament of the equilibrium potential developed in solid state galvanic celis having different oxygen alloys as electrodes and an oxygen ion conducting electrolyte. Measurements are made in the range $650^{\circ} \mathrm{C}$ to $1250^{\circ} \mathrm{C}--j$ ust the temperature range these netals' would experience in nuclear stxuctural applications.

The other part of the program is a study of the effects of energetic ion boubardment on the sputtering of metal atoms and the resulting surface topography. Th1s problem is relevant to the use of naterlals in fusion reactors where structural integrity and high vacuun compatibility of the naterial is important. Of even greatar importance ts contamination of the plasma with metal and adsorbed and disoolved atoms, leading to greater plasma energy losses and Inablitty to achieve critlcal confinement at oufficlently high teuperatures. Nloblum and vanadiun and their alloys with oxygen are exposed to $\mathrm{H}^{+}$, $\mathrm{He}^{+}$and $\mathrm{A}^{+}$Ion bens at up to $30 \mathrm{keV}$ energy. Our scientiflc objective in this. part is to test sputtering theories and determine the processes by wh1ch topographical features forn and evolve. Sputtering yleld is measured by optical and weight loss measurements. Scanning electron nicroscopy, interferonetry and nutcroproftlonetry are used to assesa the topographical changes. Auger electron and $x$-ray spectronetry are used to determine surface compositional changes and electron channellag is wed to deternine structural damage and crystallographic information.

Regults. FY 76:

Most Stgmiftcant Accom lishments: Determination of the solubility and the chendca potent $19 \overline{1}$ of oxygen in vanadium. Identification, for the first tine, of a cyclic atom removal. process during sputtering. 
Publighed work by $\mathcal{N}$. Carlson of Ames Laboratory and $D$. Smith of Argonne Laboratory were in sharp dieagreement on the solubllity of oxygen in vanadiun, differing by about a factor of two. Using our enf technique we were able to verify the results of one of the groups. We are presently exploring with the ather group the reasons for our disagreement. Besides the bastc scientiflc interest, our results on this eystem are ioportant to one of the techniques for wontoring the oxygen content of the sodium coolant 1n the UMFBR progran. We were able to formulate analytical expressions which describe the activity of oxygen in vanadium for all compositions in the ingle phase region in the temperature range from $650^{\circ} \mathrm{C}$ to $1250^{\circ} \mathrm{C}$. Below 3.0 at.7 o the solutions obey Henry's 1ew, but deviate significantly above that couposition. A correlation ueing Darken's alpha parameter proved succesgful at higher conpositions.

Production of $V-k b-0$ alloys has begun for the next phase of this work.

In FY 76 our Ion beam appsratus became operational. Dur early experiments using $15 \mathrm{keV}$ azgon 1 ons on $\mathrm{Nb}$ and $\mathrm{Nb}-0$ alloys underscored the need to consider the orientation dependence of sputtering yield in polycrystalline specimens, particularly when dealing with uaterials having a cryotallographic texture. Differential sputtering of grains can give rise to a stepped structure and ultimately to cyclic rather than steady state gurface irregularity. We suggest a ledge mechanlen to account for the cyclic production and destruction of surface 1rregularities. There is evidence ouggesting that these surface Irregulartties--cones--are intrinsic features rather than due to 1mpurtty solutes or phases. The signiflcance of these results is that the rate at which materlal is lost from the first wall of a fuston reactor may be greater than that predicted by measurements on aingle crystals. of further significance ia the implication that techniques which depent on sputtering for surface chemlcal analysis (Auger spectroscopic proftling, secondary Ion mass spectroscopy) noy have less depth resolution than generally assuned, due to differentlal gputcering and cone fornation. Apparatus for in situ sputtering yleld measurement is under construction. Sample holders for elevated temperature and for sfmultaneous stressing, heating and irradiating are being deafgned.

Results Expected, FY 77: In the regearch with oxygen in solution we hope to complete the work with V-Nb-0 alloys. This particular ternary syaten to chosen because we alraady have determined the complete thernodynanic description of both binary syatens. The $\mathrm{Nb}-\mathrm{rlah}$ and $\mathrm{V}-\mathrm{rlch}$ alloys allow us the opportuntty of measuring Bolute-oxygen interactions in which the solute bas a higher or a lower affinity for oxygen, respectively. The results will be used in several of the statistical formulations for intergtitlal golld solutions to test their validity. and to predict ternary behavior from a knowledge of binary syoten behavior. If posetble, measurements on the $\mathrm{V}-\mathrm{Ko}-\mathrm{O}$ or $\mathrm{Nb}-\mathrm{Ho}-\mathrm{O}$ aystems may be uged to predict Mo-O binary syotem behavior.

If a modeet increage in manpower is available, 1t w111 perntt an inmediate expansion 1nto the use of thin layer galvanic cello in which the electrodes and electrolyte are deposited from the vapor phase. This would give a 
tremendous boost to the application of the enf technique to much lower temperatureg or to faster responge at high tenperatures. Such thin film devices could prove useful for on-line control of combustion processes for more effictent utilization of fuels. They nay also open up the field of cathodic protection of refractory metals againgt ntidly oxidizing environments. Another possibility would be batterieg or fuel cells for elevated temperature operation.

In the sputtering work wo expect to have results on creep enhancement under 1on 1rradiation conditions. We also will be making yield meastements on other taterials besides No, $V$ and their alloys. FY 77 should gee results using targets of low $\mathrm{Z}$ materials such as aluminum, sintered aluainum powder (SAP) and atuminum/graph1te or aluminum/SIC composites. Experiments w11 also be done using tighter 1ons, $H^{+}$and Het. The effort in this part of the program will be to minlmize target erosion and plasma contant'nation by mantpulating the metailurgical etructure of the material. Experfments on neutron Irradiated materlals will cóntinue.

Results Expected, FY 78: The oxygen work could branch into another or into two related projects, depending on the results in Fy 77 and the level of support. One of the projects would be a continuation of the fundanental work on alloys contalning oxygen and the developwent of soltd solution models. The other branch would concentrate on thin film galvanic cells, described briefly under FY 77 expected reauts. The former option would probably be followed if no increese in support level is forthconing. In the sputtering work we will continue using different target materials, trying to strengthen our knowledge of sputtering mechanlams and demonstrate generality of our observations. Surface coatinge and compositional wdification of aurtaces will be investigated. Hore effort will be expended in transmission electron dicroscopy to assess the near-surface damage due to ion bombardinent. Collsboration will be sought for $14 \mathrm{MeV}$ neutron-damaged specimens and/or high energy heavy metal ion irradiation prior or aubsequent to ion damage. It is hoped that Rutherford backgcattering capabilftiea will be available on campus as an analytical tool In this time perlod. Such medaurements would greatly enhance our ability to characterize fozting and compositional alterations.

Relationship to Other Federally Funded Projects: Close cooperation is maintalned with the MRL, project of $\bar{R}$. Yoske, with stom we share equipment. for the annealing and oxygen doping of refractory metal speciuens. L1kewise, wiţ G. 'Wert's MRL project we share use of the zone melting apparatus for the production of binary alloys of refractary metals. Thex Is also a elose relationship with H. Birnbaum's MRL group which has supplied us with ultra pure test material. With all these groups there is wore than just equipment sharing, because we freely exchange information on alloying behavior, heat treatuent and handling techniques peculiax to the refractory metals with which we all work. The coordination is such that between us we study all the interstitial solutes $-\mathrm{C}, \mathrm{O}, \mathrm{N}$ and $\mathrm{H}-\mathrm{In}$ niobium and vanadium, but do not duplicate any of our efforts. The potential for 
duplication of effort is greater with groups working on oxygen in vanadium at Ames Laboratory and Argonne Nationa1 Laboratory. Unwerranted overlap has been avolded by maintatning frequent cosmunfestion with workers at these laboratories. In our sputtering work wo are beginning toint experitents with M. Wechsler of Ames Laboratory to determine yielda in neutron dambged vanadium oxygen alloys. This allows us to cone one step cloger to fuston reactor conditions.

Publications: (Celendar Year 1975)

None

M.S. Theses: (Calendar Year 1975)

None

Ph.D. Theses: (Calendar Year 1975)

D. Shah (C. J. ALtstetter, Adviser)

Deformation of Vandium Contalning Diopersed $v_{16} \mathrm{~N}$ Particles October 1975 
Hydrogen Behavior in BCC Metale

Principal Investigator: Howard K. Birnbaum, Ph.D.

Profestor of Phyalcal Metallurgy

Supporting Agency: U. S. Energy Reaearch and Developtrent Adntalstration

Sentor Staff: Howard K. Blrnbatm, Professor

Chee Gregoxy Chen, Research Assoctate

MuneyukI Amano, Visiting Regesrch Assoclate Profeasor

Juntor Staff: Joseph J. Au, Research Asg1stent

Gerald R. Matusiewicz, Regearch Asalstant

Robert Sherman, Graduete Student

PhIl1p E. Zapp, Research Aosistant

Object: The primary focus of this work is on the behmilot of light Interstitial alements in metals. In the past few years and during the next contract period, emphasis has been and will be on the refractory metals $\mathrm{Nb}, \mathrm{Ta}$, and $\mathrm{V}$, on the ferrous alloy syetem, and on the Interstitfals bydrogen, deuterium and helfum. Four aspects of the behavior of these system are being 1nvestlgated; (s) the diffugion of the interstitfal solutes, (b) the local vibratlonal modes of the interstitials (with M. Kletn), (c) the precipitation of hydrides (with $H . L$. Fraser), and (d) the behavior of $H(D)$ and $H_{2} S$ on the surfaces of the refractory netals (with $M$. Kletn).

The behavior of light 1nterstitial element in bce metals is of major scientific Interest es they represent systems in which the diffuston occurs by a quantion mechanical tunneling mechantam. This behevior monifeats itself by a marked deviation from the usual Arrhenlue dependence of the interstitial junp frequency at low temperatures, by anomalously large 1sotope effects, and by extremely high diffusivictes. These effects are being atudied in the $\mathrm{Fe}-\mathrm{H}(\mathrm{D})$ system ustng wagnetic relaxation wethods and $1 \mathrm{n}$ the $\mathrm{Bb}-\mathrm{H}(\mathrm{D})$ system uoting the techniqued of anelastic relaxation, onelastic ptezoresistance, and the Gorsky effect. Since tunneling of the light 1nterstitials is closely coupled to the lattice phonons, the local vibrational modes of H(D) are being studied in $\mathrm{Kb}, \mathrm{Ta}$ and $\mathrm{V}$ using the nethods of Ranan spectroscopy.

Very little is known about the behavior of He in wetals and easentially nothing 15 known about 1ts behavior when present as an uatrapped intergtitial solute. Th1s problem is being fnvestlgated using the above techniques in the $\mathrm{Nb}-\mathrm{He}$ systan. Since very appreciable concentratfons of He are generated in components of the fission reactors and even greater quantities will form in the fuston reactor, this gtudy has particular relevance to the problens of hellum embrittlement and hellum bubble formation. 
In addicion to the scientific intereat in the behavior of the light interstitial elements, the above gystens are of great technologlcal signfficance in connection with matertals behavior in energy production and transport. The problen of hydrogen Bubrittlement of technological alloys is present in both fission and fuston reactor systems as well as In coal gasification systens (where it 1g particularly aggravated by the presence of $\mathrm{H}_{2} \mathrm{~S}$ ). In energy transport systens baged on pipeline transmisston of gases containing $\mathrm{H}_{2}$ or $\mathrm{H}_{2} \mathrm{~S}$ the enbrittlement by hydrogen is an 1ncreasingly signtficant problem. Additionally, the stress corrosion of tany alloy systens appears to be intinately related to hydrogen entititlement by gases releaged at the crack tip. As our previous gtudies have shown, the embrittlement of alloys by Internal hydrogen 19 controlled by the kinetics of diffuston to a crack tip; hence we are studying the effects of $H$ trapping centers such $a s, 0$ in $\mathrm{Nb}$ and $C, N$, and $I I$ in Fe on the diffusivity of $\mathrm{H}$. Hydrogen embittlement from a gaseous envirorment is controlled in part by the entry of hydrogen fron the gas phase and we are therefore studying the behavior of $\mathrm{H}$ and $\mathrm{H}_{2} \mathrm{~S}$ on the surface of metals ualing the Raman technique. Embrittlement of the Group Vb elements 1s related to the fornation and cracking of hydrides. The hydride prectpitation mechanisms are betng studied in these sygtems using transmission electron nicroscopy as a primary tool. In addition to the problem of hydrogen embittlenent, the hydride properties are of interest in relation to energy storage and transport. Energy storage in the form of hydrides is of particular interegt in connection with "peak shaving" of power planta. Hydrides are also of increasing Interest in connection with systemg for refrigeration and mobile power generation.

The prtmary tool for the study of hydrogen mob1lity is Nb has been anelastic wethods in the frequency range of $0.01 \mathrm{~Hz}$ to $300 \mathrm{HHz}$ and in the temperature range $4 \mathrm{~K}$ to $300 \mathrm{~K}$. The tunneling wotion of $\mathrm{H} \mathrm{in}$ the $\mathrm{H}-\mathrm{H}$ and $O-H$ pairs is befing studied. In th1s Low tepperature range, single $H$ solutes are present at concentrations below the sensitivity of the acoustic methods. The mobility of single $H$ interatitials and the effects of 0 on this nobility is being exanined using the Gorsky wethod which allows long range diffusion to be studfed. The Gorsky technique is also being used at high temperatures to obtain raliable $H$ and $D$ diffusivities as these are of particulat interest in the fusion reactor progran. The anelastie methods also provide a means of otudying the effects of trapping aites on hydride precipitation and information of this type is being gathered.

Application of the anelagtic methods at low temperatures is somewhat limited by the low $H$ and He concentrations thich can be kept in solution. The anelastic plezoreolstance technique $1 s$ being developed to alleviate th1s constraint. In this method an acoustlc wave is used to caure stress induced reorientation of interstitial solutes and ac resistance methods are used to study anisotropy of the electron scattering fron thee laterotitials. This method is being applied to atudy the behavior of $\mathrm{A}$ in $\mathrm{Nb}$ at very low temperatures and of $\mathrm{He}$ interstitials in $\mathrm{Nb}$. 
The behavior of He in No is being examined in the temperature range of $4 \mathrm{~K}$ to $300 \mathrm{~K}$. The He $1 \mathrm{~s}$ being introduced in the interstitial form by ${ }^{3} \mathrm{H}$ decey to ${ }^{3}$ he at. $4 \mathrm{~K}$ and tto behevior is being monitored at $4 \mathrm{~K}$ and during isochronal anneals with resistivity pethods. A specific relaxation caused by stress-1nduced reorlentation of the fie is being sought using the plezoresistance method.

In the Fe-H system studies of $H$ behavior require greater sensitivity. than can be provided by the anelastic techniques due to the low $\mathrm{H}$ solubility. We will continue to use the magnetic relaxation techniques which we have developed and will apply then to a study of $\mathrm{H}$ trapping at Interstitial and substitutional solutes. These effects are intinately related to the problem of hydrogen embittlement of steela.

The Raman studies of $\mathrm{H}$ in $\mathrm{Nb}, \mathrm{Ta}$ and $\mathrm{V}$ as well as on the surface of these elements will be continued and the studies of $\mathrm{H}_{2} \mathrm{~S}$ on the aurface will be started. The problems of obtaining and malntaining a clean surface appear to be solved by carrying out the entire experinent in UHy and by cleaning the surface by electron beam heating. Our preliminary measurenents indicate that the sensitivity is sufficient to examine both H(D) In solid solution as well as to see adsorbed spectes at the surface. The deta is expected to yleld informstion about the vibrational mades of $H(D)$ In the interior and at the surface, the high temperature diffugivity of H(D), and density fluctuations of $\mathrm{B}$ at the spinodsl critical point. of particular interest will be atudies of the effect of adsorbed spectes such as $\mathrm{H}_{2} \mathrm{~S}$ on the entry of $\mathrm{H}$ from the gas phase. This information 19 of grest significance in understanding the embrittlement of materials by environtents conţafning $\mathrm{H}_{2} \mathrm{~S}$.

Results, FY 76:

Most Significant Accomplishments: The quantur tunneliag trodel for IIght Interstitial solute elements in bcc crystals, which was proposed by Fiynn and Stoneham, vas shown to be correct for the motion of $\mathrm{H}$ in the of conplex in Nb. This is the first direct experimentel confirmation of quantum tunneling of $\mathrm{H}$. Measurements of the $\mathrm{H}$ jump frequency from sbout $300 \mathrm{~K}$ to $20 \mathrm{k}$ ( $300 \mathrm{MHz}$ to $0.01 \mathrm{~Hz}$ ) were shown to fit the Flyun-stoneham theory extremely well.

A theoretical node1 of $H(D)$ behavior in bcc metals which is based on a delocalized H(D) interstitial has been developed in conjunction with C. P. Flynn of the MRL. Th1s theory can account for a wide range of hitherto dispsrate and seemingly conflicting experimentel resulta; the low tenperature jump frequency and heat capacity messurements, the anonalous neutron diffraction Debye Waaler factorg, the diffuse $X$-ray measurenents of distortion around the $H(D)$ solutes, and the lack of anelastic Snoeck relaxationa due to $H(D)$. 
Ocher Results: Analysis of the magnetic relaxacion data for the Pe-H(D) systent has shown that $H(D)$ occupies three interstitial sites in the Fe lattice which are the octahedral, tetrahedral and triangular altes. These correspond to specific relaxation paraneters which have been measured. It has also been show that $H(D)$ is very strongly trapped by $c$ and $N$ interstitial solutes with binding enthalpies of the order of $0.5 \mathrm{eV}$.

The crystallography of the on defect in Nb has been established uaing anelastic techniques. It was shown that three types of oH clusters exist, a $\langle 100\rangle$ nescest nelghbor, $\langle 110\rangle$ second nearest neighbor, and <lli> third nearest nelghbor palrs. The binding and reorientation enthalpies of each type of oH cluster has been deternined.

The hydrogen lsotope effects in both th and Fe have been established and are much larger than expected on a classical wodel. These effects may be consistent with a tunneling model, but at the present time are not accounted for by existing theorles.

The Raman studies have demonstrated a surprisingly large sensitivity to $t$ in the lattice and to $H$ containing wolecules adsorbed at the surface of $\mathrm{Nb}$. These results suggest that the Raman technique will be extrenely powerful in studying the vibrational and local phonon modes at surfaces and at H(D) solutes.

Results Expected, FY77: The program of studying the basic diffusion mechantsns of the Iight interstitial solutes in bcc metals will be continued. The anelastic piezoresistance method will be developed as a technique for studying the junp frequencles of interstitial solutes and clusters at extremely low concentrations. This technique will be applied to the H(D) behavior in $\mathrm{Nb}$ at very low temperatures in an attempt to observe the relaxations assoclated with single $H$ solutes. Two types of relaxations will be exanined (a) "diffuglonal" †umps of $H(D)$ centered around nearest neighbor octahedral sites and (b) relaxations wich result frov atressInduced change in the wave function of the delocalized $\mathrm{k}(\mathrm{D})$ solute. A parallel serfes of experinents will be carried out on the of relaxations to extend the temperature range in which these are observed down to $4 \mathrm{k}$ as a further test of the tunneling model for $H(D)$ diffusion. It w1ll be particularly interesting to exanine the lsotope effects at these very low temperatures.

The high temperature Gorsky effect messurements of $H(D)$ diffusion in th should be compleced during this contract period. These measurements will provide rellable high temperature dats and should elucldate the effects of trepping on high temperature diffusion. The Flyna-Stoneham tunneling rodel of diffusion suggests that a negative curvature in the Arrhenius plot of the diffusivity should be observed at about $500^{\circ} \mathrm{C}$. The experimental data should produce evidence for this effect if 1 t occurs and w\$11 provide further test of the tunneling model. 
Use of Rasen spectroscopy to study $H(D)$ behavior in Nb, Ta and $V$ wll be continued, The main thrust of these measurenents will be directed toward the behavior of 1nterstitial H(D). As the expertinents proceed, however, we will also be exaulnitg the vibrational modes which characterize adsorbed molecular species on the clean tetal surfaces. Of particular interest will be the behavior of $\mathrm{H}_{2} \mathrm{~S}$ because of its stgnificance in hydrogen embrittlenent processes.

Helium diffugion studies in Nb will concentrate on estabilisting the behavior of interstitial He introduced by tritium decay. The primary measuring techniques will be resistivity measurenents to establish the annealing behavfor during 1sochronal anneals frow $4 \mathrm{X}$ and anelastic plezoreststance measurements to establish the relaxation behavior of the varioug forng of He. Particular attention will be focused on the effecto of trapping sites on the diffusion.

The magnetfc relsxation studies of $H$ in Fe will be completed during this next contract per1ad. The expertmental work will determine the effects of stbstitutional solutes on the $H(D)$ diffusion. These rasults w11l be of spectfic interest in tuderstanding hydrogen enbrittlenent of ateels.'

Results Expected, FY78: It is anticlpated that the program will evolve in a natural way from the results obtained in FY 77. The magnetic Felaxation expertments on the $\mathrm{Fe}-\mathrm{H}(D)$ system described above should be completed and at present it is not anticlpated that this 11ne of research will be continued. It is also anticlpated that the characterlation of the oH defect in $\mathrm{Nb}$ will be completed. The focus of the anelastic and anelastic plezoreststance experimente will be on determinting the behavior of single $\$$ interstitials in $\mathrm{Nb}$. The high temperature Gorsky effect measurements will be exterded to other metal-hydrogen systeris.

If the Initial experiments on helium dffiuston are successtul, this phase of the work will be Increasiagly emphasized. Attention will be focused on the diffusion of interatitial He and its interactions with spectfic trapping sites. The transition from interstitial the to he gas bubbles w11 be studied using both resistivity and anelastic plezoresistance nethods.

The Raman atudies will continue to be applied to characterization of the vibrational todes of $H(D)$ in solution and of surface adsorbed molecules $\left(\mathrm{H}_{2} \mathrm{~S}\right)$. The local lattice phonon spactre near the 1nterstitials will be probed using these techniques. In addition the data should yleld information about the high temperature difEusivity. Exanfoation of the optical scattering in the temperature-composition region near the misctbility gap should yield information about the decomposition of the solid solution. Clustering of the hydrogen solutes should be measurable with the ogtfcal tuethods and wil provide a powerful method for studying the spirodal decomposition of the solld solution. 
Relattonghlp to Other Federally Fumded Projects: This program is closely correlated with an ONR spongored program which is directed toward a study of hydrogen enbrittlement in bcc metals. The mechanisms of fracture are being studfed in the same systems in which the hydrogen nobtlity is being determined. As the studies of surface adsorption effects an hydrogen entry develop it is expected that these will also be paralleled by fracture studtea .

The Rapan studies of $H$ in wetals is a joint program with M. Klein of the MRL whose part of the program has been supported by ARPA. The interaction has brought together a strong metallurglcal group and a strong light scatterting group whtch are examining a aerieg of problems which would be difficult for elther group to study atone.

The hydride prectpitation is a foint effort with Hantsh Praser of the MRL whose work $1 \mathrm{~s}$ supported by ERDA.

The heliun interstitial measurements are being carried out at the Undversity of Illino1s but the spectmen doping wh th ${ }^{3} \mathrm{H}$ ta being performed at Battelle Northwest by Dr. A. B. Johnson of the Corrosion Research Division. The project will be a joint one with Dr. Johnson's group.

The continuation of our studies of $H$ fn Fe will be a jolnt effort with Professor M. Bermstein of the Carnegie-Mellon Unlversity who has been studying the effects of substitutional solutes on 1 embrittlement of steels.

Close coordination of the program is naintalned w1th the MIR measurements of hydrogen mobility in niobiu of Frofessor T. Rowland with ERDA oupport, with the theoretical studies of quantim mechanleal diffusion mechantsms of Professor C. P. Flynn with NSE support, with the ultrasonic investigation of hydrogen in metals of Professor A. Granato with ERDA support and the ERDA supported program of fracture of Professor N. Pugh.

\section{Publlcations: (Calendar Year 1975)}

H. K. Birnbaum and H. Wadley

Hydrogen Embrittlement of Molybdentm

Scr1pta Metallurgica 9, 1113-1116 (1975)

Also supported by the Jnited K1ngdom Atomlc Bnergy Establishment at Harwe11

R. F, Mettag and H. K. B1rnbaum

Isotope Effects on the fotion of 0-H Clusters in Nb

Acta Metall. $2 \underline{3}, 973-977$ (1975)

M. F. Bluem and H. K. Birnbaum

Determination of the Thermally Activated Deformation Paraneters in Nb and Nb-N Alloys

Proceedings Int'1. Conf. on the Strength of Metals, France, 1976 (to be published) 
M. L. Grossbeck, Peter W11lians, Charles A. Evans, Jr., and H. K. Birnbam Application of Ion Probe Analysis to Studies of Hydrogen Behavior in Solids qhys. Status Solldii A (in press)

Also supported by NSF

Peter Williams, Charles A. Evans, Jr., Martin L. Grossbeck, and Howard K. Bimbaum Ion Microprobe Analysis for Niobiem Hydride in Hydroget-Embrittled Nioblum Anal. Chem. (In press)

A1so supported by NSF Grants DMR-72-03026 and MP5-72-05745 and ONR N00014-67-A-0 O05-0020

M.S. Theses: (Calendar Year 1975)

None

Ph.D. Theses: (Calendar Year 1975)

None 
Applications of Electron Microscopy in Materiels Sclence

Principal Investigator: Hantsh L. Fraser, Fh.D.

Assistant Professor of Metallurgy

Supporting Agency: U. S. Energy Research and Developuent Adninistration

Sentor Staff: Hamish L. Fraser, Agglstant Professor

Junior Staff: Scott E. Hughes, Research Assistant (Term 9/20/75)

Nestor J. Zaluzec, Research Assistant

Object: The principal aim of the proposed research is to apply the techniques of electron microgcopy to studieg in materials sclence. As such the program is divided Into two sectlons. One part consists of an Investigation of the omega phase transfotmation in $2 \mathrm{r}$-Nb alloys using anatytical and high resolucion electron afcrogcopy. The second represents a change in exphasis in the current research program fron studies of elevated cemperature defornation of B-N1Al single cryotals to those Involving the decermination of mechanisms of environnentallyInduced fallures in structural matertals, and $1 \mathrm{~g}$ a part of a more comprehenstve study presently in progress at this Univeraity.

In the case of the studies of the omega phase transformation in 2r-ib alloys, the all of the current experiments is to use the most recent analytical techniques in electron microscopy to derive a more decalled understanding of th1s type of phase transition. Meny of these new techntques are not well developed and it has been necessary to perform a number of exper 1ments which have led ws to the point where we are now able to apply these techniques with some degree of conffdence. Speciflcally, Inaging of defects and micro-area diffraction using scanning transmission electron wicroscopy and quantitative microchemical analysis of thin foils by the use of energy dispersive analysis of X-rays have been studied. The results of these preliminary studies uill be degcribed in "Results, FY 76", but 1t 19 worth noting that simple application of the avallable techniques without careful analysis of the regults may lead to errors in characterization.

The study of the onega phase trangformation has reauled fron the interaction of the princtpal Investigator and Professor H. E. Cook of the Departmente of Mechanical and Metallurglcal Englneering. Cook is well known for his theoretical description of the onega phase trangformation, and $i t$ is one a1m of the current experfaents to check the predictions that result from his theories.

The omega phase transformation has been the subject of nuch study over the last decade. Ortginally, the transformation was charactertzed by the use of $X$-ray diffraction techniques. More recently, electron microscopy has been utflized to obtain not only diffraction data but also aome direct observations of the transformation products. The observations made to date Indicate that, on quenching from the bec solid solution phase field to roou temperature, the omega phane precipitates in the form of very small particles ( - $15 \mathrm{~A})$ vith a spacting of - $25 \mathrm{~A}$ between particles. 
Moreover, the 1mages of these particles are not stable with time but are repeatedly forming and disappearing. The suggestion has been made that one ga particles are continually transforming to the bcc phase and then reverting back to the hcp onega phase. It fs felt that more experimental work is needed to elarify this point. The proposed work on the onega phase transformation would 1nvolve a critical experimental review of the mfcrostructures pertaining to thermal and athermal transition products. The structures will be analyzed using bigh resolution and analytical electron microscopy.

The second part of the proposed program consists of atudies related to environmentally-induced fallures in structural materials and is thue part of the comprehengive study of such fallures currently in progress at Illinots. Professor H. K. BIrnbaum and his research group have performad experiments to determine the mechanisn of hydrogen embrittlement in Nb-H alloys. The results of their work indicate very strongly that the fracture of a hydride formed ahead of the crack tfp is responstble for the embrittlement. In view of th1a, a joint program was initiated with the afm of observing the morphalogy and determining trangformation wechanisms of the hydride in $\mathrm{Nb}-\mathrm{H}$ alloys using analytical electron microscopy.

Precipitation of hydrides in thin and thick folls from the solid solution is being studied. Further, the effects of varying the rethod of hydrogen charging are also belag determined.

In addition to these studies of hydride precipitation in Nb-H alloys, a comprehensive study of the embritelement of $\mathbf{z r}$ and $1 \mathrm{ta}$ alloys by iodine Is planned. Such embritclement has been observed in reactor enviromments, but has not been characterfized to any great extent. In view of 1 ts relevance to the other studies on environnentally-induced fallures in structural materials currently in progress, it is planned to perform a detalled study of this embrittlement phenomenon. One posstble nechentsm of embrittlement is the brittle fracture of as lodide at the crack tip, so that a detalled study of fracture faces using the electron microprobe and Auger spectrometer w111 be made. In addition, the possibility of forming lodides in these alloys will be studied using analytical electron wicroscopy to examtine thin folls which have been reacted with lodine vapor.

Results, FY 76:

Magt Significant Accompleshnents: During work almed at determining Increases in usable foll thickness when using scanning transmission elect ron olcroscopy, fofls of St containing stacking faults were 1rradiated with $200 \mathrm{keV}$ electrons. It has been show in this work that auch electrons are sufficiently energetic to displace S1 atoms fron the lattice, with the result that interstitial defects are nucleated at the stacking faults. Previous estimates of the threshold voltage for displacenents of SI atoms by electrons was algnfffcantly higher then this value; this difference is probably due to the presence of the stacking faults acting as nucleating sites for the lnterstitials produced by electron Irradiation. 
Dther Results: The main emphasid of our work during FY 76 has been to develop a number of technlques in analyctcal electron nicroscopy. Spectfically, tn the case of scanning transmission electron microscopy (STEM), it has been determined that, contrary to expectations quoted In the literature, for crystalline materlals no increase 1n ubab lo foll th1ckness 18 realized when using STEM. Thls led to the determination of the limitations to usable foil thlckness in conventional transmission electron ficroscopy (CTES), particularly light elements. It has been found that either finite angle inelastic scattering effects, or inelastic gcattering Involving loss of contrast limits usable foll thickness. Thus, while the effects of chromatic aberration are important, they are not 1imiting in the case of thick folls in CTEM. In the case of application of energy dispersive analysis of X-rays generated in thin folls, advances 1n data reduction have been ade. A background subtraction and profile fitting computer program has been developed from flrst principles, and this computer program is befog used to provide quantitative microchemical analysis in thin fo1ls. One assumption that must be made when applying quanticative analysis methods is the fact that the ratio of peak intensities of two elements be independent of fofl thickness. We have checked this using an honogeneous foll of NGAl, and observed a variation in this rat1o. Part of this vartation is attributed to differences in excftation and absorption of X-rays with atonfe number and fofl thickness; whereas in very thin parts of the foll, the spectrum 1 s dominated by X-ray fluorescence excited by Brensstrahlung produced at varlous points in the electron optical colum. The Bremsstrablung effect can be minintzed by usfing spectal colum liners, and the other effects can be predicted, and thus corrected for, by calculation.

Results Expected, FY 77: On the work concerning the otnega phase transformation 1n $\mathrm{Zr}-\mathrm{Nb}$ alloys, $1 \mathrm{t}$ is expected that the equllibriun structure w111 be deternined experimentally. This structure will be compared with that predicted by theory. Furthermore, thermal cycling between room tenperature and $77 \mathrm{~K}$ should result in the formation of ralatively large omege particles, and these will be atudied in the electron microscope. These structures wll be compared with that produced by slow furnace cooling,

In the case of hydr1des in $\mathrm{Nb}-\mathrm{H}$ alloys, the in situ cooling experimants wil be continued. There have been gome problems assoclated with the formatton of oxfde particles in our alloys; 1t may be posidble to Identify the oxides using electron energy losa measurenents and such a determination 111 be attempted. The experiments on bydride precipitation will be extended to cover the spinodal decotoposition occurring at the miscibility gap.

Experiments to characterize the Exacture of $\mathrm{Zr}$ and $\mathrm{Zr}$ alloys in an lodine environtient will be started. Auger spectroscopy, electron microprobe analysis, scanning electron wicroscopy and analytical electron microscopy w111 all be used to this characterization. Particular attention will be pald to crack tip processes. 
Results Expected, FY 78: It is conceivable that satisfactory results will have been obtalned tron the work on the omega transformation. It is planned to terminate this project and reorientate the research into some aspect of environnentally-induced failure to accentuate the thrust that is being developed on this subject in MRL and Metaliurgy.

The work on hydride precipitation should be expanded to other systems such as Ta-H alloys there, compared to the case of Hb-H alloys, not only do phase diagrem differences exist but also the degree of hysteresis accotmpanying thermal cycling to much reduced.

Work will continue on the embrittlement of Zr and $z r$ alloys by lodine. By the end of this year, a fairly comprehensive understanding of the fallure mechanisms should be developed.

Relationship to Other Federally Funded Profects: A number of Interactions between this project and others on campus have been developed. The work performed in this program may be divided into three. major areas, namely the ome ga phase traneformation, environmentally-induced fallures, and development of sone new techniques in analytical electron microscopy. With regard to the omega phase transformation, as described above, this work is belng performed in cooperation with H. $\mathrm{E}$. Cook (supported by the Unfversity of Illino1s). The interaction stetns from the couplementary nature of our two contributiong--namely the theoretical 1nput from cook and the experiment al input from the principal 1nvestigator. other federally funded work on the orega phase transformation exists, probably the toot signiflcant being that of Professor S. Sass at Cornell University (funded by $0 \mathrm{NR}$ ).

In the case of the environmentally-induced falluxes, a number of strong loteractions extst. The work on hydride prectpitation in $\mathrm{kb}-\mathrm{H}$ alloys is a cooperative study with $H$. K. Birnblam (supported. by ONR). The study of embrittlement of $2 r$ and $1 t s$ alloys by lodine enjoys the interaction of E. N. Pugh. Furthermore, a gtrong interaction occurs between myself and Pugh over hls work on hydrogen embrittlement and stress corroston cracking of $\mathrm{Mg}$ (supported by ERDA). In this vork, my contribution concerss the application of transmssion electron micrascopy to study spectmens prepared from the fracture surfaces. Flaally, the principal lavestigator to a member of the group of researchers carrying out a study to determine the mechanistus of hydrogen embrittlenent in stalnless steels and nickel-1ron alloys (supported by HSF).

Other 1nteractions exist through the expertise that has been developed In conventional transmisston electron microscopy and analytical electron microscopy. Interactions exist between the principal Investigator and (1) C. M. Wayman (NSF-funded) where the nature of the phase transformations in 8 -brass are being determined by use of the energy dispersive X-ray snalyzer; (2) J, E. Greene (Jofnt Services Electrontc Progran funded) where the wicrostructure of thin senfconductor fllms 
grown by sputter deposition is being determined; (3) R. Mehrabian (ARPA funded) where microanalysis of interfaces in composite materials using analytical electron microscopy is being performed; (4) $c$. $A$. Wert where elemental and structural changes accompanying carbide precipltation In $\mathrm{V}-\mathrm{T} I-\mathrm{C}$ alloys are being studied.

Zublications: (Calendar Year 1975)

Hantsh L. Fraser and Ian P. Jones

A Note on the Increase In Usable Foll Thickness in Scanning Transinfssion Electron Microscopy

Phtl. Mag. 31, 225-228 (1975)

H. L. Fraser, N. J. Zaluzec, J. B. Woodhouge, and L. B. S1s

On the Feasibility of Quantitative Microchenical Analysis of Thin Metal Foila 33rd Annual Proceedings Electron Microscopy Soctety, G. W. Batley, ed. (Las Vegas, Nevada 2975) pp. 106-107

M.S. Theses: (Calendar Year 1975)

Scott E. Hughes (H. L. Fraser, Adviser)

A Prelininary Study of the Morphology of Hydride Precipitation in Tantalun October 1975

Ph,D. Theses: (Calendar Year 1975)

None 
Deformetion of Retuforced Metals

Principai Investigator: Marvin Metzger, Ph.D.

Frofessor of Phystcal Ketallurgy

Supporting Agency: $\quad$ J. S. Bnergy Research and Developtnent Administration

Sentor Staff: Marvin Metzger, Professor

Junfor Staff: Prabir R. Bhowsl, Research Assistant

Object: The objective of this work is to develop realistic models of the mechanical behavtor of thetal-antrix fiber or lamellar composttes based on observations of dislocation structures. The central question concerts the princeples governing the behavior of the matrix and the nondeforning phase as affected by their interaction during straining. General nacroscoptc formalisus for compostee are now well known but these do not take account of how the properties of the fndividual components are altered by Interaction and how the nature of the intersction might be predicted from the elastic and plastic properties of the components. This question must be answered for effective prediction of composite behavior In regard to strength and ductility and the design of structure, e.g., how does one predict the optimum interlamellar spacing and would the benefits of attaining it justify an extraordinary effort in processing. The question has heretofoce recelved less attention than it deserved because attention In conposites have been directed mafnly toward finding conpatible fibermatrix combtnations, methods of effective or economical processing and the general properties of the product and also because of certain experimental difficulties with many couposites--e.8., chemical 1rcompatibility of the components which prevents proper thinning for electron microscopy. The objective of thlo work is best realized by concentrating on model syatems which fit experimental requirements, shich include close epacing of the reinforcing phase, ability to vary the spacing and soenability to thinning for microscopy. Current effortg deal with the $\mathrm{NI}_{3} \mathrm{Al}-\mathrm{N} \mathrm{H}_{3} \mathrm{Nb}$ aligned eutectic composite which oatisfies these requitements and has further advantages as a model material in that the operative slip modes of the atrix change with temperature; these overwe1gh. Its experimental diagdvantage of relatively low ductility. Although this naterial would be classed as a high temperature alloy, the 1nformation developed will be of general and not merely of spectfic value.

Results, FY 76:

Most Significant Accomplighments: From intenstve study of dislocation structures to $600^{\circ} \mathrm{C}$, blocked sllp band (p1le-up) or image force models were definitely ruled out and the matrix-reinforcing phase interaction was shown to be coninated by interface strain compat fbility requirements. The avallability of allp wodes able to accommodate this requirement was found to control changes in stress-strain behavior and ductillty with temperature. 
Other Results: A number of specific modes of dislocation crosa-slip and reaction were 1dentifled. These, most of which have not previously been described, account for production of dislocation debris and explain why the matrix strain hardens go rapidly. Faults and dislocations in the $\mathrm{N1}_{3} \mathrm{Nb}$ relnforcing phase were 1dentified. The importance of these detals is that In real composites stress and strain are tnhomogeneous and their properties can not be correctly treated on the basis of imiform deformation.

Reaults Expected, FY 77: In this perlod we expect to deal specifically with the question of nechantcal behavior and dislocation gtcucture versus interlamellar spac1ng, working with composites having both larger and snaller spacings than the $2 \mu m$ material currently under study. In the absence of detalled mechanical and microstructural Iaformation, the model of a blocked slip band leading to the Hall-Petch relation 18 often used to conceptualize this question. However, we will be épecially looking to develop a formalis for predicting the variation of flow strese with Interlamellat spacing bssed on a mote realistic model. A shallet effort wil be made to extend previous observations to tempetatures above $600^{\circ} \mathrm{C}$, the 1nteractiong at the higher temperatures being of interest theoretically to analyze the behavior as the watrix passes through 1 ts naxinum in atraln hatdening rate.

Results Expected, FY 78: We expect to continue along the present lines to test the principles developed to thid point by exanining thelr applicabilfty w1th snother model composite in which natrix deformation nodes are different and fewer in number. Composites which posalbly satisfy the theoretical and experimental requirements are being looked at. Processing to the desired gtructure is a strong constderation here, and prelininary discusalon has been instituted with researchers having expertise and interest in procassing to explore areas of comnon intereat.

Relationsh1p to 0ther Federally Funded Project: Current work Interacts with certain work in Dr. F. D. Lenkey's group at United Technologies Research Center, East Hartford, Conn. Their effortB, company-sponsored, are in developant of aligned eutectic composites for bigh temperature service. They are able to prepare for us special alloys with the structure required for our atudies, and information is exchanged on these alloys and related topfce. Local Interactions are with groups like those of H. Fraser and A. Granato who are concerned with dislocation properties.

Publications: (Calendat Year 1975)

M. Hetzger

Intergranular Corrosion of Single Phase Aluminum as Pitting Phenonenon Journal de Physique 10, C4-387-393 (1975)

Also supported by $A R \overline{0(D)}$ 
M.S. Thes1s (Calendar Year 1975)

James G. Sheltens

Scenting Electron Microacope Study of Pitting on Aluninum in Sulfurte Acid Containing Chloride 1975

Also supported by ARO

Ph.D. Theses: (Calendar Year 1975)

Wone 
The Mechanism of Stress-Corrosion Cracking: Propagation Studies

Princtpal Invertigator: E. Neville Pugh, Ph.D.

Professor of Metallurgleal Engineering

Supporting Agency: U. S. Energy Research and Development Adainigtration

Sentor Staff: E. Neville Pugh, Professor

Junior Staff: Gerhardus K. Koch, Research Agatatant (Terw 2/27/76)

Joseph L. Nelson, Research Asg 1atant

Object: This research is part of a broad study at the Urbans-Champatgo caapus of the mechantsms of environmentally-1nduced frscture of structural naterfals. These fallures, particularly stregs-corrosion cracking (SCC) and hydrogen embrittlement (HE), occur widely in the present generation of nuclear teactors, frequently with serfous consequences. Thus SCC of n1ckel base (e.g., gteav generators) and copper base (e.g., condenser tubes) alloys have led to extended shut-downs; sinflarly, the cracking of austenftic stainless steels has been a comon and costly event in vartous locations wthtn nuclear plants. Bath zircantum and magnesium alloys, used as fuel cladding waterials, are also sugceptible to SCC and HE. These failures were reviewed at a recent ERDA workshop (Germantown, February 24-25, 1976). Significantly, 1t was clear that similar failures can be anticipated in future types of reactors and in other developing energy induatries, particularly in coal gasification and in the harnessing of geothermal energy.

Ef forts to combat environmentally induced fractures are hindered by our lack of understanding of the underlying mechanisms. While some uncertalnty remalns, it seems that $5 C C$ can be grouped into two distinct classes, 1ntergranular ( $\mathrm{I}-\mathrm{SCC}$ ) and tranegranular (T-SCC). The mechan 1sm of the forner to relatively well understood in broad terms, and alnost certainly occurs by preferential anodic dissolution of film-free metal at the crack t1p, exposed by localized plastic deformation, while the crack walis (non-deforming) renain pratected by a passive fillin. The intergranular path of cracking is thought to result from slower repassivation of grain boundartes compared to that of the grain centers, but the factors which determine the repassivation characterlstics of grain boundarieg remain to be established.

T-SCC is poorly understood at present. Fractographic studies indicate that the failures occur by cleavage, that 1s, by brittle mechanical fracture, and thus the chanisn is considęred to be basically different frow that of I-SCC. The cause of eabrittlenent has not been established, but there is considerable interest, and controversy, in the possibility that 1 t 18 due to hydrogen absorption-that 18 , that T-SCC is a forn of HE. It $1 s$ well established that HE occurs in certain uaterlals, e.g., high 
strength steels and the refractory metals such as vanadium and nfobium, and that it can result from internal hydrogen, introduced by cathodic or high-temperature gas chsrging, or during exposure to external gaseous hydrogen. Two mechantsms of $\mathrm{HE}$ are currently being advocated, the first postulating that hydrogen reduces the bond strength of the host aaterial (decohesion model), and the second proposing that cracking proceeds by the formation and fracture of brittle, stress-tnduced hydrides. It is possible that each of these mechanisus may operate in partfcular caseg, or, alternatively, that only a single mechanise is responsible for all cases of $\mathrm{HE}$.

The present project is concerned prinartly with the mechanism of T-SCC, and, because of the possible involvement of hydrogen, with that of HE. The studies are being carried out on the ICP alloys of nagnesium, t1tanium and $21 x \cos 1 u m$, and on an Al- $\mathrm{Zn} \rightarrow \mathrm{Hg}$ alloy. Currently, the naln experimental techniques are fractography and acoustic emlagion, the latter being used to Investigate the fuportant question of whather crack propagation 18 continuous or discontinuous.

Results, FY 76:

Most Sigmiflcant Accomplishments: The most algatficant finding was made In studies of SCC and $\mathrm{HE}$ of $\mathrm{a} \mathrm{Kg}-\mathrm{Al}$ alloy. Our earlier gtudles have shown that this alloy tundergoes cleavage-like T-SCC in aqueous chloridechromate solutions, and also fallg transgranularly by 1ntermal hydrogen embrittlement (IHE) after exposure of unstressed apecinens to this solution, and by gaseous hydrogen etrbittlement (GHE). In the past year, SEY and electron-diffraction studiee have shown that a brittle layer of $\mathrm{MgH}_{2}$ extsts at the fracture surfaces produced by $\mathrm{SCC}$, IHE and GHE. Tests in whtch clean surfaces, produced by rapid ductile fracture In the environment, were expoged to the aqueous or gaseous environnent provided no evidence of the hydride, auggesting that it is atress-induced during slow crack growth in SCC and both fortne of HE. These observations are of particular significance since they suggest that T-SCC, in this systed at least, $t s$ a form of $H E$, and that it involves the formation of stress-induced hydrides.

Significant progress has also been made in the study of Th-8Al-1Ho-1V, * "near-a" cormercial alloy contalning -5 percent $B$. GHE was found to occur in 1 atmoophere dry hydrogen in spectmens contaloling continuous $B$, but not in those in which the $B$ phase is discontinuous. Cracklng was obsetved to follow the $\alpha-\beta$ Interface and electron-ricroscope (SEM and TEM) and electron-diffraction studies established the presence of a brittie layer of $\mathrm{TLH}_{2}$ at the fracture surfaces. The solubility and diffusivity of hydrogen is considerably greatex in $B$ - than In a-T1, and thus our observations support the view that hydrogen enters via the $\beta$, forms the brittle hydride in the $\alpha$ at the $\alpha-\beta$ interface, and peratts crack propagation through this brittle phase. Fractographic and acoustic-enission studies Indicated that propagation is discontinuous. 
Other Results: A study has also been tade of the SCC of T1-8A1-Mo-1V . The alloy underwent ctacking in aqueous chloride solutions but the cheracteristics of fallure were aigniflcantly difEerent fron those of GHE. Thus cracking in aqueous solution occurred in specimens in thich the Bphase was efther continuous or disconcinuous, and took place by (10I7) cleavage through the a-phase rather than following the $\alpha-\beta$ interface. Electron diffraction provided no evidence for the presence of hydride at the stress-corrosion fracture surfaces, and thus tt can be aerlously questioned whether hydrogen plays any role in the gtress-corrosion fracture process. On the other hand, it is possible that hydrogen is able to ditectly enter the o-phase from the aqueous solution ( $\mathrm{pH}-1.7$ ), and becauge of the higher fugacity, that 1t preclpitates as a surface layer of hydride which ts too shallow to be detected by our electron-diffraction technique. Such a layer might concelvably lead to enbrittlement of the a-phase, but $1 \mathrm{t}$ is clear that further work is necessary to provide support for a hydrogen model in this system.

We have continued our studies of SCC of an Al-Zn-Mg alloy. ThLs alloy generally cracks intergranularly, but our work during the past year established that T-SCC can occur if I-SCC is avoided. The transgranular fracture gurfaces have been shown to be cleavage-like, sintlar to those in other cases of T-SCC, and the presence of striations 1ndicate that propogation is discontinuous. Significancly, observations to date suggest that the fallure results from the entry of hydrogen generated by reaction of woter with aluminum.

Results Expected, FY 77: It was seen in the preceding section that SCC and $\mathrm{HE}$ in the $\mathrm{Mg}-\overline{A l}$ alloy were found to be associated with the formation of $\mathrm{MgH}_{2}$. Further progress in understanding the mechantsu of these fallures requires a more detalled knowledge of the atructure and morphology of the hydride layers at the fracture surfaces, and of hydride preclpitation in this alloy, per se. These aepects are now being lnvestigated by transnisston electron microscopy in collaboration w1th H. L. Fraber. It is hoped that these atudtes will resolve several apparent anonalies which currently exist. For example, SCC 1n this alloy occurs by claavage on \{3140\} planes, wherees IHE and GHE produce transgranular fracture surfaces which are uneven on a microscoplc scale, exhlbiting a corrugated appearance, and which do not tend to be in $\{3140\}$ planes. It may be speculated that these differences result because fractuze in SCC occurs on the cleavage plane of a thick hydride, but that the HE processes involve cracking along the habit planes of thin plates.

It is antic1pated that the characterization of $\mathrm{T}-\mathrm{SCC}$ in the Al-Zn-Hg alloy will be completed in FY 77. In particular, we expect to obtain the orfentation of the fracture plane, and to comare $t t$ with those for T-SCC In the other FCC alloys, a-brass and austenttic stainless ateel, which are being determined in parallel programs (Bee Relationship to other Federally Funded Projects). It is hoped that eone generalfzations will emerge, It was aeen above (FY 76) that the fracture surfaces of this 
alloy are striated, indleating that propagation 15 discontinuous. Acousticemisgion studies are in progress to provide further evidence for this impottant conclusion. In addition to providing evidence for discrete emisstons, this technique allowg the determination of the time intervals between crack-advance events. Thus knowing the crack-advance dietance from fractography, 1.e., the Interstriation spacting, an estimate can be made of the overall crack velocity which can be compared with directly measured values. Such a comparison would provide an impartant test of our vietrs.

In FY 77, we plan to begin an investigation of the fallure of zircontur alloys in lodine vapors at elevated temperatures. This is a transgranular fallure which hes occurred in zircaloy fuet cladding, lodine befing a fission product, but the prime notivation for these studies is mechanistic and relates to the role of hydrogen in embrtitlement phenomena. It is considered that the occurrence of HE In a vide variety of naterials otens from the fact that hydrogen 18 present in commonly encountered environdents and also because $1 \mathrm{t}$ is highly mobile in metals at amblent temperatures. Thus similar embrittlement might be expected to reaule from certain other spectes if they were present in sufficient concentration and if they were suffictently mobile. The lodine-1nduced cracking of zircaloys is thought to be an example of such a fallure. Because of our interest in the possible role of hydrides in HE and T-SCC, a prine objective will be to identify lodioes in falled opecimens by means of tranemission election microscopy and electron diffraction. These studies will again be carrfed out In cooperation with H. L. Praser. An advantage of this approach is that lodine can be detected by electron-optical techniques, e.g., the mitroprobe and Auger spectrogcopy, fn contrast to hydrogen.

Results Expected; FY 78: It 18 evident from the preceding sections that the program is toving logically into a study of the role of atress-1nduced hydrides in embrittlement phenomena. Thus it is antlctpated that effort In FY 78 will be centered increasingly on the study of hydride formation In a number of materials, Including a-tItanlum, $\mathrm{Hg}-\mathrm{Al}$ and posstbly $\mathrm{Al}-\mathrm{Zn}-\mathrm{Mg}$.

Relationship to Other Federaily Funded Projects: It was seen in a preceding section (object) that there are eeveral forms of environmentatly induced fracture, I-SCC, T-SCC and HE. Both forme of SCC occur in a-brasaes in aqueous atmonia and are beling studied by the Principal Investigator (and two research asistants) tnder an ARO grant. The Princlpal Investigator, sharing a postdoctoral fellow w1th C. J. Altstetter, is also taking part In a NSF-funded atudy of T-SCC and HE of austenitic stainless steels; this is part of a larger, linteractive program on the HE of Fe-NI-Cr alloys (w1th H, K. Birubaum, H. L. Frager and R. A. Yeske). The phenomenon of $\mathrm{HE}$ is also belng studied by H. K. Birnbaum In nioblum, and there is useful 1nteraction between this work and the present profect. The Principal Investigator ig aloo developing strong interaction with H. L. Fraser on transmission electron microscopy of hydrogenated foils, and with $R$. A. Yeske on the Eracture-mechanles approach to the characterization of crack propagation. It is anticipated that further 1nteraction 111 develop 
with a new faculty menber, $R$. Mehrablan, on the influence of new processing methods on stresg-corrosion behavior; for exsuple, we plan to pursue the effects of thiting and raptdiy solidifying shallow surface layers by means of laser heating. Thus it ts evident that a signiffcant thrust is beling developed in the area of SCC and HE. Further, these studies are part of a broader program within the MRL on the bohavior of hydrogen in motals.

\section{Publications: (Calendar Year 1975)}

D. G. Chakrapant and E. N. Pugh

The Transgranular SCC of a Mg-Al Alloy: Crygtallographlc, Fractographic and Acoust1c-zatseion Studie日

Hetall. Transactions 6A, 1155-1163 (1975)

D. G. Chakrapant and E. N. Pugh

On the Fractography of Transgranular Stress-Carrosion Fatlures Ic a Mg-Al Alloy Corroston 31, 247-252 (1975)

J. L. Nelson and E. N. Pugh

The Occurrence of Transgranular Cleavage-L1ke Fracture in an Al-Zn-Mg Alloy During Tenatle

Metall. Transactions 6 A, $1459-1460$ (1975)

H. Gabe1, J. A. Beavera, J. B. Woodhouse, and E. N. Pugh

The Structure and Composition of Thick Tarnish Filne on Alpha-Phase Copper Alloys Corrosion (accepted)

Also supported by ARO-D-G127

D. G. Chakrapan1, G. H. Koch, and E. N. Fugh

on the Mechanlom of SCC in a Hg-Al Alloy

Proceedings S1xth International Congress on Metallic Corrosion, Austral1a, 1975

(to be published)

D. G. Chakrapan1 and E. W. Pugh

Hydrogen Embrictlenent in a Hg-Al Alloy

Metall. Transactions (accepted)

M.S. Theses: (Calendar Year 1975)

None

Ph.D. Theses: (Celendar Year 1975)

D. G. Chakrapani (E. N. Pugh, Advfser)

Transgranular Stress-Corrosion Cracking of a Magneslum-Aluminum Alloy

Hay 1975 
Precipltation in Refractory Matal Alloys

Principal Invest1gator: Charles A. Wert, Ph.D. Professor of Physical Metallurgy;

Head, Department of Metallurgy and Mining Englneering

Supporting Agency: U. S. Energy Research and Development Admintatration

Sentor Staff: Charles A. Wert, Professor

Jusior Staff: Stephen H. Bruewer, Re6earch Assistant

Theodore R. Wilken, Research Assistant (Term 1/22/76)

Dennis Beggs, Fegearch Aselstant

Object: The refractory netal compounds-oxides, nitrides, carbides and hydrides-are 1.portant in bulk, but they are even more fmportant as Inclusions in metals since they control many of the nechanical properties. A wide varlety of coupounds exists and the avallable ranges of composition and temperature are so great that extrene selectivity must be exercised to keep experiments with1n bounds. Three spectfic problems have'been tackled in the past flve years, two of whth are still active and one of which has reached a stage of conpletion. The firgt is concerned with carbides in $V$ and $\mathrm{Nb}$, the second with hydrides in $\mathrm{V}$, Nb and $\mathrm{Ta}$ and the third with oxides of $w$.

Carbides In vanadium and nloblum are Important hat dening agents. Mearly twenty years ago, carbideg in niobium were found to give excellent high temperature 8 trength; ay flrst introduction was in asgociation with the Pratt and Whttney nuclear-powered aircraft project. In that work, there was no tine to do anything but try a wide sertes of alloys and"rio detailed nicro-structural exanipation of carblde-hardened alloys was made.

Later we began to examine carbide formation in binary alloys of vanadium and carbon. Rap1d quenching of alloys carbonized above $1000^{\circ} \mathrm{C}$ permits apprectable quantities of carbon to be cetained in solution (up to 0.5 at.z). Aging in the teaperature range $200-800^{\circ} \mathrm{C}$ produces a sequence of two carbides. The first is a fine-scale coherent carbide on (310) habit planes of the host metal. Formation of this carbide is accompanied by apprectable strengthentng of the alloy. Prolonged aging above $500^{\circ} \mathrm{C}$ results in transformation of this carbide to the hexagonal $V_{2} C$, whose basal plane attempts to ratch the (110) plane of the host aetal. Even though constderable nismatch occurs on this plane, the alloy is soft in this state, and the binary $v-C$ and $N b-C$ alloys are not practical for high temperature service.

Ternary alloys $V-r 1-C$ are now being examined to determine the cryatalline nature of the carbides and the range of effective age-hardening. Alloys of $1 \%, 5 \%$ and $15 \%$ T1 have been prepared, carburized and examined partially. Alloys at $18 \mathrm{~T} 1$ are little different fron the plain binertes, so no further work 18 planned for this composition. 
Alloys of $5 \%$ T1 produce a striking new effect--a high temperature carbide, coherent on (100) planes, ts formed around $1000^{\circ} \mathrm{C}$, where it 1s renarkably stable. Three types of Investigation are under way: (1) chentcal analysis of the carbide is being attempted using the non-diaperstve detector of the electron microscope, (2) the range of stability over time and temperature ts being determined, and (3) mechantcal propertlee of the alloy will be measured as a function of sging times and temperature.

The Important feature of this alloy is the posstbility that finely-dispersed coherent carbides may be formed in vandisu at tempratures well over $\mathrm{Tm} / 2$. Sintlar effects way be seen In $\mathrm{Nb}-\mathrm{TI}-\mathrm{C}$ alloys. He oxpect to extend the work to higher concentrations of $T 1$ and to quaternary alloys such as $\mathrm{V}$-T1-Cr-C. The path to go has been well exploted by Profeasors Jack of Newcastle-on-Tyne and Honeyconbe of Cambrldge, who have shown remarkable strengthening of the bcc 1ron phase of low-alloy steels hardened by judiclously chosen altride and carbide precipttates.

Alloys of kb and $V$ are certain eventually to be important in high temperature service, so the nature of the carbides which strangthen then and ranges of conposition, temperature and compatibility wth hydrogen nust be determined.

Results, FY 76:

Most S1gnificant Accomplishment: Refractory metal compounds, especially axides, are luportant in Industrial production of metals and alloys. Because of wide dfversity in compostion and stabllity of oxfdes, conditions of oxide reduction to the metallic state are almost unique material by material. We have concluded a etudy of reduction of tungeten oxide to tungaten metal over a wide range of reduction conditions and of additives found useful in comercial practlce. The work results fron a long series of investigations between $C$. Wert and the Weatinghouse Lamp Division on production of lamp filamente. The present tork to a collaborative effort between $H$. Sell and $b$. Morcon of Wegtinghouse with C. Wert, Ted WIlken and $\mathrm{J}$. Woodhouse of the Uatverstty of Illinols. It was a nassive study--sone 700 onlde and metal powders were exanined.

Commercial tungeten for filanente io nearly pure tungsten--1t contalns only a few hundred ppm of potassium, silicon and aluminum. Even so, these addicives are laportant in the development during processing of an interlocking elongated grain structure whlch strengthens the fllament. The wetalitc elements are added as oxides and salte at an fnternediațe processing stage-usulily when the tungsten $\mathrm{l}_{\mathrm{g}}$ an oxide or a paratungstate.

This investigation had the goal of determining the nature of intermediate steps durfing the reduction of $\mathrm{WO}_{3}$ to $\mathrm{a-W}$ and the role of the dopant compounds of $\mathrm{K}, \mathrm{St}$ and $\mathrm{A} 1$. Observations were made of the stolchiometry, crystal structure and appearance of both Internedtate oxides and the final nearly-pure vetal. Observational techniques included chenical analysis, analys of the reducing gas, X-ray structure determinations and scanning electron microscopy. 
Starting materlals were all bastcally $\mathrm{W}_{20} 0_{59}$, a sifghty off-stotchlometry $\mathrm{WO}_{3}$. F1ve different mater1sls were used: "pure" $\mathrm{W}_{2} \mathrm{O}_{59}$, the oxide "commerctally-doped" with compounds of $\mathrm{X}, \mathrm{Si}$ and $\mathrm{Al}$, and the oxide doped selectively with either $\mathrm{StO}_{2}, \mathrm{Al}_{2} \mathrm{O}_{3}$ or $\mathrm{K}_{2} \mathrm{S1O}_{4}$. All reductions vere carried out over the range $500^{\circ} \mathrm{C}$ to $900^{\circ} \mathrm{C}$ in hydrogen gas of controlled initial water vapor content.

Three maln reduction paths are observed.

1. $\mathrm{W}_{20} \mathrm{O}_{59} \rightarrow \mathrm{WO}_{2.90}+\mathrm{B}-\mathrm{W} \rightarrow \mathrm{\alpha}-\mathrm{W}$.

This reaction occurs at lower temperstures and for the purer materials. It 18 not of practical importance.

2. $\mathrm{W}_{20} \mathrm{O}_{59} \rightarrow \mathrm{WO}_{2,90} \rightarrow \mathrm{wO}_{2} \rightarrow \alpha-W$.

Th1s reaction occurs at Intermediate teuperatures and 18 of marginal practical importance.

3. $\mathrm{w}_{20} \mathrm{O}_{59}+\mathrm{wO}_{2.90}+\mathrm{wO}_{2.72}+\mathrm{wO}_{2}+\alpha-\mathrm{H}$.

This is the important reduction path for production of comerctal tungsten powder.

The end-product $a-w$ of process 3 ts the most ioportant practically. It produces metallic crystallikes of mixture of sizes. Important2y, the larger crystallites do not possess smooth facets, but are dimpled and rough. We belleve that the potasstum-aluminin-silicon compound importent to high-temperature creep resistance of lawp filaments 18 carried along in these diwles and holes developed during reduction.

Sorting out the myriad of observations and establishing valid general conclustons has been an enormous task. But it is now completed and we Intend to begin on the next stage--determination of the nature of the important potassium-besring compound present in the ctystallites. This problen is referred to again in FY 78.

Results Expected, FY 77: Three aress are ripe for furcher investigation: (a) Carbide strengthening of ternary and quaternary alloys of $\mathrm{V}$ and $\mathrm{Nb}$. (b) Resolution of discrepancies in thermodynamic and kfnetic features of the $V-H$ and $V-D$ alloy systens. (c) Extension of dopant techniques strengthening of $W$ to other bcc metals. During FY 1977 we expect to work on the first two of these.

Ranges of stability of coherent fine-scale mixed carbides will be determined In $v$. These alloys will be made by carburizing specinens of appropriate $T i$ and $C x$ conposition, followed by quenching and aglng in the temperature range $1000^{\circ} \mathrm{C}$ to above $1200^{\circ} \mathrm{C}$. Concentrations of $\mathrm{Cr}$ and $\mathrm{Ti}$ will be in the range 5 to 15 at. $z$. The effect of these carbides on the high temperature gtrength will be determined. 
Experiments in alloys of tron conteining precipttated nitrides such as ( $\left.\mathrm{Fe}, \mathrm{No}_{\mathrm{y}}\right)_{16} \mathrm{~N}_{2}$ and $\mathrm{Fe} \mathrm{V}_{\mathrm{Y}} \mathrm{C}$ have ohown that apprectable strengthentug of the bce natrix occurs for precipitates in the sub-micron range. The carbides are the tore effective as the particle size dacreases. In the ferritic ateels, preclpitates as small as $20 \mathrm{~h}$ hin size can be produced, partly by we of the $\gamma$ a transformstion. Appreclable strengthening occurs to temperatures of $600^{\circ} \mathrm{C}$ to $800^{\circ} \mathrm{C}$. We can produce carbides as small as these in $V$ even without the ald of a $\gamma-a$ transforration. But we are alning at auch higher temperatures and way have difficulty preventing carbide coersening and consequent softening. But the strong tendency for the alloy to choose a carbide of such conposition that near-coherency of lattice matching occurs gives hope that success can be achleved at least to $1000^{\circ} \mathrm{C}$.

Results Expected, FY 78: An attractlve prospect 1g the strengthening of bcc metals other than tungsten by "vold" hardening. Espec1ally attractive is the possibility of improvenent in high temperature creep reatstance by tmmobilization of grain boundarles.

Tumgsten lawp filawents contain elongated fralng etabllized by "volds". These volds, however, are not aluply collections of vacancles; they are filled with potassium carried over in sone manner from the early stages of reduction of the doped oxides. Potassiun must be nearly ingolubie at high temperatures and the volds are produced on the first heating of a filament by volatilization of particles of potasolum metal or a potassium compound which is above its critical point.

Can this be done for other bec netals? The metallurgy is foruldable, Conditions and levels of dopant wot be found. The oxfdes must have the correct level of stability to permit reduction at tenperaturea low enough so thet the dopant is not fully volatized during production of the metal. Then the crystallites of metal powder must apparently have holes or dimples sufficlently deep to trap the dopant during the sintering atepa.

The first metal to try is vanadiun. Its oxides have relatively low stability in contrast to those of nioblum and tantalun, which are quite stable. Even for vanadium, the task is formidable. Sone forty yeara of commercial practice brought tungaten to its present atate and aome fifteen years of Investipation were required to understand the hardening mechanism, But once the transmisstion electron nicroscope, the scanning electron microscope and the Auger spectroneter were brought to beax on the subject, the answer came quickly.

Wtth this background of understanding, we should be able to see if the techntque has any promise for other bcc's in a reasonable time.

Relationshlp to Other Federally Funded Projects: Hydrogen, deuterium and tritium are important to the use of refractory metals. They bave huge oolubllity at hIgh temperatur in $V$, ib and Ta and cause embittlement. At low temperatures where hydrides (deuterides and tritides) form, 
embrittlement ig even more of a problen, even at low gas concentrations. In other metals such as $w$, Ho and many steels, hydrogen may be sparingly soluble, but nay cause enbrittlement even so.

My interest In these problems developed in the late 1960's ftom two sources: (1) A long series of discussions with C. P. Fiynn and M. Stonehan as they developed a diffusion theory particularly applicable to IIght elements. (2) Several gummers at the Sclence Center of Rockwell International where we began to work on mechanlcal aspects of alloys contafning hydrogen-partly because of the Interests of Rocketdyne in high presaure atorage of hydrogen and its use as a fuel fn opace vehtcles.

Almost at the sane time $\mathrm{H}$. Birnbaum developed an interest in hydrogen diffusion and gradually the activity at Urbana has grown to include many metallurgy and physics faculty. My continuing part of this activity within MRL is now only wodest (one graduate student) and is centered in trapping of hydrogen by oxygen, nitrogen and carbon atows $1 \mathrm{n} \mathrm{V}$ and $\mathrm{Ta}$. Th1s is accomplished by determination of the effect of impurity additions (1n the range 0.1 to $1.0 \mathrm{at} . \boldsymbol{z}$ ) on both the solubtlity of hydrogen (and deuterfum) and the rate of formation of the hydride (or deuteride). A long sertes of Investigations (combined with published data) shows the following for $\mathrm{V}$, Nb, and $\mathrm{Ta}$ :

1. For these three metals the heats of golution, $\mathrm{H}_{\mathrm{g}}$, of the hydride are in the range $0.10 \mathrm{eV}$ to $0.15 \mathrm{eV}$. (1.e., about 2000 to 3000 cal is required to dissolve a mole of the metal-hydride in the metal). Likesise for the deuteride.

2. Dissolved oxygen greatly slows the rate of formation of the hydride (or deuteride).

3. Dissolved oxygen does not appear to affect the equilibriun solubillty of hydrogen or deuter lum. Thus the binding energy of $h$ or $D$ atoms to oxyBen in a given metal must be leas than $\mathrm{H}_{8}$ for that metal, but apprec1ably greeter than zero.

4. H and $D$ have the same solubility in $\mathrm{Nb}$ at low temperatures. Also in $\mathrm{Ta}$.

5. For $V$, published results are in disggreenent.

a. 0xygen does retard fotwation of hydrides or deuterides.

b. Heats of solution for both isotopes are in disagreement.

c. H and D may or may not have the same solubility at low temperaturea,

The only serlous remaining 1asue is thus for $H$ and $D$ in vanadium. D. Westlake at Argonne, $T$. Scott at Anes and $I$ are the chtef U. S. Investigators whose results do not fully agree, probably because of the extraordinary 1mortance of trace 1mpurities. By exchange of specinens and by continued attention to 1mpuritieg, we expact to resolve this Issue. 
The assoctation with the Sclence Center at Rockwell International continues. Jolnt experinents on the elastlc properties of lib-H alloys with D. Thompgon and Otto Buck are being carrled out on a grant from NSF, Hydrogen produces large changes in the elastic constants of $\mathrm{Kb}$, Ta and $V$. Changes for sone of the fundanntal constants are positive on hydrogen addition, for others negative. Theige results were interpreted ta be a reaclt of mechanical relaxation (1.e., rearrangements which lead to 1uternal friction). We are attempting (1) to check the published results, (2) to oee whether the changes in elastic constants may not be relnted to electronic effects rather than mechenical relaxations and (3) to messtre the third order elagtic constants to find the antaxwonlc1ty of the site in which the hydrogen stts.

Publicationg: (Calendar Year 1975)

Philippe Lecoeq and Charles Wert Equilfbrium in Hydride Foreation in Tantalum Thin Solid Ftlms 25, 77-84 (1975)

M.S. Theses: (Calendar Year 1975)

R. W. Levis (C. A. Wert, Adviser)

The Solubility of Hydrogen in Vanadium August 1975

T. W1lken (C. A. Wert, Adviaer)

The Morphological Structure Produced During Reduction of Blue Tungsen Oxide to Tungsten Hetal

Hay 1975

Ph.D. Theges: (Calendar Year 1975)

Norte 
ED-02-01-03-0 Physical Properties

Dielectric Solids

Principal Investigator: David A. Payne, Ph,D.

Assistant Professor of Geramic Engineer 1ng

Supporting Agency: U. S. Energy. Research and Development Administration

Sentor Staff: David Payte, Asslstant Professor

Juntor Staff: Roberta M. Fay, Research Assiatant

Byung Ko, Regearch Assiotant

Sang Park, Graduate Student

Object: A new project was Inftiated in July, 1975 for the study of dielectric solids. Dielectric solids are a technologically important class of materials which are used in a variety of applications, 1ncluding electrical insulation and transuission, capacitive components, energy storage and conversion, transducers, thermal controls and detection, imsing, displays, information storage and wodulation. The profect afms to contribute to a fullex fundanental underatanding of structureproperty relations by (1) preparing new highly polarizable materfals, and (2) characterizing the dielectric behavior in both aingle cryatal and . polycrystalline form.

All crystalline solids may be classtifted according to thelx symmetry. of the 32 crystal classes (polnt groups), 11 are centric and can not be polar. of the remaining 21 acentric classes, 20 are plezoelectric $(1, e, a$ mechanical stress induces electrictity and conversely), and 10 have anique polar axis along which they are spontaneously polarized. The value of the spontaneoug polarization is dependent upon temperature, and if the temperature of the dlelectric is altexed, a change in polartzation occurs which gives ilse to a change in surface charge. This 18 known as the pyroelectric effect. If a component of the spontaneous polarization may be reversed by an applied electric fleld, this is known as the ferroelectric offect. Quartz is a well-knowr plezoelectric, but is not pyroelectric. The mineral tourmaline is highly pyroelectric (and therefore piezoelectric), but not ferroelectric, since electric breakdown occurs before polarization reversal. The synthetic coupound BaT10 3 is perhaps the best knowi ferroelectric (and therefore pyroelectric, and plezoelectric).

Concerning energy gystems: pfezoelectrics are uaed to transduce mechanical work Into electric potential; pyroelectrics convert thermal changes into electric current; and ferroelectrics (whtch are highly susceptible to electric field changes) are used to store electric energy. We sre searching for new and betzer materisls and are currently investigating (1) piezoelectr1c $\mathrm{Bi}_{2} \mathrm{WO}_{6}$ and (11) pyroelectric $\mathrm{Pb}_{5} \mathrm{Ge}_{3} \mathrm{O}_{11}$ which is also fertolectric and optically active. In addition, the insulation rellability and dielectric strength of Barto, is being investigated with regpect to stoichionetry, purity and structural order. 
It is our belfef that the study of single crystal dielectric materials will reach a level of understanding where an interptetation of the electric behavior of well-characterlzed polycryatalline systems should be possible in terms of modifted aingle cryatal propertles. This investigation 1s concerned with this general probles and intends to explore the role of Internel boundaries upon the dieloctric behavior of coramic systems. As strch it is part of a larger program of research investigating the effects of cerantc nicrostructure upon the electrical characteristics of polycrystalline materials.

Results, FY 76:

Most Significant Accomplishments: The most significant accouplishment to date has been in the area of materials proceasing and fabrication etwdies. We have been successful in putting to lomediate practical uge the inforwation genterated frotn our synthesls studies on $\mathrm{Pb}_{5} \mathrm{Ce}_{3} \mathrm{O}_{11}$ and $\mathrm{Pb}_{5}(\mathrm{Ce}, \mathrm{S1})_{3} \mathrm{O}_{11}$. This class of low melting polnt high dielectric constant ferrolectric materials is of considerable interest as a sintering ald for $\mathrm{BaTHO}_{3}$ cetanlcs. Barlum titanate based capacttore and transducers are normally fired between 1300 and $1400^{\circ} \mathrm{C}$. By sintering in the presence of a 11quid phase, rapid consolidation will occur through surface tension and capillary forces, if the liquid wets the solid particles. Dense dipharic $\mathrm{BaT1O}_{3}-\mathrm{Pb}_{5} \mathrm{Ce}_{3} \mathrm{O}_{11}$ ceranics have been succesafully prepared by this technique of liquid phase sintering, at temperatures significastly lower than $1400^{\circ} \mathrm{C}$ and close to $750^{\circ} \mathrm{C}$. This technical accomplishnent means not only substantial energy savings will be realized in the electrical ceranico Industry by reduced thermal processing, but also alleviatea the dependence on expensive strateglcsily toportant prectous metals which are used as co-sinterable Internal electrodes in integrated couponents.

Other Results: Lead gernanate is trigonal (3) at roon temperature, with a ferroelectric-paraelectric (3/a) transition at $177^{\circ} \mathrm{C}$. The polar axis 1s along the $C$ direction, and the phase transition moy be noved towards toom temperature by $\$ 1$ substitution. Experimenes in this laboratory have verifled that lead germaniuw sillcate glasees may be forned and subsequently recrystallized. The dielectric properties of both sintered and recrystallized $\mathrm{Pb}_{5}(\mathrm{Ge}, \mathrm{S1})_{3} \mathrm{O}_{11}$ compositions have been charscterized and the phase transition behavior of lead germantuth silicate appears to have a high degree of second order. Th1n plate-11ke cryatals grow from the glass, and In thin layers the polar axis is perpendicular to the sanple surface. The Ioplications are extrenely encouraging for the fabrication of large surface area pyroelectric detectors by glasg coating techniques, Besides thermal control devices, the posstbility of efficient pyroelectric generators is concelvable at temperatures below the Debye temperature.

The growth of oingle crystal $\mathrm{BI}_{2} \mathrm{WO}_{6}$ and $\mathrm{BI}_{2} \mathrm{MOO}_{6}$ is being atcenpted. Intial experimenta are underway by the hydrotherual nethod, flux growth, double decomposition, vapor transport and the gel method. Spectal crystal growth equipment has been designed. The system $\mathrm{BI}_{2} \mathrm{O}_{3}-\mathrm{WO}_{3}$ has becowe of 
cons1derable technological interest in recent years due in part to the discopery of new solfd state materials autable for a variety of fmproved energy applications, ranglng from catalysis to galvanic energy cells and dielectric devices. Even thotgh there appears to be some question conceralng the number and types of stable phases present in this syotem, there is little doubt that the most refractory compound is b1sinuth tungstate $\left(\mathrm{Bi}_{2} \mathrm{WO}_{6}\right)$, a compound which me1ts congruently at $1080^{\circ} \mathrm{C}$. Large single crystals can be pulied from the stolchlometric melt, but unfortunately they crack on cooling, with polycrystallization of the boule being attributed to a destructive phase transformation at approximately $935^{\circ} \mathrm{C}$. Consequentiy, little is known about the intrinsic properties of strain free alngle crystal $\mathrm{Bi}_{2} \mathrm{WO}_{6}$. The roon temperature cryatal structure of $\mathrm{B1}_{2} \mathrm{WO}_{6}$ is or thorhomb1c ${ }^{2}$. Tumgsten $1 \mathrm{~s}$ displaced $0.44 \&$ from the center of the oxygen octahedra along the polar axis; and assuming complete 1onfc bonding a theoretical spontaneous polarizacion value of $P_{s}=0.42 \mathrm{c} / \mathrm{m}^{2}$ can be calculated. This is nearly twice the value for BaTio 3 and indicative of the potential use of $\mathrm{BI}_{2} \mathrm{WO}_{t}$ in plezoelectric, pyroelectric, and possibly ferroelectric applications. Coupled with the high refractive index assoc1sted with dense highly polarizable structures, a definite poasibility Is apparent for property improvement in acoustooptic and electrooptic devices. Therefore, a need exists for the growth and evaluation of single crystal $\mathrm{B1}_{2} \mathrm{HO}_{6}$.

So far we have been able to recrystal11ze $\mathrm{Bi}_{2} \mathrm{WO}_{6}$ by the hydrothermal method at temperatures significantly lower thon the polyworphic transition. Optical eremination of 1 mon size crystals (rectystallized at $400^{\circ} \mathrm{C}$ ) Indicate the crystals were strain free and contained no apparent donains. X-ray results were in excellent agreement with previous data. Single dopaln crystals were placed in extinction in cross polarized $1.1 \mathrm{ght}$ and heated on the hot-stage nicroscope. No phase transformation was observed at $935^{\circ} \mathrm{C}$. With slow heating rates, optical transmission became apparent only at $900^{\circ} \mathrm{C}$ within locallzed volumes, and the crystals became completely transparent at $1010^{\circ} \mathrm{C}$. On slow cool1ng, a phage transformation was not observed at $935^{\circ} \mathrm{C}$, but rather at $860^{\circ} \mathrm{C}$, and below this temperatore the crystals were found to contaln many domalns. Hysteresis in the phase transformation was agaln observed on recycling the temperature, and this time the crystals catastrophtcally cracked at $1010^{\circ} \mathrm{C}$. The fracture energy was auficlent to lift the crystals off the wicroscope stage and out of the field of view. It is interesting to note: the transformation observed at $860^{\circ} \mathrm{C}$ with decreasing temperature for hydrothermally grown single crystal $\mathrm{B1}_{2} \mathrm{WO}_{6}$, colaclded with the previously observed temperature for crack intelation In Czochralski boules. Apparently, domain formation was insufficient for relieving transformation strain (resulting from the prototyplc-polar transitfon); and elastlc fallure subsequently occurred. Strain free single comain $\mathrm{BI}_{2} \mathrm{HO}_{6}$ crystals (1 mm) were grown by the hydrothermal method, at temperstures significantly below the polymorphic transfornation. No doubt larger crystals $(1 \mathrm{~cm})$ may be grown $1 \mathrm{n}$ the fucure, similar to the developments made for a-quartz. This could give rise to sone interesting electronechanical energy conversion devices. 
Another aspect of our research actfulty has been concexned w1th thin-film and thin-1ayer capacitive devices. For example, $\mathrm{B1}_{2} \mathrm{WO}_{6}$ can be sputtered asto substrates, and when annealed in alt at $250^{\circ} \mathrm{C}$ the films are highly crystall1me. B1smuth tungstate belongs to the bismuth titanate $\left(\mathrm{BI}_{4} \mathrm{Ti}_{3} \mathrm{O}_{12}\right)$ fandiy of materfals, of general formula $B 1_{2} \mathrm{M}_{n-1} \mathrm{R}_{n} \mathrm{O}_{3 n+3}$, which consist of $\mathrm{Bt}_{2} \mathrm{O}_{2}$ layers Interleaved by $\mathrm{K}_{n-1} \mathrm{R}_{n} \mathrm{O}_{3 n+1}$ perovskite like layers. For $\mathrm{BI}_{2} \mathrm{HO}_{6}, \mathrm{n}=1$; and if the layered structure deposits epttaxially with the polar vector normal to the substrate surface, this configuration would be extremely sulted for acoustic delay line applications. We have also determined how to evaporate $\mathrm{BL}_{2} \mathrm{O}_{3}$ Insulating films, and are Invertigating the effect of $\mathrm{BI}_{2} \mathrm{O}_{3}$ coatings on doped $\mathrm{ZnO}$ single crystals of varlous resistivities, Electrical measurements will contribute to our underatanding of varistor behavior in complex polycrys talline heterogeneous cetanics which exh1bit non-ohmic current-voltage characteristics stmilar to back-to-back Zener dlodes. A model varfstor system consists typlcally of a wajor dispersed phase of gemiconducting $Z$ nO grains which are isolated from each other by an 1 atergranular phase of Insulat $1 \mathrm{ng} B 1_{2} \mathrm{O}_{3}$. The technical importance of these devices is that they may hove grater power handling capabilities for voltage surge protection than Zener diodes. However, iftele is known about the nature of the intergtanular phase which is property controlling. The research to date has been two-fold: (1) an Investigation of the ffects of systenatic chemical substitutions within the boundary phase on electrical ceramic properties, (2) the fabrication of simple bi-crystal devices for dielectrite dispersion weasurements and cole-cole analysis. A better understanding of the role of intergranular Impedance layers on electrical properties of ceramic devices should develop from thts investigation.

Dielectrlcs for energy storage require high dielectric constants and electric strengths. Investigations are underway by which reliable dense fine grain dielectrics way be fabricated fron high dielectric constant ferroelectric materfals, The deleterious effect of processing contaminants (e.g. $\mathrm{S}_{2} \mathrm{O}_{2}$, $\mathrm{Al}_{2} \mathrm{O}_{3}$ ) on h1gh power factors and low resistivities have been characterized, and verified by purposeful chemical additions. The effect of anion vacancles on long tern electrocheatcal degradation of ingulation resiatance has been investigated further, and a method of predicting reliability from current voltage measurements has been extended to include proton and hydroxyl charge transport. The results on rellability assurance have been extremely successful, and Industry today is using this technique for testing dielectric couponents whth w1ll be ued under continuous electrification. Indeed, we have a test named after us!

Results Expected, FY 77: He plan to continue our work on crystal growth, synthesis, ceramic preparation and dielectric evaluation of $\mathrm{Pb}_{5}\left(\mathrm{Ge}_{3} \mathrm{SL}_{3}\right)_{31}$, $\mathrm{BI}_{2} \mathrm{WO}_{6}$ and assoctated derivative structures. The phase trangtion behavior of lead germanate wi11 be characterized as a function of loonorphous chenical substitutiong, particularly with $\mathrm{Ca}, \mathrm{St}$ and Ba. We are searching 
for a broad distributed "second-order" type phase transtition which would be suited for improved pyroelectric thermal sensors and electric generators. One aspect of our vork will be concerned with the recrystallization behaviar of glass-ceramic layered coatings, (sultable for solar energy collectors), In an applied electric fleld. This technique would pole the eryatals in a preferred alygnment as they grow In the glass. As far as we are aware, this approach has never been atcempted, and if successful, the single domain aligned polar crystals would maximize the pyroelectric effictency. The pyroelectric effect is a 24-hour phenomenon, day after day, and unlike the photoelectric effect, Independent of sunlfght. A pyroelectric generator would work continuously (provided time dependent changes occurred--naturally or man made) at any location and lattitude on earth or in spacel

Hydrothermal crystal growth of $\mathrm{Bi}_{2} \mathrm{WO}_{6}$ will be contintued in a larger $500 \mathrm{~m} 1$ pressure vessel coastructed out of $\mathrm{HY} 100$ streas corrosion resiatant steel, The use of baffles, extended growing times and higher pressures will be investigated. Cerantc specimens (fabricated by conventional sintering processes) will be poled and the plezoelectric properties determined. We plan to continue out interaction with the Coordinated Sclence Laboratory on sputtered $\mathrm{BI}_{2} \mathrm{HO}_{6}$ thin films. The evaluation of new plezolectric materials will be continued and crystal growth studies initiated for candidate onterlals like $\mathrm{Ba}_{2} \mathrm{TIS}_{2} \mathrm{O}_{6}$ and $\mathrm{PbTHO}_{3}$.

Dense diphasic dielectrics fabricated by the technique of liquid phase sintering In the system $\mathrm{BaT} 10_{3}-\mathrm{Pb}_{5} \mathrm{Ge}_{3} \mathrm{O}_{11}$ w11l be characterlzed further. of particular 1nterest is the energy storage capability at high electric flelds. Diffusion couples, wetting studies, and mixture resctivity will be deterwined by XRD, EPMA, $S$ aM and Curle-Welss analys1s. The effect of particle size distribution on wetting without ctystalline substitution wll be deterwined, and the high fleld properties measured. The concept and practice of electric ffeld spliting by merostructural englneering is to be developed further.

Results Expected, FY 78: We expect to continue out work on crystal growth of polat materials and develop the cepability of top-seeded flux pulling. The characterization technique of second harmonle generation (SHG) 1n acentric solids will be introduced for evaluation of new materlals guitable for energy conversion applications. The novel technique of Curle-telss analysis w11 be developed further for determining reaction kinetica in ferroelectric mixtures by comparison with thermal SHG data. Curle-Wetss analysis is several orders of magnitude more sensitive than XRD. The ferroelectric behavior of polycrystailine Harbo ${ }_{3}$ (which in single crystal form is antiferroelectric) wil be examined, and a thermodynamic analysis formulated to determine if anisotropic grain boundary thermal stress is suffickent to modify the properties of the polarizable deformable solid. The electric and dielectric nature of grain and phase boundaries in electrical ceramics will be lnvestigated further. We plan to use Auger spectronetry to determine depletion layer depths at interfaces 1n varistors and thermistors, and correlate th1s infornation vith calculated values from fopedance measurements. The purpose of this work is to obtain a more fundamental underatanding of the role of microstructure upon electrical properties and develop the concept of microstructural engineering for property optimization in energy related materlals. 
Relationship to other Federally Funded Projects: The crystal growth and characterization studies are related to other materials research prajects in this Laboratory. In addition, the determination of structure-property relations in single erystals, and texture effects in polycryataline systems are of Importance to the program in Materlals Engineering. Our flndings on new plezoelectric and ferroelectric solids are of practical significance to the acoustic delay 11ne project in the Coordinated science Laboratory and the acoustooptic--electrooptic effort on quantum electronics in Electrical Engineering. Hew pyroelectric materials ars of considerable 1nterest to members of the Ceramlc Englneering faculty concerned with Cerantcs for solar energy. Also, the melting points of highly polarizable $\mathrm{Pb}_{5} \mathrm{Ge}_{3} \mathrm{O}_{1}\left(750^{\circ} \mathrm{C}\right)$ and $\mathrm{BI}_{2} \mathrm{WO}_{6}\left(1080^{\circ} \mathrm{C}\right)$ are of practical importance to the program on 1iquid phase sintering of diphasic dielectric mixtures (funded by the National Sclence Foundation) in the Department of Ceranic Engineering. The theoretical and experinental studies on the effects of polycrystalifne nicrostructure on dielectric properties relate to other electrfcal-ceramic programs which are concerned with the role of interfactal 1mpedance layers on the propertles of semiconducting ferroelectric thermal senaors and current 1 imiters, and $\mathrm{ZnO} / \mathrm{B}_{2} \mathrm{O}_{3}$ voltage overload protection devices which are now being considered for application in high power transmission equipuent.

Publications: (Calendar Year 1975)

None

M.S. Theseg: (Calendar Year 1975)

None

2h.D. Thegea: (Calendar Year 1975)

None 
Nuclear Magmet 1c Resonance Studies of Metals and Polymers

Principal Invest1getor: Theodore J, Rowtand, Ph,D, Profeseor of Physical Metallurgy

Supporting Agency: U. S. Energy Research and Developent Administration

Senior Staff: Theodore J, Rowland, Professor

Jtolor Staff: Lance C. Labun, Research Assistant

Patrick Lenahan, Research Agsistant

Robert S. Shalvoy, Research Assigtant

Object: Th1s program has applied nuclear nagnetic resonance techniques to the study of netals and polymers. The central theme is the investigation of local electric and nagnetic field configurations within metalis crystal 1attices. These fielda reflect the effect of stomic al ze and valence on alloy propertieg and the manner in shich local electron densitles respond to the introduction of impurities Into the crystal 1attice. The capabilities of MMR for the meagurenent of atomic mobility are applied to the detexmination of the diffugton coefficients and motional correlation tires in solids.

Since metallic systens remain the predominant materlals for mechanlcal and structural uee, thelr Investigation will continue to be stressed. Future energy conversion devices w111 operate at h1gh temperature for thermodynanic reasons and in complex environments which will introduce foreign, usually deleterioue materials. Solute interactions and atomic diffusion will be of cructal importance and nuclear magnetic resonance is a powerful technique for thetr investigation.

Diffusionless phafe transfornationa influence the phonon opectrum of certsin alloys at temperatures far higher than that at which the low temperature phase is stable. These gtructural fluctuations degerve intenge ecruting because they undoubtedly play a role in high temperature atomic migration. They have been identified in fust those alloys (T1, Zr, Hf-V, Ta, Cr, Mo, W) which appear promiging on other grounds for advanced degign applications. Present experimental data has suggeated the nature of these heterophase fluctuations but the local symetry is atill to be determined and, most importsntly, the lifet ime of the fluctuations ta unknown. Thes quantitles are critical for the determination of the full utility of this unusual behevior. Since nuclear resonance techniques ar ideally ousted for thelr study, thalr exploration ta a gignificant goal of the program.

Recent and ongoing Inveatigations Include the Investigation of interstitial trangition metal solutes and oxygen and nitrogen 1n vanadiun. Since the vanadium nuclear magnetic resonance io particularly sensitive to these interstitial Impurities, it was dearrable to understand their effect 
thoroughly before proceeding with the analysis of other alloys. Data for the solutes $\mathrm{TI}, \mathrm{Cr}, \mathrm{Mn}, \mathrm{Fe}, \mathrm{Co}, \mathrm{H} 1, \mathrm{Mb}, \mathrm{Mo}, \mathrm{Ta}, \mathrm{W}$, and $\mathrm{Pt}$ in $\mathrm{V}$ indicate

- that solute screening is of short range and loss slgnificant than the size of the solute as measured by its effect on the $V$ lattice parameter.

Studies of Group $a$ transition metals in copper and of concentrated alloys of Group B elements with copper have greatly extended our knowledge of metallic solld solutions. Related systens atudied have lncluded aluminum, aluminum alloys, the Inter netalilc compounds $\mathrm{V}_{3} \mathrm{SI}$ and $\mathrm{V}_{3} \mathrm{Ga}$, and the age hardening of Cu-2 wt: Be s1loys. The tnterpretation of the latter experiments relled on an earlier investigation of Cu-4.8 at. $\mathrm{Xg}$ alloys. The studies of atonic motion have been extended, recently, to tnclude the diffusion of $\mathrm{H} \mathrm{In} \mathrm{Nb}$, the effects of hydrogen bonding in liquid amines, and molecular motion in three-dimensional organtc networks of crosslinked polybutadiene. The central theme of the research remains, however, the electronfc structure of metals and their alloyg and tts effect on atomic motion and structural propert1es.

Resu3ts, FY 76:

Most Significant Accomplishments: The conpletion of the study of age hardening in copper-berylilum alloya revealed general coherent precipitation of the compound CuBe on a scale so fine as to have escaped detection by electron wicroscopy.

Other Results: The experimental phase of an investigation of the relationshlp between nuclear relaxation and the average network cha1n length in polymers was completed. The significance of the results lies In the characterization of the restricted cha1n motion and the application to curfing phenomena in certain thernosetting materials.

An intial sertes of neasurementa of proton relaxation in $\mathrm{Hb}-2$ at $z$ a alloys from $-100^{\circ} \mathrm{C}$ to $45^{\circ} \mathrm{C}$ has been completed. These results are a contribution to the group study of hydrogen in metals at lilinols and a preparation for our projected investigstion of phase stability in transition netal alloys .

Resulcs Expected, FY 77: The Investigation of diffusion of hydrogen in wb and in other transition wetal slloys will continue in cooperation with H. BImbaun and callaborators. The effect of other interstitial solutes on trapping of hydrogen will be deternined.

Heterophase fluctuations in w phase alloys like $\mathrm{Zr}-\mathrm{Nb}$ and $\mathrm{T} 1-\mathrm{V}$ will be pursued with the spectflc objectives dependent on the results galned fron present initiatory experiments. Our experlence with thege nucle1 Indicates that such experiments will detect changes in the local atonic symetry accomanying the phase fluctuations, and also reveal the average time interval during which the metastable phase exists. In the courae of these experiments the kn1ght shift and ordinary (static) quadrupole effects w11l be monitored as a function of texperature. 
The structural transformations ve propose to Investigate utilfze several of the well-known interactions between the lattice electrons and the nuclei. Evidence frow neutron scattering and $X$-ray diffraction experiments indicate the presence of quasi-static thermal excitations existing in the alloys which exhibit the w-phase transformations. The fluctuations, even at temperatures many hundreds of degrees higher than the athermal w-phase transformation, appear to exist for times long telative to the lattice vibrationel pertod. Since the transttion involves a diaplacement of lattice planes in the orlginal bec structute, there will exist charge density shifts stabllizing the new structure. These fluctuations are rapid, and large compared to ordinary atonic lattice vibration amplitudes. Their practical significance lies in thetr effect upon the mechanical and annealing properties of these alloys at elevated temperatures.

Work Intiated in the erea of crosslinked polymers will have been completed, and 1 ts future 1o at present uncertain. The results can be expressed briefly in tarns of the extent to which chain notion is inhibited by crossifnking. Relaxation measurenents of the type conducted essentfally siagle out speciftc frequency components of moleculat motion. This study, if continued, vill be specifically afmed at determining the spectral distribution of the motions in crosslinked polybutadiene and in certain block copolymers of polybutadiene. Motion is highly correlated in these waterlals and there is no sfngle statistically independent wot lonal time or even distribution of such tines whlch can characterize the molecular motion. Further productive work in th1s area may require more support than can presencly be spared from other aspects of this program, and the work will be discontinued if equipment capable of relaxation measurements over a wide frequency range cannot be obtained. It was planned to devote no wore than one third of the total program effort to this pursuft in any case.

Results Expected, FY 78: The focus vill continue to be the understanding of the mechanisn by which elements propagate the effects of their valence and size difference through the netallic lattlce. Thts has been the central theme of this work for an extended perlod, but now $1 \mathrm{t}$ appears that the emphasis mus shift to elevated temperature studies of transition metals and their alloys, and concomitantly to the effect of interatitial additions to these systems. There are many simllarities among related transition metal systems, reminiscent of vell-known valence effecta in the Group $A$ metals; efforts to maximize the significance of our experimencs w11 exploit these relationsh1ps. The overwhelming proportion of our past work kas 1nvolved the study of charge denatty in alloys via nuclearelectron Interactiong. Th1s 18 the dominant theme about which the progran coheres. The ramifications of such information are widespread, and basic to the evolution of alloys.

We have for many years followed vith interest and appreciation the work of P. Beck. Our close contact and continuing digcussions of h1g work on the conditions for the existence of localized nagnetic momenta 1n alloys of non-magnetic vith megnetlc elements have suggested nuclesr resonance experiments which would complement his studies. The geasuremants of 
Beck's group are macroscopic in nature, consisting prinar1ly of observat lons of susceptibility and mognetization, by both ac and de techniques. The Interpretation usually rests ufon the exlstence of certaln atonic configurations. The latter, when treated self-consistently, lead to the observed property. There is no serlous doubt of the validity of Beck's analyses, yet frequently tt would be satisfying if experinents which are esgentially atomistic in nature were conducted in a collaborative fashion. We believe such work could lead to frultful new insights into the nature of the interactions involved, and in view of the role of magnetism and magnetic properties in many aspects of energy conversion we concelve this work as lying within the scope of the present progran.

Relationship to Othex Federally Funded Projects: The strength of the research program of the College of Englneering at the University of Illinols in the areas of diffusion, defect atructure, phase transformations, tadiation damage and electron1c structure provides an essential environment for the present and proposed work. The research is influenced by and cooperates with the overall thrust on hydrogen in metals of $\mathrm{H}$. Birnbaum and collaborators, with studies of interstitial solid solutiona of $C$. Altgtetter and C. Wert, with P. Beck's Invedtigation of the magnetic propertieg of transtition metal alloys, and the NMR research of $\mathrm{C}$. slichter. The research on amorphous polymers has benefited greatly through close association with the theoretical work of $R$. Gaylord and with the high pressure polymer research of J. Jonas.

The objectives of the program are closely related to those of groups at Argonne National Laboratory and the Ames Laboratory with whon effective contact is thaintsined.

\section{Publications: (Calendar Yesr 1975)}

T. J. Rowland

A 14 N Nuclear Relaxation Study of Hydrogen Bonding in Diethylamine-Alcohol Solutions

J. Chem. Phys. 63, 608-612 (1975)

T. J. Rowland and A. C. Yen

A Study of Precipitation Using Nuclear Magnet1c Resonance: Cu-2 wt 7 Be Acta Metall. (10 press)

M,S. Theges: (Calendar Year, 1975)

None

Ph.D. Theses: (Calendar Year 1975)

None 
ED-02-02-00-0 SOLID STATE PHYSICS STMMARY

The solld state physics research can be divided into the two broad areas of (1) research on the electronic structure of materials of importance for the understanding and control of the flow, conversion and storage of energy and (2) research on the aspects of crystal structure and its defects which are basic for an understanding of mechanical and thermal properties. Application of high pressure to solids, ranging to hundreds of kilobars, decreases the atomic spaclng with a resultant perturbation of the electronic structure. Professor H, Drickamer has exploited this techn1que to quantitatively characterize electronic transfer processes in alkali halldes, demonstrate that protein denaturation occurs in steps that can be reverstble, make a critical test of bulliken's theory of charge transfer complexes, discover hydrocarbon dimers and tetramers of novel structure and demonstrate the transition from photochromism to plezochtontsm with pressure. The observations on protein denaturation will be quantified during the next year and the study of energy transfer in phosphors extended in conjunction with research on organic photochemlstry and photoconductivity in zine sulfide and silicon.

The tagnet1c properties of transition elements in non-magnetic host metals have been investigated by Prafessor $C$. Slichter who has determined the position of the energy levels, the crystal splittings of the $3 d$ electrons, and the number of $d$ electrons of iron in copper through nuclear magnetic resonance measurements. These measurements are being extended to $\mathrm{Co}_{\mathrm{g}} \mathrm{Cr}$, and Mn in copper where the data have proven the importance of crystal 
splitting for the magnetic properties of tron group atoms in metals. The resonance technique will be applied to the electronic atructure of layer compounds Like TaSe, with a test of Professor W. Makillan's theory of Inconmensurate charge density waves. Another area of application of the resonance technique that will be continued is the electronlc structure of comercial hydrocarbon catalysts of platinum on silica and alumina substrates,

A new project of Professor J, Dow will investigate theoretically the electronic processes that determine the sbooption and emission of electromagnetic radiation by real solids. Problems to be Investigated are two photon absorption, fleld ionization of excitons, the effect of internal fields due to impurities and phonons in limiting transparency of the optics of laser systems. Th1s research is pertinent to photovoltalc and photothermal energy conversion, thermoelectric effects, and the use of synchrotron radiation for the study of surfaces, impuxities and defects.

A second new experimental progran, carried out by Professor D. Ginsberg, in cooperation with the group studying gases in metals is the effect of hydrogen on the properties of superconductors. The focus of tomediate interest is the mechantom by which hydrogen can increase the transition temperature of niobium, the increase of energy losses in nioblum superconducting accelerators, and the production by hydrogen of superconductivity in metals like platinum. The results are expected, however, to contribute broadly to the understanding of the effect of hydrogen on the properties of the refractory metals. 
The effect of crystalline defeets on the mechanical and thermal properties of solids has been an area of traditional strength at Illinois with major contributions fron Professors A. Granato, D. Lazarus, J. Koehler and R. Simmons,

The ultrasonic techniques of Frofessor A. Granato are applied to the study of interstitials tn metals, dislocations and the strength of metals, and nop-ifnear elastic behavior. These experiments have tecently extended : the theory of the effect of $\$$ slocations on internal friction and provided a synthesis of theories of mechanical behavior of crystals. In the Iumediate future, experiments will concentrate on the structure of interstictals in metals and hydrogen in palladium, on the developuent of the theoty of dislocation fateraction with obstacles and a test of the temperature dependence of the elaste constants of lonlc crystals and metallic alloys.

The diffusion studies of Professor D. Lazarus are concentrated on the diffusion nechantsms that exfot in the anomalous bec transition metals, like titaniun, and the superionlc conductors, like $\mathrm{RbAg}_{4} \mathrm{I}_{5}$. Both classes of material show abnormal and extraordinartly large diffugion coefficients. A small regative activation volune has been found in $\mathrm{RbAg}_{4} \mathrm{I}_{5}$ so that interstitial silver atoms are probably the mobite elements. Future research will contfnue the investigation of superionfe conductivity mechanisms which are of ilaportance for the application of these materials in energy storage devices, complete the 1sotope diffusion measurenents on titanium, and, because of $1 \mathrm{ts}$ technological importance, test the feasibilfcy of a bastc investigation of wear and attritfon of solid surfaces. 
Professor J. Koehler's experiments on radiation damage and 1 ts annealing are now turning to the hexagonal and body centered cubic metals where litcle information 1s avallable. At 1ssue are the properties of point defects, defect clusters, volds and the mechanisns of the1r formation and removal. It has recently been ahown by Koehler that there are two classes of bec metals with respect to the annealing of radiation Induced defects. One class, of which Iron and nioblum are examples, shows a relatively high temperature Stage I annealing near $80 \mathrm{~K}$; the other class shows low tenperature Stage I annealing neat $25 \mathrm{~K}$. Presumably the interstitial atructures, interstitial trapping, and vold formation are different for the two classes. Electron 1rradiation experiments are planned on the hexagonal metals $\mathrm{Mg}$ and $\mathrm{Cd}$ and the bcc metals $\mathrm{V}$ and $\mathrm{Cr}$. Inhibition of void formation through interstitial trapping by small core Impurities will also be tested.

A remarkable result of Professor R. Simmons' measurements of the formation energy of thermal vacancies in bcc ${ }^{3}$ He is that thetual notion occurs by quantum mechanical cunneling and that the defects have a nonlocalized structure with the propertles of vacancy waves. This achievement is a major advance in our understanding of defect diffusion and the structure of quantum solfds. The examination of thermal vacancies in ${ }^{3}$ He- ${ }^{4}$ He crystals is planned to determine the effect of isotoplc mass and different statistics. Since tunneling has been verifled as the rigration mechanism for vacancies in bee ${ }^{3} H$, the studies will be expanded to include hop 3 He. Consideration 1s being given to the application of the sophisticated x-ray scattering technlques to charge density waves in layered compounds. 
The superlattice period is short, diffuse scatterlng is large, and the probler is a difficult one.

The progran of Professor A, Anderson which will be Inttiated during the cuting year will use low temperature techniques to Investigate the relationshfp between structural defects, interfaces and themal energy transfer. Anderson has shown that themal transport in glasses, ceramics and polymers is entirely by phonons (1.e., that the phonon concept is applicable to anorphous materials), that the extra spectfic heat of anorphous materfals is due to localized excitations and that phonon scattering at the interface between amorphous materials is specular. H1s specific heat data on bydrogen in niobium has been used by Birnbaum and Flyn to verify their elegant theory of tunneling of intersticial hydrogen in nioblum.

The plansed research 1ncludes an 1nvestigation of the influence of grain boundaries on thermal conductivity where present theory and experi- . ment differ by a factor of $10^{4}$, an investigation of the technologicaliy important problem of heat transfer from solids to liquid helium and hydrogen, studies of the excitation spectrun of conducting ions in the supertonic beta alumina and the development of apparatus for thermal expansion measurements with a resolution of $10^{-3} \&$, a factor of 100 better than presently svailable. The dilatameter will be useful for studies of interstitial hydrogen in refractory metals, the excitation spectrum of tons in superionics, and the locallzed excitations of disordered materials. 
ED-02-02-02-0 Exper imental Heseatch

Use of Very High Pregsure to Investigate the Structure of Matter

Princlpal Investigator: Harry G, Drickaner, Ph,D.

Profegsor of Chantcal Engineering and

Physteal Chentstry

Lember, Center for Advanced Study

Supporting Agency: U. S. Energy Regenrch and Developnent Adainistration

Sentor staff: Harry G. Drickener, Profeesor

K1mihiko Hara, Research Associate (Beg1n 4/1/76)

Junlor Staff: Kevin W. Bieg, Research Assigtant and GE Pellow

Eric N. Hockert, Reasarch Asolotant and AMOCO Fellow

John W. Hook III, Research Assistant

Gary L. House, Research Assistant and Union Carbide Fellow

Dean J. Mitchell, Research Assistant

Willam D. Drotning, Research Aesistant (Terw 10/15/75)

Martin I. Finston, Research Assistont

David I. Klick, Research Alols tant

Cratg E. Tyner, NSF Fellow

object: The fundamental thesis of our research progran is that very high pressure 1s a most powerful, indeed an essential, varlable for understanding electroble structure and electronte behavior in condenged systems. The central feature of this research has been the geloction of those classes of materisls and types of measurenents which yield the nost 1mportant information and thost useful generalizations about electronic phenomena. Incldental to this process has been the developwent of techniques for measuring various features of optical absorption and entssion spectra and of Mogbauser resonapce spectra as well as electrical registance to relatively bigh pressures, in some cases to several hundred kilobars.

The basic effect of pressure is to decrease interatomfc distance and thus to increase the overlap between adjacent electronlc orbitals. As a consequence, the energy of any one electronic state, in general, changes with respect to that of other stateg. The information which can be extracted frow theBe energy ahtfta can conventently be classifled in three catagories. (A) It is possible to characterize electronic energy states and excitations. (B) It 1s possible to perform critical tests of theorles and hypotheses concerning electronic processes. (C) In a wide varlety of naterials the telative shift in energy ia suffictent to establish a new ground state for the system (or to nodify 1 ts characteristico greatly by configuration interaction). These nes ground states may have new and interesting physical and chemical propertes. Studies of pressure-1nduced electronic transitions have contributed considerably to our understanding of electrontc phenomena. 
We list here a few Itens in each category wh1ch sample some past contributions in each of these areas. Below ve discuss current and profected work which falls largely under categorles (A) and (B). A reading of there sections is intended to convey the flavor and philosophy of the work without beling an exhaustive 1iat.

\section{A. Characterization of Electronic States}

1. Shifts of the absorption edge in Insulators and semiconductors 1llustrate the expected reduction in energy gap in simple materials, as well as detalled information about the more complex structure of the conduction bands in silicon, germanium and related III-V, II-VI, and I-VII compounds.

2. Changes in the location and shape of optical absorption and fluoreacence peaks with gressure have provided essential information about Iocalized transitions. It has been possible to evaluate in detall a varlety of characteristic parameters for configuration coordinate diagrams, as well es to Improve our understanding of Jahn-Teller effects and photostimulated luntiescerce.

3. Hobsauet resonance studies of the change 1a 1somar ahift and quadrupole splitting with pressure have added considerably to our understanding of Ionic and covslent bonding in ferrous and ferrfe compounds, espectally organometallic materials. Measurements on bcc, $f c c$, and hcp transition metals have illustrated differences in the band structure of the bac and close packed metals.

4. Móssbauer 'resonance studies of the ragoetic field as a function of pressure have been helpful in understanding magnetism in iron, cobalt, and nickel, In palladium-iron and palladiur-cobalt alloys, In a series of orchoferrites, and In $\mathrm{Fe}_{3} \mathrm{O}_{4}$.

B. Critical Tests of Theor1es

1. Some of the earliest and most bastc tests of Ilgand fleld theory as applied to transition metal complexes were obtained fron bigh preasture optical studies. The measured changes in 11gand fleld strangth and Interelectrontc repulsion (Racah) parameters clearly illustrate the possibilities and ilmitations of the theory.

2. Our measurements of shifts of absorption edges conblned with electrical reststance work constituted the first critfcal test of the approach to the setallic state as described by simile bard theory.

3. Our studies of calciun and strontium listed under.(C)-1 below provided a direct test of band structure calculatlons on alkallne earth and related elements.

4. Our studies on the shifts of electron donor-acceptot tranaitfons w1th pressure formed a critical test of iulliken's theory of charge transfer complexes. 


\section{Electronic Transitions}

1. Reolstance anomalles associated with electronic transitiong have been observed in alkali, rare earth, and alkaline earth metals. In addition to the $6 s+5 d$ traneftion observed by Bridgnan in cestum at 40 kilobars, there is a second realstance anomaly at 100 to $130 \mathrm{kIlobarg}$, ponalbly involving the $4 \mathrm{f}$ band. The $(n+1) s+$ ad transition has been obaerved in rubidium and apparently in potassium. A number of resistance anonalies are observed in rare earth metals, probably assoctated with $4 f+5 d$ tranoitions. Calctum, atrontium and ytterbiun exhibit metal to semiconductor transitions assoctated with a simplifylng of the shape of the Fernd aurface with reapect to the Brilloutn zone boundary.

2. Insulator-netal transitions with a variety of characteristics have been observed. Transitious with no discontinuities in structure or resistance occur in iodine, In several crystals involving large organic moleculos like pertacene, and in the thallous halides. Transitions lnvolving diecontinultiea in restatance and changeg in atructure occur in silicon, germanfum, and many III-V and II-VI compounds.

3. An extengive seties of studies Involving both Mössbauer resonance and optical absorption has revealed a rich varlety of electronic transitions In iron compounds. These include both (reversible) high spin to low spin and low spln to high eptn trangttions which depend on the nature of the 11 gand and $1 \mathrm{ts}$ binding to the tron. The revergible reduction of Fe(III) to $\mathrm{Fe}$ (II) has been observed in a wide variety of coupounds. Optical gtudies have also denonstrated the reversible reduction of Cu(II) to $\mathrm{Cu}(\mathrm{I})$ as well as changes of oxtdatfon state of Sb(III) and Sb(V) in mixed valence compounds. Intengive collaboration with C. P. Slichter, Profesgor of Physics, has resulted in considerable progress in explainfing these and other electronic transitions.

4. A large decreage in $\pi+\pi^{*}$ excitation energy with preasure has been observed in many organic molecules. In sone cases this is sufficient to permit thermal occupation of the $x^{*}$ state at high pressure and consequent chemical reactivity of a new sort. Similarly the decrease in donor-acceptor excltation energy with presstre in a large varlety of charge transfer complexes results in thernal occupation of the excited state and a sertes of new reactions. A detalled study of the behavior of iodine-pyrene and lodine-perylene complexes has demonstrated the existence of hydrocarbon dimers and tetraners with atructures entirely unlike any previously reported.

S. In photochromic conpounda an optically excited electron decays to a new thetastable ground atate which involvea a change of chemical conformation. High pressure studies on bianthrones, splropyrano and antls denongtrate that preseure can change the relatfve energfes of the stable and netastable state sufficlently to pernit theral occupation of the metastable state, 1.e., plezochromisn replaces photochronisn at high preglure. 
Results, FY 76:

Mogt S1mificant Accomplishment8: (1) We have perfected a high preasure Iumfnescence apparatus for pressures to $150 \mathrm{ktlobars}$ and have made a detailed study of lmpurity lons especially $\mathrm{Tl}^{+}$, $\mathrm{In}^{+}$, and $\mathrm{Ga}^{+}$in alka11 halides. Fron peak shifts and shape changes with pressure we have evaluated the configuration coordfnate parameters (displacenent and force constants of the electron ground and excited states). We have demonatrated that the relative Intensfity of the Jahn-Teller split component of the spectrum 1s distinctly pressure dependent and that therefore these components couple significantly to the totally gymetric vibrational coordinate. We have measured the rates of the electron transfer processes $\mathrm{In}^{+}+\mathrm{V}+\mathrm{h} v+\mathrm{In}^{+}$ $+F$ and $\mathrm{In}^{++}+\mathrm{F}+\mathrm{hv}^{\prime}+\mathrm{In}^{+}+\mathrm{V}$ (where $\mathrm{V}$ - vacancy and $\mathrm{F}-$ color center) as a function of pressure and have demonstrated that the effect of pressure can be predicred quantitatively from measured averlap 1ntegrals. These studies constitute the most detailed and quantitative characterization ever done on these processes in the alkal1 halldes and w1ll be presanted in a sat of four papers in the June 15 Physical Rev1ew.

(2) In collaboration with G. Weber, Professor of Blochentstry and Blophysics, we have developed a technique for studying protein dénaturation under pressure by means of fluorescence. Protein is the major source of energy for $21 v i n g$ creatures, and the denaturation process 18 poorly undergtood. We have been able to demonstrate that the changes of conformation take place In steps, e.g., the tryptophang quench between 3 and 6 kilobarg while the positive charges become avallable for complexing in the range 6 to 12 kilobars. We have shown that only a fraction of the tatal possible sites actually change confornation 1n the denaturation process, that the volume change assoclated with each step is less than $1 \%$ of the wolar voluwe, and that the process can be reveratble. These studies are in thelr early stages, and only one proteln has been studied quantitatively, but the technique shows great promise.

Other Results: (1) Our 1nitial work concerning pressure effects on energy transfer 1n phosphors 1ndicates that high pressure studieg are providing a quantitative test of Forster-Dexter theory. The importance of this work and our future plans are discussed below. (See FY 77)

(2) We have developed a technfque to measuxe the effect of pressure on phosphor decay rates as fast as 0.1 ntcrosecond. We plan to apply this technique to a wide vartety of phosphors.

(3) We have shown that there is a very large effect of pressure on the quantum efficlency of phosphors. For localized excitations in oxygen dominated phosphors this can be explained in terms of changes in the configuration coordinate parameters wich can be celculated from peak shifts. Thus one can predict phosphor effictency from peak shift data. For doped ZnS and ZnSe phosphors the efficiency depends on tovement of trapping levels which we can deternine with our new high pressure thermolminescence apparatus. These phosphora have great importance in practical devices such as fluorescent $11 \mathrm{ght} 1 \mathrm{ng}$ and osctiloscope screens. 
(4) We have initiated a rather extensive progran of high pressure organic photochemistry. A constderable fraction of this program is a joint effort with Gary Schuster, a very bright young Assistant Frofegsor of Organic Chemistry. It has been denonstrated that excited triplet states fincrease in energy wh pressure relative to exclted singlet states; occupled nonbonding levelo 1ncrease in energy relative to bonding levels. Many organic photochemical reactions proceed only wen one of these states $1 \mathrm{~s}$ preferentislly occupied. The effect of pressure on the reaction yields and rates provldes a clear-cut test of mechanisn.

Many photocheulcal reactions are of great practical importance but are poorly understood--an exanple is photosynthesis, a second is the operation of the eye, and a third 1s photopolynerization. He belleve our experinents may contribute gigniftcantly to the necessary understanding.

Results Expected, FY 77: Our plang for 1977 can be divided into two categories: extension and completion of current work and the initiacion of new projects.

(A) 1. We plan to extend and to quantify our studies of protein denaturation. In particular, we hope to classify more sccurately the types of sites which denature in different pregsure ranges in different proteins and the fraction of attes of each kind which are involved in the process.

2. We plan to extend greatly our study of energy trangfer in phosphors-to organtc cryatels, to plastic media, and to liquid solutions. Energy trangfer is an essential step in nany practical processes fron fluorescent lighting to photosynthesis, and its complete understanding is essential. Our measurements of decay rates are basic to this underatanding.

3. We plan to complete our studtes of quantum effictency of inorganic phosphors, to show the posstbilities of present theory, and to develop tefinewents of the theory. Again, a study of decay rates 18 essentfal as well as high pressure therwoluninescence weasurements.

4. We plan to extend greatly our work on organic photochenistry. Our initlal work shows very large effects on photochromlc processes, on reaction rates of aryl ketones, and on a varlety of other reactlons, as well as on fluorescent and phosphorescent yieldg. This ares appears to be one of the mast prowising for future developent.

(B) 1. We have tested the feadbllity of high pressure photoconducting and photovoltalc effects. We have designed an apparatus and plen to intelate studies on CdS and selentum with a variety of dopants. We will ultimately extend our work to sil1con, to $\mathrm{ZnS}$, and to organic photoconductors. A better understanding of photoconductivity is very relevant to aspects of the golar energy problem.

2. We have des1gned an apparatus for neasuring the depolar 1zation of molecules by pressure. It should be particularly effective for studying mactomolecules in solution. Depolarization of light is a very effective way of character1zing change of conformation of a large molecule. It 1s also an easential feature of wany photochentcal processes. 
Results Expected, FY 78: Our plans for 1978 envision an extenston' of our pregent work and expansion into new areas where we can use presenre to increase our understanding of electronlc processes in condensed systems. We beli.eve that various aspects of organic and inorgantc photochenistry and photoconductivity have so many facets and such wide applicability in improving energy conservation that we will be concerned with these processes for a conalderable period to come.

As outilined in Object, our theme is the essential nature of pressure for taderstanding electronic behavior. He continue to develop various aspects of this these to fill out the three categories of phenomens we diacussed in that section. In a real sense this is a continuing progxam. We try to explott given techniques and study given clasees of materials long enough to establish generalizacions which form the basie for new theory, or the critical teat of existing theory, whout, bowever, becoming a factory to crank out dats. The program is an evolving one as new techniques are Introduced to study new aspects of sclence or new materials and as we discover new phenomena around which to reorlent our research.

Relattonshlp to Other Federally Funded Prodects: There is really no other laboratory in the world which duplicates any significant fraction of our studies on preasure and eiectronfc structure. McWhan and Jayaraman at Bell Labs have made significant contributions in the area of inaulator-netal transitions, Offen at Santa Barbara and Nicol at UCLA have performed a number of luportant studies of organic phosphora. Oux research has been used extensively by theoretictans in phyaics, chealstry, and geophysics for testing the analyses which they have developed.

Over the years we have collabotated wh people in a varlety of fields, and these collaborative efforts appear to be on the 1ncrease. The most valuable has been the continuing interaction with $C$. P. Slichter of the Physlce Department whlch has led to a real understanding of the nature of a vartety of electronic transitions, Earlier cooperation with H. Fravenfelder and P. Debrunner of the Physica Department was very valuable in developing high presaure Móssbauer resonance cechn1ques. Gregorto Weber, Professor of Biochemistry and Blophysics, IB the noving spirit behind our very interesting and fruftul studies of protela denaturation. G. Schuster, Asolstant Professor of Organic Chemistry, is working intensively with us on various aspects of high pressure photochemistry, and hls suggestions and assistance with syntheses have been extrenely valusble. We interact almost daily with J. Jonas. Professor of Physical and Analytical Chentetry. We plan some direct collaborative work, but the relacively subtle contrlbutlons spanned by this continuous interaction far exceed the lints of any particular project.

Our expertise contributes in an Indirect way to a continuing Iateraction with the Catalyst Group at the Corporate Research Labs, of Exxon Research and Engineering. 
Publications: (Calendar Year 1975)

H. G. Drickamer

The Effect of Pressure on the Electronic States of Organic Solids

Proceedinge of International Conference on organic Synethesis, Belgitm, 1974.

Pure and Applied Chem. $43,379-399$ (1975)

B. G. Dr1ckaner

Exploratory Regearch at High Pressure

Materials Under Pressure, edited by T. Hirone (Maruzen Press Co., Tokyo, 1975), pp. $\overline{1-35}$

H. G. Drtckamer

H1gh Pressure Studieg of Electronic Structure in Solids

International Review of Sclence - Inorganic Chemistry, Vol. 10, Solid

State Chemigtry, edited by L. E. J. Roberts (Butterworths, London, 197S), pp. 1-33

D. G. Wilsen and H. G. Drickamer

High Presaure Studieg on Spiropyrans

J. Cheut. Phys, 63, 3649-3655 (1975)

W. D. DrotninB and H. G. Drickaner

High Pressure Optical Studlea of Doped Alkali Hallde日. I. Peak Shifts and

Peak Shape Changes

Phys. Rev. (1n press)

W, D. Drotning and H. G. Drickamer

High Pressure Optical Studies of Doped Alkall Halideg. II. Jahn Teller Effects

Phys , Rev. (In preas)

W. D. Drotning and H. G. Drickaner

H1gh Pressure Optical Studies of Doped Alkall Halldes. III. Rates of Electron Transfer Proce日aeg

Phys. Rev. (In press)

W. D. Drotaing and H,.G. Drickener

High Pressute Optical Studies of Doped Alkall Halides. IV. Mixed Crystals

Phys. Rev, (1n preas)

C. E. Tyner, W. D. Drotning, and H. G. Drickaner

Asymmetric Line Shapes of Locallzed Optlcal Excttations in Condenged Systens

J, Appl. Fhys. (açcepted)

M.S, Thesen: (Calendar Year 1975)

E. N. Hockert (H. G. Dricksner, Adviser)

The Effect of Preadure on the Electronle spectra of Some Salicylikineaniline May 1975 
G. L. Houge (H, G. Drickamer, Adviser)

Effects of High Preseure on the Luninescence of Z1nc Sulfide Phosphors May 1975

C. E. Tyner (H. G. Drickamer, Adviser)

Ef fects of Presuure on Oxygen Dominated Phosphors

Nay 1975

Ph.D. Theseg: (Calendar Year 1975)

W. D. Drotning (H. G. Deickamer, Adviser)

Lumfnescence of Impurfty-Act1vated Alkall Halldes Under High Pressure, Vols. I and II

October 1975

D. G. W1lson (H. G. Drickamer, Adviser)

Photochromic Studies of Splropyrans

May 1975 
Arharnonic Effect In Solids

Princlpal Invest1gator: Andrew V. Granato, Ph.D.

Frofessor of Physics

Supporting Agency: U. S. Energy Research and Development Adnfitotration

Sentor Staff: Andrew V. Granato, Professor

George G. Setser, Research Alelatant Professor

Junlor Staff: Terrell D. Berker, Regearch Asglatant

Randa11 D. Isaac, Renearch Agpiatant and Fellow

David L. Johnson, Research Asgintant

Dayld B. Poker, Reseerch Annstant and Fellow

Object: This research program uses the unique capabilittes of ultrasengltive wltrasonic techniqueg to investigate the structure of interstitlal atons in metalo (Including hydrogen in metals), to determine the role of dislocations in determinting the strength of metals, and measure non-1inear elastic propertjes which determine the thermal beharior of solids. The phenomens under inveetigation are all of central importance for the use of metal structuxes under extreme conditions of temperature, stress, and hostile environments which induce contaulnation by forelgn 1mpurities.

The attenuation and velocity of ultrasonic waves are neasured to obtain the mechanical response of perfect and nearly perfect crystals to applied forces. Especial use ts made of techniquea with a sensitivity of as much as one part in 107 for elatic constant changes. Speciflc objectives of this progran axe:

A. Interstitlels in Metals. We are studying the structure of point defects produced during radiation and annealing of metal. The structure is deduced from the anisotropy, relaxation and resonance type behavior of elastic constant changes produced by radiation danage. The information 1s basic to the understanding of how defects combine to produce larger agglowerates. The sene techniques are being used for the study of the structure of hydrogen in netalo.

B. Strength of Crystals. Amplitude dependent attenuation and velocicy changes are used to study unusual strength effects. Traditional theories of strength have been based upon rate theory assuming explicitly that the overcoming of obstacles la the rate-1initing atep. Imlifit asoumptions in this approach are that the dillocations do not overshoot the obstacles by reason of their Inertia and that the time taken to travel between obstacleg ia not rate-11miting. We are studying materiala for which these implicit asoumptions do not appear to be valld. 
C. . Non-IInear Elastic Effects. Many thermal properties of solids deperd upon deviatlons fron linear elastic behavior. We are measuring the temperature dependence of elastlc constants at low temperatures where the elastic constant changes can be used to determine third and fourth order elastic constants. This data is of use in determining useful eupficical interatomic potentials and equations of atate.

Results. FY 76:

Most Significant Accomplishments: (1) We have extended the theory of ampititude independent internal fitction by dislocations in two ways. The first way allows for long-range plining by dipolar polnt defects and gives an expression for the pluning force In terms of the concentration of defects. The second way perntts one to determine separately the changes in viscous drag and pinning drag forces. This second result was used to demonstrate that the changes observed by Simpson and Sosin during 1rtadtation (peaking effect) are in general due to both a plnning and drag, and not. solely due to a drag as had been prevtously supposed. The first result was used to denonstrate that pinning observed in neutron irradiated copper at $20 \mathrm{~K}$ is due to long range pinning from isolated interstitials, and not from short range pinning frotn lattice effects as had been assumed. The analysio demonstrates that such planing effects can be used to detect interstitials in concentractons as small as one part in $10^{7}$.

(2) We have begun a syathesis of theories of mectianical behavior of crystals which embraces wacroscopic (stress-stra1n, creep, recovery) and microscoplc measurewents (Internal friction). This involves classification of forces into viscous, Inertial, and restoring types, represented by wechanical models. The forces are further classified according to whether they are linear or non-lineat, short range or long range and small, moderate or laree. The synchesis relates many effects previously thought to be unrelated. A prelininary account of this work was given at the Gatinburg Conference on Rodiation Danage.

Other Results: The breakaway stress for dislocations in copper with small concentrations of aluminum has been found to have a maximu as a function of temperature. This is believed to be the result of inertial effects operating at temperatures as high as $50 \mathrm{~K}$. Such behavior is consistent with results found earlier for superconductors with1n the framework of our inertial model for the strength of crystals. Work is continuting on this project. The significance of the result is that it suggests that the traditional theories of strength may be not generally valid at low temper tures.

Results Expected, FY 77: (A) More systemat1c and detailed measurements of the effects of close pafrs and free interstitals separately in copper will be made. Also, measurements are in preparation for the resonance behsvior of "mixed dumbells" (Interstitials combined with an Impurity) in aluminum. Heasurements of elastic constant changes of Pd contafning 
hydrogen have been made and measurements with deutertum are in progress. A He ${ }^{3}$ refrigerator will be constructed for the detection of resonance mode effects at low temperstures.

(B) Breakaway stresser in lead in both the superconducting state and at tempetatures sbove the superconducting trangition temperature are in progress. Changes in attenuation at $10 \mathrm{MHz}$ are belog measured simultaneously wh th breakaway stresses at $10 \mathrm{kHz}$ in an effort to further test predictions of the Inertial model of dislocation interactions with obstacles.

(C) Measurements of elastic constant changes as a function of temperature In the low temperature $T^{4}$ region are being wade in LiF, beta brass and $\mathrm{R}_{\mathrm{OMnF}} \mathrm{M}_{3}$. These results will be anelyzed in terms of nearest and nextnearest nelghbor interactions to decermine gultable interatomic potentials For these substances, and to test a theory for the temperature dependence of elastic constants.

Results Expected, FY 78: We are expanding our efforts in the direction of more detalled studieg of the effects of dipolar point defects on the mechanical properties of solids. It is intended that the basic properties (symmetry, relaxation, and resonance modes) of such defects will first be studted. Thts should be followed by studies of the effects of such defects on the mobllity of dislocations.

Relacionship to Other Federally Funded Profects: We are coopersting with Jon Holder of MRL In studies of radiation damage in metals and the theory of deformation of Ice crystzls. A seuinar on properties of cryatals contalning dipolar point defects is in progregs conbinting students from our group with those of J. Holder and J. Koehlet. The work on hydroger Involves consultations and cooperation with many others in MRL participating in the hydrogen in metals thrust.

\section{Publications: (Calendar Year 1975)}

J, A, Garber and A, V. Granato

Fourth-0rder Elagtic Constants and the Temperature Dependence of Second-0rder Elastic Constants in Cubtc Materials

Phys. Rev. BlI, 3998-4007 (1975)

J. A. Garber and A. V. Granato

Theory of the Temperature Dependence of Second-Order Elastic Constants 1a

Cuble Materials

Fhys, Rev. B11, 3990 3997 (1975)

A. V. Granazo

Ultrasontc studies of Mechan1cal strength

Ultrasontcs Sympasiug Proceedingg. IEEE Cat. \$75 CHo 994-4SU (1975)

Also supported by NSF 
R. D, Isaac and R, B, Schwarz

A S1mple Peraistent Switch for Superconducting Solenotds

Rev. Sc1. Instrun. 46, 638 (2975)

K. D. Swartz, W. Bensch, and A. V. Granato

The Second-, Third-, and Fourth-0rder Elastlc Constants of Beta Brass

Phys. Rev. B12, 2125-2131 (1975)

R. 8. Schwarz and A, V, Granato

Measurement of the Force-Distance Profile for the Interaction Between a Dislocation and a Point Defect

Phys. Rev, Lett. 34, 1174-1177 (1975)

W. F. Weston and A. V. Granato

Cubic and Hexagonal Single-Crystal Elagtic Constants of a Cobalt-Nickel A1loy

Phys, Rev. B12, 5355-5362 (1975)

A. V. Granato

Dislocation - Defect Interactions and Mechanical Properties of Crystals

Proceedings of International Conference on Radiation Damage in Solids, Gatlinburg, 1975 (to be published)

Also supported by NSF

M.S. Theses: (Calendar Year 1975)

None

Ph.D. Theses: (Calendar Year 1975)

David Thomas Read (A. V. Granato, Adviser)

bias Stress Detection of Dislocation Resonance in Lead

May 1975 
Defect Propertles of Sol1dg

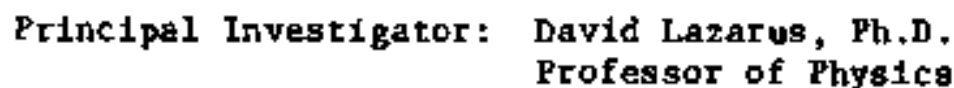

Supporting Agency: U. S, Energy Research and Developuent Adninistration

Sentor Staff: David Lezarug, Profesgor

John P. Bensel, Kegearch Ageoclate (Tern 12/31/75) '

Juntor Staff: Paul C. Allen, Rebearch Assistant

Genghmun Eng, Research Ass1stant

Mark S. Jackson, Research Asgistant

Ar thur E. Pontau, Research Ase1stant

Object: The chief aim of this project is to develop quantitative, atomistic models for describing defect and electronlc properties of classic, prototyp1c solids, In the hope that this will lead to the eventual development of new and useful naterfals. In a wide vartety of applications, solid materials are 11mited in their utility by plastic deformation, fracture, cotrosion, radiation enbrittlement, wear, fatigue, and a host of other alluents; 1toprovements to existing technological materials are found through alloy1ng, heat treatment, cold and hot work1ng, and other forms of metallurg1cal art. Common to 811 these processes is the basic elewent of mass transportdiffuston within solids. The Interflow of aton accounts for the limitations of solids as well as for the cures to these linitations. Out concern is with the atonistic aspects of the basic diffusion ptocess to isolate the electronic and atructural vartables which govern the rates at which both host and Impurity atoms can migrate. Prior work by our group and others has demonstrated that the bagic process is clearly governed by the existence of lattice defects--vacancles, Interstitials, and possibly nore complex mechan1smo-snd that a full knowledge of the diffuston process can only cone frow a detadled understanding of the underlying lattice defects.

Considerable work has been devoted prevlously to studles of diffusion in fcc metals and alkall halides, both cloae-packed structures, and a vacancy-type mechanism has been utamblguously 1dentified for these cases. Current work centers around two different bssic 1attices: the "anomalous" bcc transition metals, typified by $I 1$, and the "superionic" conductors, typified by AgI and $\mathrm{RbAg}_{4} \mathrm{I}_{5}$. Both these clasges of materials show extraordinarily large diffusion coeffictents, departures from Arrhen 1 us behavior in the1r temperature dependences, and large differences in qualitative behavior fron the "rules of thumb" for scaling diffusional phenomena and melting behavior in "normal" matertals such as fcc and hepstructured solids and nost bcc structures. Our current work centers on trylng to ascertaln whether a basic vacancy mechanism is operable in these "anomsloug" caleg, or whether new defect models wust be Invoked. 
100 .

Meagurements sre nade ualng precision radiotracer techniquea, supplenented, for fnsulators, by lonic conductfvity measurenents. Studtes of diffusion as a function of temperature permit determination of the basic enthalpy changes assoctated with the fundamental process; atudies as a function of strictly hydrostatic pressure (in a gas high pressure systen to ensure that additionsl defects are not introduced by plastlc deformation in the pressurization process) yleld values of the elewentary volune changes associated with Eotuation and motfon of defects. Studies of the asso dependence of diffusion (Isotope effect) peznt deduction of correlation effects fundamental to the bagic meagurement. It is only by a combination of these techniques that prectse information about the defocts responsible for diffusion can be elucidated.

Since impurity and host atoms usually diffuse at different rates in sollds, we are also concerned with learning about the electronic structure of defects and of impurity atom, and their interactions with the lattice electronic structure. Currently mesurenents are being made to search for possible anomalies in the electrical notge in $\mathrm{TaS}_{2}$ and $\mathrm{TaS}_{2}$, in which charge-denalty waves have been ldentifled by neutron diffraction, to see whether of not these perturbatlons give rise to large many-body fluctuations in the density of charge carriers which would limt the validfty of single charge carrier models. These atudies will also be extended to the supertonic conductors, where, possibly, very large charge carrier densities are tovolved.

Most of the experinental and theoretical work has centered about studies of diffusion in equilibriun systens, but gone effort has also been directed toward non-equilibrlum cases of diffusion under electrical (olectromigration) and thermsl gradients (thermomigration).

Results, FY 76:

Mogt S1gniflcant Accomplishmenta: Preliminary data have been obtained through high pressure studies of lonic conductivity in $\mathrm{RbA}_{4} \mathrm{I}_{5}$, which show that the charge transport process in the superionic regime is characterized by a very smail, negative activation volume, iuplying that the basic charge transport wechanisms ts, nost probsbly, by interstitlals in this phase. A pressure effect has also been noted on the second-order phase trangition in this phase; the temperature of this tranoftion apparently changes $v 1$ th pressure in a highly nonllaear uanter. The implicatione of this phenomenon are not yet understood.

Other Reeults: Work is nearing completion on atudied of the lsotope effect of two tin tracers co-diffusing in TI. This program has encountered major technical difficulties in the past year due to the necessity for developing some new, precfsion radiochemical techniques for geparating the tracers from the matr1x, but should be completed by the end of the year.

Work is progressing on studies of dtffusion of aliovalent impurtites in alkali halides to test out a new theoret lcal model for the effect of the tracer inpuritieg on the local vacancy concentratfon, extending studies completed earlier with divalent impurities. 
The noibe studies in dichalcogentdes have produced no usaful results to date because of mafor problems encountered in developing noise-free electrical contacts for these naterials to study "flicker"-type $1 / \mathrm{f}$ notse in the presence of dc currents. No excess "white" notse of the usual Johnson variety is found anywhere in the temperature range of interest, at elther the upper or lower phase transitions; in the absence of dc currents, the noise is that of a pure resietor of the same value, even very near the phase transitions.

Results Expected, FY 77: All the current programs should be completed or, if they prove intractable, abandoned. New prograns will be atarted to extend the conductivity measurements in the superionic silver ladides, including tracer measurements, if sultable low+temperature techniques can be developed. (E.g., In RbAg $\mathrm{I}_{5}$, diffusion of Ag 1s go raptd at room tetuperature ţhat an evaporated layer of silver cen be seen visually to disappear into the matrix wthin hours at roon cemperaturel clearly conventional tracer deposition-diffusion-sectioning techniques are totally unsultable for studying these matertals,) 0ther superionic materials w11 also be tnvest1gated, and studies will be undertaken to sae if there is excess notse assoctated wth the phase transitions (again, 1f low-notse electrical contacts can be developed). A new progran of Investigation of the effect of pressure on the behavior of mlctomagnet1c alloya is planned, In collaboration with Professor P. A. Beck.

Results Expected, FY 78: Programs initlated in FY 77 should be nearing completion, and, hopefully, will suggest new directiong. The current program may branch aut into totally nes directions: e.g. to studies of wear (tribology) phenomena, which have recelved remarkably little attention from a baslc research viewpoint, which are clearly of enormous technological lomartance, and where the a prlort parallels to diffusional phenomena (never studied in detall) are, at the least, intriguing.

Relationship to other Federally Funded Projects: None of our work directly duplicates research done elaewhere. Through ineetings, exchange of preprints, and correspondence, we walntaln close contact with other groups acotind the world working in related areas. Particularly close contact is malntained wh the groups at Argonne National Laboratory, the University of North Carolina, and the Centre d'Etudes Nuclealres at Saclay, France, where a large fraction of the beșt work on diffuaton 16 maintained. Within MRL, our work in superionic conductors is carried out in close collaboration whth the programs of Professors Plygare, KleIn, Metillan, and Salamon who are studying other aspects of these materials. Stmilarly, our studies of the dichalcogentdes complenents those of Profesgors Brown and Salation. We have also worked collaboratively with Profeasor holonyak in otudies of the effects of high pressure on charge transport and luninescence in semiconductors, and with Professor Frauenfelder of the Physics Department on studies of the effect of presture on the kinetics of henoglobin. A new collaborative effort is planned together with Professor Beck of the Metallurgy Departaent to atudy the effectu of preegure on the behavior of mictonagnetic alloys. 


\section{Publicationg: (Calendar Year 1975)}

V. H. Cheng, P. C. Allen, and D. Lazarus

Pressure Coefficient of Thermolectric Power of Platinum/Platinum-10\% Rhodium and Chromel/altumel Thermocouplea

App1. Phys, Lett, 26, 6-7 (2975)

H. M. Gilder and D. Lazarus

Role of Vacency Anhartonictity on Non-Arrhenlus D1ffueional Behevior

Phys. Rev. B11, 4916-4926 (1975)

Joan L. Mitchell and David Lazarus

Effect of Heterovalent Impuritlea Codiffuging with Monovalent Tracers in Ionle Grystala

Phys, Rev, B12, 734-752 (1975)

R. J. Nelson, N. Holonyak, Jr, W. R. Hitchens, D. Lazarus, and M. Altarelli Pressure Experiment Determination of the Direct-Indirect Transition in the Quaternary $\mathrm{In}_{1-x^{\mathrm{Ga}}} \mathrm{P}_{1-z^{\mathrm{Aa}}}$

Solid Stace Commun. (submitted to)

Also supported by ARPA (AFOSR), NSF and ARO(D)

M.S. Thesea: (Calendar Year 1975)

None

Fh.D. Theses: (Calendar Year 1975)

None 
Properties of NobIe Gas Crystals

Princtpal Invest1gator: Ralph O. S1monons, Fh.D.

Professor of Physics;

Head, Department of Physics

Supporting Agency: v. S. Energy Research and Development Adainistration

Sentor Staft: Ralph O. Simons, Profess or

Dona1d R. Baer, Research Asboctate

Junior Staff: Benedick A. Fraass, Resesch bagietant

Steve M. Hea1d, Research Assistant

Albert T. Macrandex, Research Aesistant

Object: There are four different goals of this regearch program: 1) to deternine the structure of thermal defects in quantun crystals and to elucidate the mechanisms by which atomtc diffugion takes place, in a regime dominated by quantun effects, 2) to discover and to characterize the nature of solid-solid phase transitions in simple molecular crystals having orientational order as a major contribution to crystal properties, 3) to understand phonon-phonon interactions in Insulating eryatals having large lattice anharmonicities, and 4) to Investigate the origing of apparent anomalies in the low-tenperature thermal properties of low-density quantum solids, particularly bec ${ }^{3} \mathrm{He}$.

In all four ceses, crystals of condensed gases are chosen as the solld natertals for atudy, becsuse the physical phenomena arlae, in such natertals, In extretne form, better separated from other ffects. The phenonena cas be studied in such materialis over an especially large range of physical cond1tions: factors of more than a hundred $1 \mathrm{n}$ temperature and changes up to forty percent in aolid density: Another significant advantage of these materials, as model systems for the atudy of solid state phonomena, 1s the relative esen of controlifing their purity and prectiely analyzing their impurity content. Finslly, tsotopic substitution can be used to separate physical and chemical effects and to probe altemative atomic mechantems.

To pursue these goals, using these materials, provides formidable technical challenges and often requires the invention of new types of apparatus, and sdaptations of these techniques have given other scientists the mans to carry out research in other areas of uaterials acience.

Achleving, the first goala, the determination of thermal defects in quantum crystals, requires a direct method for measuring defect content. For vacancy-type defects in ustul solids, differential comparisons of macroscopic length and $x$-ray lattice paraweter chenges have been demonotrated effective by the princtpal Investigator in metals and in metallic 
slloys. The current work extends and siaplifies this method by confining the spectmens at essentially constant volume, so that x-ray lattice parameter changes alone are sufficlent. This almplification increases the sensitivity of the method and reduces amblgulties in interpretation, This ts twportant because current thearies of these thermal defects suggest that they are not localized point defects, but rather, are nonlocalized: in extrene view, are "vacancy waves."

The literature of atonic diffuston contains speculations about many possible mechanisms and accounts of measurements using meny physical probes of atom1c jumping processes. By now, atonic mobility is understood phenomenologically in many well-characterfzed gystems. In others, complexity due to the appearance of competfng classtcal processes obscures detafled understanding. As the mraveling and application of classical explanations has proceeded, interest in quantum manifestations in acomic nobility in solids has grown. L1ght impurfties which sit off-center in crystalline sites, and tunnel between equivalent positions or ortentations, have been one $k 1$ ind of systen studied. There are technologlcally luportant exauples, such as the hydrogen In nioblun systems Investigated locally by A. C. Anderson, H. Blenbaum, C. P. Flyns, and M. V. Klein. But model systems chosen for sclentif1c, not technological reasong, are slso necessary, 1n order to explote more readily the full range of real posstbillties whtch may need to be fnvoked in understandfng, and possibly controlling, atonf mobility in matertals.

The nost extreme cases of atonic mobilfty occur in solfd helium, especta1ly bec ${ }^{3} \mathrm{He}$ at low denstties. Crystalline binding is so weak, and the atoms are so 1 ight, that atoulc mobilfty is easily measurable even in the limit of extreme low temperature. Quantun excitation of atoxic mobflity ghades, at h1gher temperatures, 1nto thermal excitation. Because of the great compressibility of this material, studies can be conducted over a large range of interatomic interaction strengths, without chevical alterations.

The second goal, characterization of some solfd-solid phase transitions due to molecular rotational ordering, is intended to fork a testing ground for modern theories of phase transitions in situation of controlled cotplexity. By "controlled complexily" is meant: the number of variable features is limted, but the relative sizes of different possible contributions are coroparable so that the resulting phenowena depend vary sensftively upon the magnitudes of these contributions.

Sol1d thethanes are attractive model systems for these purposes, Cotunting 1sotopic substituted (deuterated) cases, there are five different methanes. They ghow certain systenat 1c features in the phase transitions of the pure methanes and of thelr mixtures. All the molecules are simple electron closed-shell conflguration. The crystal phases are nostly cubic. Yet total nuclear spin and molecular rotational moments of inertia can be varied over a broad range. And a wide varlety of experimental techniques ( $x$-ray. neutron, HNR, optical, calorimetric, dielectric, and spectroscopic) can be applied. 
The third goal, understending anharmonic1ty in insulators, is a tradithanal one, first ralsed clearly by Max Botn aluost forty years ago. But advances in microscoplc understanding are confined to the lat decade. Dur own contributions in this area have been made by showing that precise messurements on noble gas oolide ate possible and, fron the results of such seasuremente, severe constra1nts are put upon the acceptability of theoretical formulations of the problem. These close constraints have proven useful in a situation where good knowledge of the interatonic interactions can be appiled to discern an Inadequate formulation of the theoretical treatnent, contrary to the usual sltuation where they are intertuined.

The practical importance of lattice anharmonictty in electrical insulators arises, of course, fron the fact that 1t provides a mechanism for the transport of heat and it gives rise to thermal expangion, to temperature dependence of the elastic properties, etc. Applications of solld naterials in technology, not only for mechanical construction but also for component elements in solidrstate electrical devices, often depend upon the therpal properties of these meterials.

Our studies of thermal expansion and of elastic properties have been complemented by Raman scattering measurements in pure noble gas aolids and in their mitures. The latter yleld essentially direct information about the lowst order anharmonlc lattlce properties.

The fourth goel, Investigation of anonalies in the extreme low-temperature thermal properties of solid 3 le at low densities, artses becouse aimilar apparent anomalies may appear in disordered insulators such as glasses. As knowledge about regular crystaline materials has accumulated, scientific interest has increasingly shifted to disordered systens. At the same twe, the Importance to technology of certain disordered or quast-amorphous Insulatorg (1ncluding optically transparent ones) and seulconductors has risen.

Whether the sources of these apparent anomalles in solid helium are static or dynamic, intrinsic or extrinsic, is unknown. Existing calorinetric and elagtic data are not compatible, except through ad hoc relations. We want to use well-characterized crystalline specimens to sea whether the apparent anomalies persist under such conditions. We balteve that $x$-ray diffraction and scatering techniques are the beet way to proceed.

Results, FY 76:

Most S1gnificant Accomoliahnents: The activation energies for focmation of thermel vacancles have been measuted for bce ${ }^{3} \mathrm{He}$ over the range of molar volumes 19 to $24.5 \mathrm{~cm}^{3} /$ mole. They are essentially identical to diffusion energies determined by MaR methods over the range 19 to $23 \mathrm{~cm}^{3} / \mathrm{mole}$, which demonstrates that thermal vacancy motion occurs by a tunneling mechanism. The defect energies are lower than those previously inferred Indirectly from heat capacticy nessurements at large nolar volunes. A train of argument, based upon the directly measured vacancy content, leads to 
an estimate of the "band width" of the "vacancy waves." The Eolat volume dependence of the vacancy fotmation energy can be analyzed to obtain the first direct measurement of the volune of formation of these (someshat nonlocalized) thernal defects.

0ther Results: Preliminary measurements of thernal vaconcy anorgfes in hcp ${ }^{3}$ he (again compared to WMR work) show that, unlike non-close-packed bcc ${ }^{3} \mathrm{He}$, vacancy migration involves thermally-actlvated hopping over a barrier.

Our preclse lattice parameter neasurements and thermal drift studles in solld $\mathrm{CH}_{4}$ and $\mathrm{CD}_{4}$ have produced many results.

a) The upper phase transitions in both $\mathrm{CH}_{4}$ and $\mathrm{CD}_{4}$ are first-order, contrary to most previous experiments, and the characteristic time constants in pure material are extremely long (days to weeks).

b) The latent heats of these upper transitions can now be detarmined with some consistency.

c) In $\mathrm{CD}_{4}$ the lower phase transition is to a tetragonal phage, itg parameters have been accurately determined down to $4 \mathrm{~K}$, and 1 ta habit of formation from the adjacent cublc phase observed.

d) In $\mathrm{CH}_{4}$ no Lower structural phase transition appears at low tenperature, but the crystal ahous negative thermal expansion, which can be explained by the conversion of spin isomers on the disordered sublattice.

e) Thermal drift weasurements have established the 1dentity (contrary to reports in the 11terature) of the structural and calorimetric transition temeratures.

f) The equilbrium thermal expansion coefficlents have been determined In both $\mathrm{CH}_{4}$ and $\mathrm{CD}_{4}$, and $\mathrm{R}$. J. Heyer (of W. L. Mcllllian's group) has devised a Landau theory of the upper transition (the order parameter of his theory is a third-rank tensor 1).

The experimental part of our Ranan gcatter1ng work, in cooperation with M. V. Kletn, has been completed on argon and argon-krypton mixtures ac a range of pressures up to several kilobars. The neasurements extend up to $50 \%$ greater frequency ahifts (i.e, to much weaker scattering) than prevtous work in other laborator1es. Prelininary interpretations of the "one-phonon" and "two-phonon" spectra have been made and were reported verbally at APS metings; manuscripts are in preparation. The "two-phonon" spectrs are fafrly direct evidence about enharmonictiy whtch can be used to check current "self-conststent phonon" theories. 
Results Expected, FY 77: Successful thernal vacancy studieg on pure bcc 3he lnvite serlous actempts to discover modificatione of these effects In ${ }^{3} \mathrm{He}-^{4} \mathrm{He}$ mixtures, which have been the subjects of many MRR gtudies. The ron-localized nature of the thermal defects should be influenced not only by the masaes of the atoms but also by their differing statlatics. These effects, if observable, may be a way to sort out the microgcopic nature of the defects; as non-localized defects ("wave packets"?), the basis states, ag it were, may form a very novel set.

The verification of tunneling as the migration mechantso for the thermal defects, and the deteruination of the defect volune of fornation in bcc ${ }^{3}$ He, leads to confidence that the hep ${ }^{3}$ He phase mexita more 1nvestigation, because it is clearly qualitativaly different (yet the same chemically). X-ray measurements of thernal defect content in hcp ${ }^{3} \mathrm{He}$ and hep ${ }^{4} \mathrm{He}$ will be made. With luck, sone 1dea of the processes of vacancy generation/annthilation at dislocetion sources/ainkg can be obtalned by cowparing the relative changes in axial and orthogonal lattice parameters in the hap phase.

An Inventory of phase transitions in other crystals, besides the methanes, composed of tetrahedral molecules has already been made. The value of prectse $x$-ray lattice parameter work on several of these more complex crystals, versus the value of Debye-Waller $x$-ray, elastfc wave velocity, compressibility, and/ar thermal drfft measurements on the methanes will be decided. It will be necessary to purgue some theoretical analyass for a oignificant tine during this time period before it is known whether the many experimental results obtained during FY 1976 are declstve for the understanding of the structural orlentational ordering.

Our dilution refrigerator cryostat will be used to carcy out $x$-ray scattering and diffraction atudies in bcc ${ }^{3}$ He in the range 0.04 to $0.6 \mathrm{~K}$, in pursult of structural characterization of the apparent thernal anomalles observed previously by others.

The question of charged defecta in these 1nsulators will be explored. Phase equilibration phenomena will be explored, both in the methanes near solid-solid trangitions and in the hellums near the melting line. Relations to phenonena in amorphous materials vill be sought.

One activity, for which our group has been approsched in the past, but whtch we have not had much capacity to respond to, is "service" or cooperative projects dependent upon our high-prectsion $x$-ray cameras, diffractometers, and versatile cryostats. It 1s likely that during FY 1977 we can begin to respond to such requed fo fot other MRU personnel in selected cases. Our apparatus can be applied, of course, to essentially any crystalizine materials.

Results Expected, FY 78: The natures of the thernal defects in soldd heliut and in solid helium uixtures appear so unusual thet the regults of continued budy are quite unpredictable. It does appoar likeiy that the useful $x$-ray studieg of these phenonena will not be completed during FY 1977. 
Should "glassy" properties be discovered in our crystalline ${ }^{3} \mathrm{He}$ at extreme low temperatures, attemta at elucidation of that would extend Into FY 1978.

High temperature materials remain planning target for us. We hope to apply our expertise obtained in phase transition studies on the pethane systems.

Relationshtp to Other Federally Funded Projects: Studies of self-diffusion, atomfe, or tonfe transport in quantum crystals are presently carried out at the Unfversity of Massachusetts, CaseWestern Reaerve, Bell Laboratorfes, the Un1versity of Sussex (United Kingdom), CEA Saclay (France), Ingtitute of Physical Problems (Moscow), the Phys1co-Technical Ingtitute (Kharkov), and occaslonally elsewhere. The speculative content of current theoretical fortulations is presently large. There 1s a clchness among th1s speculation, however, which encourages hope that some truly new phenomena will be identifted and established.

Studies on phase transitions in solid methanes are presently carried out at Harvard Untverstey, the Untversity of Calffornia, Berkeley, MuMater Universtey (Canada), the University of Toronto, KFA Julich (Germany), Grenoble (France), and several Japanese laboratories.

Raman scatter1ng studies on noble gases and the1r ulxtures have been carried out at Bell Laboratories. Brillouln scattering work has been done at the Untversities of Toronto (Canada) and Muntch (Germany). Theoretictl and computational work of greatest recent slgniflcance has been produced at IBM San Jose and at MRC Ottawa (Canada). Phonon dispersion han been measured at Brookhaven National Laboratory.

The thermal anomalles in bec Hite were discoveted at the Anes Laboratory and confirmed later at the University of Florida. Speculation about the posstble ortgins of these anoualies has cone from phyolctots all over the world.

In all the above cases, theoretical and experimental work on the systens c1ted, In the $U$. S. national laboratories and in U. S. Universities (and Indeed the other 1abs, too), complenents the present project but does not duplleate any portion of $1 t$.

Publications: (Calendar Year 1975)

V. $M$, Cheng, W. B. Dan1els, and $R$. K, Crawford Melting Parameters of Methane and Nitrogen from 0-10 Kilobarg Phys, Rev. B11, 3972-3975 (1975)

Also supported by NSF GP-7739 and GP-1B573 (U. of Delaware)

R, K. Crawford, W. B. Danfels, and V. H. Cheng Melting and Its Relation to Molecular Orientations in the Fluid and solid Phases of $\mathrm{N}_{2}$ and $\mathrm{CH}_{4}$ Phys, Rev, Al2, 1690-1696 (1975)

ALso supported by NSF GH-32491X and UnIdel Foundat1on (Delaware UnIverg1ty) 
R. K. Crawford, W. F, Lewts, and W. B, Daniels

Thermodynamics of Solid Argon at High Temperatures

Solld State Phya, C (to be published)

Also supported by NSF Gd-32491X

L. A. Schwalbe

Bquilibriun Vacancy Concentration Measurements in Solid Argon

Phys. Rev. B (to be published)

M.G. Theges: (Celendar Year 1975)

None

Ph.D. Theses: (Calendsr Yeat 1975)

D. R. Aadsen (R. 0. Stmons, Adviser)

Lettice Parameter and Thermal Expansion in solid Methane October 1975 
Nuclear Magnetic Resonsuce in Sol1ds

Princ1pal Investigator: Charles P. Slichter, Ph.D.

Professor of Physics

Supporting Agency: U. S. Energy Research and Development Adufnistration

Senior Staff: Charles P. Slichter, Professor

Stephen F. Heyer, Research Assoctate

Junior Staff: Daniel Abbs, Research Assistant

Thomsis J. Aton, Research Assistant

Stephen H. Couturle, Research Assistant

James P. Long, Regearch Ass Istant

Howard E. Rhodes, Research Ass istant

Object: (A) Magnet1c Atoms in Mon-Hagnettc Metals. We are studying two broad aspects, which, however are closely related: (1) the Kondo effect, a challenging many-body problem; and (2) the general nature of electronic structure of the magnetic atons.

The kondo effect is an important theoreclcal problem both because the theoretical problem is stmilar to ones encountered in other parts of physics, such as the explanation of the effect of electron-electron interactions on the optical and x-ray properties of solids, and because it has led to discovery by Wilson, Krishad-murthy, and Wtlkins at Cornell of important new theoretical nethods for dealing wh solids.

Our experiments consist of studying the nuclear resonance of $\mathrm{Cu}^{63}$ nuclel which are near neighbors of iron group atoms present in dilute alloys (.01\% to 1\% atonlc fraction of iton group atows in copper). The magnetism of the iron group atom induces a cloud of magnetization in the conduction electrons in the vicinity of the iron group atow. Our measurements enable us to produce a map of that induced magnetization at, In some cases, five or six nearby shells of cu nuclei. From such neasurements it is possible to deduce the energies and widths of the energy levels of the Iron group atoms, information which has pot heretofore been measured. These results are basic to understanding the magnetic properties of the Iron group atoms: why $\mathrm{Cr}$, Mn, and Fe are strongly magnetic in $\mathrm{Cu}$, whereds $S c, T 1, V, C o$, and $N 1$ are not.

Recently, Wilson, Krishna-murthy, and Wilk1ns have shown how to predict the observed kondo effect starting from a simplifled pleture of the magnet1c atom, making assumptions only as to the energy and width of the energy levels of the magnetic atom, just the quantities our expertments are able to provide. Their model is simplified in the sense that it assumes the magnetisn artses fron s-electrons, whereas in fact it arises frots d-electrons. If the theory can be extended to treat d-electrons, the theory will provide a complete first principles prediction of the Kondo effect to test againat neasurements. The 
weasurements we are carrylng out will provide knowledge of the laput data about the magnetic atom which, when used, leads to a definite prediction of the Kondo temperature. Conparison of the predicted and measured Kondo temperatures would thus provide a complete test of such a first principles theory, We are fortunate in having recently received acceptance by Dr. Krishna-murchy of a postdoctoral position at Illinols.

We belfeve such a test would make a signiflcant contribution to understanding baste properties of sollds. It will also provide an upderstanding of the Kondo effect at a vastly deeper level then had previously been thought posalble.

(B) Transition Metal D1chalcogenides Layer Cobpounds. The transition metal dichalcogenide layer compounds such as $\mathrm{TaS}_{2}, \overline{\mathrm{TaSe}}_{2}$, and $\mathrm{MbSe}_{2}$ possess remarkable properties. Consisting of planes of transition metal atams sandwiched between planes of the dichalcogentde: (1) they are superconductors; (2) they can absorb large amounts of foreign molecules (easfly doubling the number of atons in a sample), a process called intercalation; (3) their superconducting transition temperature, $T_{C}$, is tuneable by selection of the molecular species intercalated as well as the rat 10 of intercalate to host spec1es; (4) they exh1bit charge density waves (CDW'a), a remarkable gtate in a conductor in which the electron charge density possesses standing waves in contrast to 1 ts usual uniform density characteristic of most metals.

We feel these compounds are fnportant to study both because of the light they may shed on the practical problew of how to raise $T_{f}$ of a ouperconductor, but also because, as the flrst naterfals known to exhibit charge densfty woves, they have opened a new fleld of toportant new sclence related to electrical conduction. They are closely related to the phenomenon of spin density waves (exhlbited by $\mathrm{Cr}$ ) which $1 \mathrm{~s}$ an Important cause of magnet 1sm. Thus, we judge that these cotpounds provide an excellent chance to explore new realms of electrical conduction, superconductivity, and wagnetism, all important fielda technlcally for production and transmission of energy.

We are scudying aspects of intercalation and of charge density waves.

In the area of intercalation, Dr. Meyer of the resonance group is studying $\mathrm{TaS}_{2}$ containing $\mathrm{H}$, a system he studied for his Ph.D. thesls at stanford. He found that intercalation by $H$ causes the superconducting transition temperature, $T_{c}$. to go through a maximum (with $T_{f}$ nearly three times as high T1 for pure $\mathrm{TaS}_{2}$ ) as the $\mathrm{H}$ concentration is increased. He poatulated that as the $\mathrm{H}$ atons go Into the $\mathrm{TaS}_{2}$, they give up their outer electrons to the conduction band. As more hydrogen goes in, the Ferml energy rises through the conduction band. According to the BCS theory, $T$ dependa on the denstly of states at the Fermi energy, $N\left(E_{\mathrm{F}}\right)$. Meyer suggested that $1 \mathrm{t}$ is the variation of $N\left(E_{\mathrm{p}}\right)$ as the $\mathrm{H}$ electrons fill the conduction band which is responstble for the change in $T_{c}$. 
We are measuring the proton spin-lattice relaxation $r$ ate since the contribution of the conduction electrona to that quantity is proportional to $N\left(E_{F}\right)$ giving us a means of testing the proposed explanation for the variation in $\mathrm{T}_{\mathrm{c}}$ on intercalating hydrogen.

We are studying charge density waves. The wavelength of a charge density wave is found at the lowest temperatures to be commensurate with the lattice (e.g. thice tines the lattice congtant) but at sowewhat high temperacures it is incommengurate. The earitegt view of the incomensurate wave was that it was a pure stnugoldal nodulation whose phase, therefore, . slipped in a regular manner with respect to the lattice as one moved along the charge density wave. Professor McMillan of our department has proposed an alteraative picture, that the Incomensurate phase consists of a charge densfty wave which is commensurate except over a amall region over which there is a phase slip. He calls thege reglons of phase slip "discomengurations." Such a picture is similar to the way a dislocation accounts for silp. It should be possible to diatinguish the two proposed pictures by NTR. For a comensurate $C W W$ in $\mathrm{TaS}_{2}$, there should be a set of discrete Talol NRR I1nes, one for each distinct postition of a Ta nucleus on the wave. If Mclilian sicture of discomensurations is correct, these MR ines should persfot when one passes into the Incomensurate phase, since most Ta nucled will be in a conmensurate region. But if the CDW is unifornly incommensurate, the IDR Iines will congist of a smooth smeat. Thus, the spectra differ in the two cases.

(C) Catalysis. The successes we have had in our studies of dilute systems of magnetic atoms in non-magnetic netals have stinulated our Interest in other areas of najor sclentific and practical inportance requiring high sensitivity in detecting nuclear resonance. We are currently tnvestigating potential problems in catalysis, an area which Is vital to many arees of phystcs, chenfstry, and blology and of particulat Importance to production and usage of fuels.

We have chosen sn 1nitial experiment which conbines high interest with relatively low risk-the study of platinum catalysts, supported on alumina, on silica, or on mixtures of alumina-silica.

These catilysts, which are of great practical importance in the so-called reforming reactions with hydrocarbons, typtcally consist of small particles (10-50 $\AA$ diameter) of platinum, supported by the insulating aluoina or silica. For such particles, a large fraction of the atoms are on the particle surface.

Although typically che platinum atoms are less than $1 \%$ of the atom numbers In the catalyst, we belleve the fraction of atoms on the surface is sufficiently large that there is a good chance of seeing their resonance using the senstive methods we have prevlously employed. 
Platinum, beting a spin $1 / 2$ nucleus, is not troubled by quadrupole interactions, but tis very large Kuight shift of geveral \% should be different for surface atoms from those on the interfor. Horeover, depending upon what crystal face forms a surface, the Knight ohift might differ.

If we can find surface aton resonances, the way is then opened for observing changes in then when another atom is bonded at that site and In fact should depend upon what atom is bonded. There exists, then, a potentlal route to.learn about the surface couplings to molecules involved in catalysis.

The potential applications seem very large, but depend upon success of the f1rst stages. Note that so little has ever been measured on auch small particles that they are of wajor gctentific interest quite apart froto their role in catalysis.

We have observed the Pt rewonance in 1000 particles. We have had an interesting and fruitful Interaction with Dr. John Sinfeld of Exxon, well known for his ploneering studies of catalygts. We have met with h1 in and discussed our concepts of what one wight leatn fron nuclear reapnance studfes. Following these discussions, the kindly prepared a set of samples for us consigting of Pt particles on alunina, the different : anples differing in Pt radius. The radil go from 10 in a sanple to 40 In another. We are currently working on these sauples.

(D) A New Method for Electrical Conductivity Messurementg. The conventional method of measurfing electrical conductivity is the four probe method. In the last several years, the subject of conductivity neasurements has incerested many people becauge of the surprisingly bigh values reported by Heeger and his colleagues for the highly anisotrapic organfc electrical conductor TTF-TCNQ at temperatures near $80 \mathrm{~K}$. He suggested there might be a relationghip of his results to stper conductivity. Other workers proposed that his results were artifacts of poor or misaligned contacts in his four probe experiments: Stinulated by the potential importance of understanding the conaluctivity of compounds Buch as TTF-TCNQ, we have devised a new method for measuring conductivity, one whtch will enable us to use a moving contact and thus to provide a self-check which we hope w1l assure chat the results are valdd.

The method fovolves putt1ng the sanple in a scanning electron microscope. Two contacts are attached to the sample. One is connected to ground. A voltmeter (actually a lock-In anplffier driving a chart recorder) is connected between the other and ground. Current is injectad toto the sample by the beam of the interoscope. Modulation of the beam posttion along the sample modulates the voltage neasured by the voltneter. The change in voltage for a glven modulation amplitude and for a known current gives one the conductivity. Since one can move the bean continuously around on the crystal, one can check that the current flow patterng are well behaved, or whether, perhaps because of Elcro-cracks or poor contacts, they are not. 
Results, FY 76:

Most Signiflcant Accomplishments: (1) We have shown that our meapurenents In powders and single crystals of dilute alloys CuFe easble us to deternine the electronic structure of the Fe atom $1 \mathrm{n} \mathrm{Cu}$. This has never been done before for the Fe group atoms in non-nagnetic hosts. Speciftcally, we have deduced the position of the energy levels, the width of the energy levels, have shown that there $1_{\text {f }}$ a crystal splitting of the iron d-ievelo and have measured it, and that the $F e$ atom has $7.0 \mathrm{~d}$-electrons. We have thus evaluated for the first time the quantities involved in $P$. W. Anderson's theory of magnetic atoms in non-magnetic matals.

These results have added g1gnificance as a result of the buccese of wilson, Kriahna-nurthy, and Wilking in showing how, given inforwation such as we have obtalned, one can predict a kondo effect and calculate a Kondo teuperature to compare with experiment. As yet their theory does not apply to d-electrons as is necesgary to discuss the experiment, but if It is posible to extend their theory to d-electrons one will have achleved a first principles understanding of the Kondo effect ot th all quantities which go Into the theory or are predicted by the theory known from experfment. Such a theory, using our experimental results, would achleve a depth of understanding of the kondo effect which no one dreaned would be posstble several years ago, truly a najor advance in understanding magnetton.

(2) We have succeeded in carrying out single cryotal studies of the dilute alloys CuCr, and Gutr. As a result, wa have high hopes of deducing the sane Information for these alloys that we have for CuFe--nanely, the decalls of the electrontc structure.

(3) Our results for Cuco single crystals prove unequivocaliy that one must Include a crystal splitting of the Co energy levels to understand the nagnetic properties of Co in $\mathrm{Cu}$. As mentloned above we find that we also need a crystal splitting to explain the Cure data and deduce the s1ze of the splitting. We hope to deduce the size for Co as well.

These results are the first proof of the fmportance of cryatal splittings In understanding the magnetic properties of tron group atoms in metals.

(4) We have studied the system CuCr fron room temperature to liquid neon Lemeratute (about $27 \mathrm{~K}$ ). Our studies demonstrate that etther the susceptibility deviates aignificantly fron the usual Curle-Weiss law obeyed by other magnetic atons in non-nignetic hosts, or else the previously deduced Kondo temperature of this aystem is in error.

Other Results: (A) Iron Group Atoms in Cu. In add1tion to the results described above, we have coupleted studles of the systemis Cufc and CuT1. We find that they are very weakly magnetic, comparable to Cuiti. We have proved the correctness of our conjecture that the CuSc samples contain Cu resonance from the compound CuSe as well as from Cu nesr to liofated Sc atons. Thus, our KMR data give aetallurglcal data for the cuSc system as to solibflities just as they did for curv. 
(B) Transition Layer Dichalcogenides.

(1) Intercalation. We have prepared a sertes of aamples of $\mathrm{TaS}_{2}$ contalning different concentrations of $\mathrm{H}$. We have begun measuring the proton spin-lattice relaxation time, $T_{1}$, and the relaxation tine $T_{1 p}$ for these samples over temperature range from $1.3 \mathrm{~K}$ to $300 \mathrm{~K}$. We observe a conduction electron contribution for the samples ve have completed. We do not as yet fully understand the data, but expect to be abla to as we complete the data collection.

(2) Charge Density Waves, We have grown single crystals of TaSe2 and $\mathrm{TaS}_{2}$ to look for the Ta and se resonances. In the TaSe2, we have observed the Se resonance using a magnetic field of 10,000 gauss, at $4.2 \mathrm{~K}$ and $300 \mathrm{~K}$. Selentum has a nuclear spin of $\mathrm{v}_{1 / 2}$. It could in principle reveal a charge density wave through the effect of the CDH on the knight shift. Each distinct Se location in the CDW should have a cheracteristic Knight shift, giving rise to structute on the Se MTR. At $10 \mathrm{k}$ gaues we do not detect any such structure. He will use our superconducting solenotd to 80 to $60 \mathrm{k}$ gauss to enhance any splittings which might exist.

(c) Catalysis. We have prepared samples of $1000 \AA$ Pt particlea in 1ight oll, and have observed the Pt nuclear resomance in them. We are Invegtigating means of optinfzing the slgnal to nolse. We have had discussions with Dr. John Sinfeld of Exxon, an expert in catalys 1s, who has provided wo with several well-characterlzed samples for study. We are currently Investigating them.

(D) Electricsl Conductivity of TTF-TCNQ. We have designed and constructed a cold stage to enable us to study the conductivity of TTP-TCMQ Bingle crystals in the scanning electron microscope as a function of temperature. We have carried out studles ta determine the optinum beam current and bean voltage for these studies to take account of possible radiation damage to the sample, and gecondary electron emisalon. We have also perfected an electronic beam allganent method to enable us to make fine adjustments of the direction of beam modulation with respect to the physical orfentation of the crystal.

Results Expecced, FY 77: (A) Dtlute Alloys of Iron Group Atong in Cur. We hope to determine the energy levei structure of Mn and Cr atons in $\mathrm{Cu}$ by analysis of our single crystal data. These data w11l serve as input to a theoretical prediction of the kondo temperature for these aystens 1f the theoriats can extend the results of Krishnamurkhy, Wilson, and Hilkins to d-electrons.

As part of the results on the electrontc structure, we hope to deduce the crystal splittings of the d-states, and the number of d-electrons these atoms possess when in $\mathrm{Cs}$. These results have never been know before. 
At present the Kondo temperature of the system CuCr has been deduced only sonewhat indirectly through spin transmission weasurements. Our experiments on CuCr have shown that either the value deduced is incorrect, or else there are substantial deviations from the usual Curle-Weiss behavior. We will try to settle this question by carrying our satellite studies to liquid heliun temperatures.

(B) Transition Metal Dichalcogenides.

(1) Intercalation of Hydrogen. We expect to complete our studies of the NMR of protons, to see whether or not the data support the prior conjectures as to why intercalation with hydrogen changes the superconducting transition temperature.

(2) Charge Density Waves, We w1ll study the Se resonance at $60 \mathrm{k}$ gauss In single crystals of $\mathrm{TaSe}_{2}$ at $4.2 \mathrm{~K}$ to see whether or not there is resolved structure Indfcative of the existence of the charge density wave. If there is, we will go to temperatures in which the charge density wave is 1ncoumensurate with the lattice to test Mcililan's theory of how the incommensurate wave fits into the lattice.

We will continue our search, so far unsuccessful, for the Ta nucleat resonance.

(C) Catalysis. Essential to our plans is observation of the Pt resonance in very small particles such as those provided us by Dr. Sinfeid. We wll try to observe the Pt resonance in these samples. If successful we wll search for surface resonances.

If not successful, we will prepare samples of larger radfus to find shat happens to the resonance as the radlus decreases, and thus to see what we must do to find the resonance in very small particles.

(D) Conductivity of TTF-TCNQ. We expect to complete conductivity experfinents on a group of single crystals to determine the frequency and charactertetcs of erystal Imperfections which distort the current flow pattern from the Ideal, and to use data on crystals whose flow pattern we know to be Ideal to messure conductiolty versus tenperature.

Results Expected, FY 78: (A) Magnetic Atows in Non-Magnetic Metals. There is a substantial chance that we will wish to do further data analysis of data we are currently taking, and theoretical work to explain the data. For example, we have data on pseudodipolar and electric quadrupole couplings which shoutd provide independent evidence on the electronic structure of the magnetic acome. We have concepts which we think will account for these data, but they Involve computing out numerlcal integrals.

Thus we hope to understand why the pseudodipolar and electric quadrupole couplings have the values they have, and to use those values to confirm the electronic structure of the atoms. 
(B) Transition Metal Layer Compounds. Some important scientific questions about the transition metal layer compounds are (1) what is the amplitude of charge denstcy waves, and wat determines the smplitude, (2) bow do incomensurate charge density waves fit into the lattice, (3) what are the dynatical characteristles of charge density wavas, and (4) is the existence of cherge density waves and their corresponding lattice distortions related to the existence of superconductivity as has been suggegted night be true for the A-15 compounds.

These several questions indicate the importance of being able to deduce the amplitude and detalled form of charge density vaves, exactly the sort of information we sre study ing by nuclear magnetic resonance.

Two key aspects for such work are the use of single crystals (which we are dolng) and observation of the appropriate nuclear resonance. We are placting heavy ewphasis on f1nding the Tal91 nuclear resonance, because we expect it to have large electric quadrupole coupling, thlch would make it espectally suftabie for atudying charge density waves. Our heaviest ewphas is will be on finding and using the Tal91 resonance to study the charge dentily waves.

(C) Catalysia. We plan to continue work on catalysis using large surface area (small particle) catalysts. S1nce we are gtill in the opening 8 tages, we do not get know what the opportunities w1ll be. But we belleve magnetic resonance has great potential for studying the structure of catalysts. thengelves, or deducting the chentcal spectes witch exist during catalytic steps. We will push this work as fast as technical progress peraits.

(D) One Dimenatonal Conductors. At present it is not clear whether or not the conductivity of these materials can be understood as simple one-electron conductivity, or perhaps requires collective processes. What chance ve have to help resolve these watters depends on the quality of results wa obtain this spring. We will exploit to the full the unlque features of our wethod (1) that $1 \mathrm{t}$ can observe whether or not the current flow is well-behaved (1.e., not subject to the lead misalignment errors which can plague the conventional methods), (2) that it can measure local conductivity, thus detect high values which injht be associated with espectally perfect portions of a crystal, and (3) that we inject through the surface layers by use of appropriate electron energies.

Relationghip to Other Federally Funded Projects: We have an informal relationship with Professor Geballe's group at Stanford who are doing work on transition thetal. chalcogonides. Dr. Meyer, of our group did his Ph,D. on these compounds with Profegsor Geballe. We use ifferent experimental methods, so the sork 19 conplementary.

We are in cloge concact with Dr. Follstaedt and Dr. Marath of Sandia who are working on magnetic atoms in non-magnet1c hosts. We are also exchanging linformation vich Drs. Krishna-murthy, Wilkins, and wilson at Corneli on the relation of our experinents to their Kondo theory.

We are collaborating with Professot W. Motilllan of our own department who-is dolng theoretical work on these substances, and with Frofessor F. Brown who is planning to study Fernt surfaces valng photoentssion of electrons. 
Publicatlons: (Calendar Year 1975)

Charles P. Silehter

Sone Scientific Contribution of Hexbert $S$. Gutowsiky

J. Magnetic Resonance 17. 274-280 (1975)

James B. Boyce and Charles P. Slichter

Conduction-Electron Spin Density Around Fe Impuixitles in Cu Above and Below the Kondo Temperature

Phys. Rev. (subnttted to)

J. B. Boyce and C. P. Slichter

Determfnation of the Energy Level Parameters and Crystal Field Splitting for Pe In Cu

P roceedings Conference on Magnetisn and Magnet 1c Materials, Philadelphia, Pa, , 1975 (to be pubilshed)

D. Follataedt and C. P. Silchter

An WMR Search for Charge Dengity Waves.

Phys. Rev. (submitted to)

C. P. Slichtor

MR Studies of the Kondo Effect Revtsited

Proceed1ngs Conference on Magnet 1or and Magnet1c Materials. Philadelphia, Pa., 1975 (to be published)

M.S. Theses: (Calendar Year 1975)

None

Ph,D. Theses: (Calendar Year 1975)

David Mart1n Follstaedt (C. P. Slichter, Adviser)

A Nuclear Magnetic Resonance Study of Dilute Copper-Vanadiun Alloys January 1975 
ED-02-02-04-0 Particle-solid Interactions

Radiation Damage in Solids

Principal Investigator: James S. Koehler, Ph.D. Professor of Phy atcu

Supporting Agency: U. S. Bnergy Research and Development Adninte tration

Sentor Staff: James S. Koehler, Frofessor

Gerhard H. H. Fritsch, Kesearch Associate

Junlor Staff: Walter S. Knodle, Resesrch Asalstant (Term 3/11/76)

Fobert Kozlorskt, Regearch Asgletant

Maria A. Menendez, Resenrch Asatatant

Jamee Watson, Kesearch Asstotant

Objecc: We are attempting to examine point defects and defect cluaters in all tetals. Firet, we study pure metals. We would like to determine the geometrical structure, the formation and migrac1oo energies and the phyacal property changes agocileted with the presence of defects in solids reguiting frow irradiation. We seek general laws. For example, the finding that the tempersture of the higher close pair peak 1o linearly related for all fcc metals to the Debye $\theta$ is a generalization. He want an understanding of this result on an atonic level.

At present has pure fcc metals are reasonably well understood (except gold). We are therefore shifting enphasis to bcc and hexagonal getals.

Once pure netals are reasonably sell understood, we plan to oeek an understanding of the interactiong and interrelations between point defects and 1mpurittes. For exanple: do gaseous impurities alter stage III annealing of copper and ellver? We are doing an trradiation experinent of pure silver at $100 \mathrm{~K}$ and at $10^{-9}$ Torr to answer this question. We need to measure 1opurity intergtitial crapping energies for varlous impurities In both fcc and bcc wetals. At present we know that atomid core ize effects are Important for fcc metsls. We guesa they are not as important for bec netals, but ve need data.

We need geometrical infornation concerning point defecta and defect inpurity clusters which can be obtained if an energy analyzer for the electron nicroscope becones available.

On the theoretical side, we are attempting to calculate the formation energies, the agration energies, and the low frequency rasonent vibrations of intersticialo in bec metals. We belleve that we have acceptable interatonic pocentialo, but further comparison with the data will be required.

We are just beginning to do theory for hexagonal crystals. At present no one knows the interstitial configuration nor do we know how an interatitial migretes in a hexagonal cryatal. For hexagonal metals, ve oust achieve a description which distingulohe forces along the c axis fron forces in the basal plane. 
Results, FY 76:

Most Significant Accomplishments: We have demonstrated that there are two classes of bec metals. One group (nloblum and tron) shows high temperature Stage I annealing $(B O K+20 \mathrm{~K})$. The other group shows low temperature Stage $I$ annealing $(25 \mathrm{~K} \mp 15 \mathrm{~K})$. This probably means that the geometrical structure of the interstitial differs for the two classes. If so, the lmpurity intergtitlal trapping and the vold formation will differ.

Other Resuits: (1) A discrete annealing step was sean in gold at $0.62 \mathrm{~K}$ (BIrtcher, Hertz, Frttsch, and Watson, Gatlinburg Conference).

(2) The properties of divacancles in lead (1.e., the nigration energy and the binding energy) have been weasured by quenching and anneallng.

(3) The avaflable experiments for the Ecc metals show that $\mathrm{T}_{1 \mathrm{D}}$ is linearly related to $\theta_{\mathrm{D}}$ (2.e., the temperature assocfated with the Stage $I_{\mathrm{p}}$ annealing peak is linearly related to the Debye $\theta$ of the metal). (J. Koehler, Gatlinburg Conference). Gold is anonalous.

(4) For the bcc metals, there is also a linear relationship between the tempersture of the highest close pair annealing process and the Debye $\theta$. However, there ara two classes of bce metals. Each class has tts own linear relation. Iron and nfobltm have high close palr recombination temperatures whereas tantalum, tungeten, and molybdenum give a linear relation at lower recombination temperatures. (J. Koehler, Gatlinburg Conference). A theoretical understanding of why such linear relationshipa exist for both $f \mathrm{cc}$ and bec metals has not yet been achleved.

(5) For hexagonal metala, we have showr that the annealing at low temperatures of cadmiutn differs from that of zinc. In addition, some understanding of the strange annealing behavior of cadmium 1rradiated with theragl neutrons at $3.6 \mathrm{~K}$ has been achieved (J. Koehler, Gatilnburg Conference and J. Koehler, Atlanta Meeting, Am. Phys. Soc, March 29, 1976).

(6) Theory: We are making thearetlcal calculations concerning polnt defects 1n bce crystals. A two-body potential is used which contains interactions between nearest and next nearest nelghbors. The constants in the potentlal are chosen to: (a) tit the appropriate Firsov potential at small atouic separations, (b) give the correct cohesfve energy and elastle constants, and (c) join 9moothly together the first nelghbor and the second neighbor potentials at a distance midway between the equilibriun first and second nelghbor distances.

At present we are using the resulting potentials to: (1) determine which interstitial structure has lowest energy, (2) to calculate the Erequencies and the geometries of the low-Iy1ng resonance modes. Thus far, calculations have been carried out for 1ron and tungsten. In Iron the stable interstitial is the split $\langle 110\rangle$ 1aterstitial. In tungsten the stabie interstitial is the spilt <llis interatitial. 
Note that this suggests that a different linear relationship between $T_{h i c p}$
and $\theta$ exists for metals having different stable interstitials.

The finding that there are two different kinds of stable interstitials antong the bec metals is ituportant because the entite annealing behaviot of the two classea of bec metala will differ. Horeover, the interaction of the two kinds of interstitials with 1mputities should differ.

Results Expected, FY 77: (1) We are now electron 1rradiating pure sllver in ultra high vacuum $\left(10^{-9}\right.$ Torr) and at $100 \mathrm{~K}$. We belleve that gaseous 1mpurictes, particularly oxygen, result in complex annealing in Stage III In silver (1,e., 1n the temperature region $-70^{\circ} \mathrm{C}$ to $+50^{\circ} \mathrm{C}$ ). An irradiation has been nade, and 1gochronal annealing studles sre underway.

(2) Gold: Pure goid is befing irradiated at $0.60 \mathrm{~K}$. We wish to determine whether the $0.62 \mathrm{~K}$ step obeys first, second, or third order annealing kInetics (1.e., 1s it a close intersticist vacancy palt recoubination; does it involve three dimensional long-range migration of an interstitial, or is 1t assoclated with long range migration in one dimension?):

(3) Magnes1um: We are electron frradlating pure magneslum at $3 \mathrm{k}$. No careful production or annealing data exists for magneslutm. Magnesiun is nearly close packed. We would 11ke to determine shether the energy required to displace a magnesium atom in the $c$ direction is the same as that required for displacenent parallel to the basal plane. One irradiation has been perforaed.

(4) Cadmium: We have pure cadmium single cryatals. We would 11ke to determine the displacement threshold for displacements parallel to $c$ and to a. Moreover, we would like to find out whether the annealing behavtor changes when first a displaced cadmiun atom does not have enough kinetic energy to penetrate a nelghboring basal plane, and second, the displaced atom has aore than enough kinetic energy for penetration. We have not. as yet prepared single crystal specimens.

(5) Vanadium and Chrotium: These are bec metals and should be in the same class as Iron and nlobium. Klabunde and coltman [Rad. Effects 7 . 325 (1971).] have 1r radlated vanad1um at 3,6 K. They saw continuous anneeling except for a peak at $47 \mathrm{~K}$. It is possible that theis data is influenced by fupurities. We have vanadium of higher purity (prepared by the Ames Laboratory).

Thus far no irradiation or annealing data exists for chroniun. We hope to 1rradiate and anneal 99.9997 pure chromium.

(6) Theory: We plan to calculate for the bcc metals the interstitiaf forwation and migration energies. In addition, we will find the frequency and the symmetry of the low frequency resonane modes. We will begin with Iron and tungsten. We hope that these calculations will confirm our separation of the bcc metals into two classes. 
Results Expected, FY 78: (1) Hexagonal Metals: of the 38 metals in the periodic table which have simple crystal gtructures (fec, bcc or hexagons1), 13 are hexagonal. Thetr melting polnts range fron $692.6 \mathrm{~K}$ for zinc to $3453 \mathrm{~K}$ for thentum.

To date, very little careful 1rradiation and annealing data has been obtalned.

First, we wish to determine whether the energy required to displace a lattice aton differs appreciably with the direction of the impulse. For magnesiun which is nearly close packed and where the core size is small cowpared with the nearest nefghbor distance, one would guess the displacesent energy would not depend strongly on the impact direction (i.e., we expect $E_{d}$ to vary by a factor of 2 or 3 ). For cadritm however, one would expect a larger variation with inpact direction.

Second, for cadniun it is possible that the interstitial occuples a position in between two nelghboring basal planes. If so, it can probably nove thernally more eastly parallel to the basal planes than perpendicular to them. Th1s showld Iead to considerable trappting of one defect by another at temperatures which are low enough that thermal migration in the $c$ direction does not occur. Cadmium and zinc with $c / a+1.87$ should show such effects. It will be interesting to see thether sinilar effects occur for hexagonal metals which are nearly close packed.

Z1rconlum does not show vold growth unless preinjected with hellum. It does, however, have anisotroplc growth under irradiation (1.e., elongation along the $\underline{c}$ axis differs fron that along $\underline{a}$ ).

(2) Elastic and Iaelastic Electron Scattering: We would like to scatter $100 \mathrm{keV}$ electrons from defects in solids. Calculations show that the geonetry of point defects and of defect clusters can be obtatned if the intensity of the elastic scattering between the Bragg peaks in reciprocal space is neasured as a function of the scattering angles $\theta \phi$. We have an electron source, but we need an energy analyzer. Th1s must have sufficient energy resolution to exclude the electrons which auffer plasma losaes (1.e., the energy resolution should be better than 1 eV in $100 \mathrm{keV}$ ). electron scattering has the adventage over $X$-ray and neutron scattering that nore intense beams can be produced and detection and counting are easy.

We would also like to use this instrument to do Inelastlc scattering in which transient defects are generated in solids.

(3) Defect Relaxations: We plan to apply low frequency stresses to single crystals contalning point defects. Such stresses can produce a. preferted orlentation of those defects whose symintry is lower than that of the crystal. We would like to measure the resonant frequency by varying the applied frequency at constant temperature, the damping, and the amount of preferred or ientation. The amount of preferred orientation can be determined by measuring length changes during a cycle. 
(4) Impurities: We belfeve that small core impuritles can trap interstitials securely in close packed metals. We would like to neasure trapping energies by pulse heating to break up the impurity interstitial complex. Subsequent annealing would detect free interstitials. The inttial alloys to try would be copper plus 0.1 at. $z$ beryllium; gold plus 0.1 at. $z$ aluminun; and platinum plus 0.1 at. $\%$ aluminum.

(5) Transient Inperfections: He believe that nelting arises when thermal fluctuations generate transient local loperfections. During melting a cooperative generation of a mode of such imperfections occurs. We wish to generate such fuperfections by electron scattering at temperatures below the melting temperature. Energy loss measurements of the scattered $100 \mathrm{keV}$ electrons would detect generation.

Relationshtp to Other Federally Funded Proyects: We are dolng research in cooperation with Dr. Y. Lwin of Western Illinols University and with Mr. E. Ryan and Dr. J. J. Jackson of the Argonne National Laboratory. Dr. Luin and Mr. E. Ryan are Itradiating pure magnesiun at $3 \mathrm{~K}$. They w111 also study tts annealing using electrical resistance measurements.

Similar research on dilute lead alloys has been completed by the group.

In addition, we are obtaining pure vanadiun and chromium $f$ ron $F$. A. Schmidt of the Ames Laboratory. We plan to make electrical resistance measurementa on these bcc netals.

\section{Publications: (Calendar Year 1975)}

R. Berliner and J, S. Koehler

Temperature Dependence of Transmission Proton Channeling In Ag.

Phys, Rev. B12, 3559-3574 (1975)

J. Koehler

Decrease in the Void Growth Rate by Incerstitial Trapping

Journal of Applted Phys1es $46,2423-2428$ (1975)

R, Berliner and $J$, S. Koehler

The Analysis of Forward Scattering Channeling Data

Radiation Effects (accepted)

R. C. B1rtcher and J. S, Koehler

The Recovery of Lead After Electron Irradiation at $2.5 \mathrm{~K}$

Phys + Rev. (accepted)

Masao Doyana and $J$. S. Koehler

The Relation Between the Fornstion Energy of a Vacancy and the Nearest Nelghbor Interactions 1n Pure Metals and Liquid Metals

Acta Metallurgica (accepted) 
J. S. Koehler

Interstitlals in Metals

Proceedings Conference on Radiation Danage 1n Metals, Gatlinburg, 1975

(to be published)

M.S. Theseg: (Calendar Year 1975)

None

Ph.D. Theses: (Calendar Year 1975)

Robert Charles B1rther (J, S, Koehler, Adviger)

The Recovery of Lead After Electron Irradiation at $1.5 \mathrm{~K}$

May 1975 


\section{GRDA PERSONNEL}

\section{Senior Staff}

Altstetter, Carl J., Professor, Department of Metallurgy and Mining Engineering Amano, Muneyukf, Visfting Research Assoctate Professor, Department of Metallurgy and Mining Engineering

Baer, Donald R., Research Associate, Department of Physics

Beck, Paul A., Professor, Department of Metallurgy and Mining Engineering

Bense1, John P., Research Associate, Department of Physics (Term 12/31/76)

Birnbaum, Howard K., Professor, Department of Ketallurgy and Mining Engineer1ng

Chen, Chee Gregory, Research Associate, Department of Metallurgy and Mining Engineering

Drickamer, Harry G., Professor, Department of Chemical Engineering and Physical Cheristry

Fraser, Hanish L., Assistant Professor, Department of Metallurgy and Mining Englneering

Fritsch, Gerhard H. H, , Research Associate, Department of Physics

Granato, Andrew V., Professor, Department of Physics

Hara, Kinthiko, Research Assoctate, Departwent of Chemistry

Jennison, Dwight, Research Assoclate, Department of Physics

Jonas, Jiri, Professor, Department of Chemlitry

Koehler, Janes S., Professor, Department of Physice

Lezazus, David, Professor, Department of Physics

Linowski, John W., Research Associate, Department of Chenistry (Term 1/31/76)

Hetzger, Marvin, Professor, Department of Metallurgy and Mining Engineering

Meyar, Stephen F., Research Associate, Department of Physics

Otsuka, Kazuh1ro, Visiting Research Associate, Department of Metallurgy and Mining Engineering (Term 3/4/76)

Payne, David, Assistant Professor, Department of Ceramic Englneering

Pugh, E. Neville, Professor, Department of Metallurgy and Mining Englneering

Rowland, Theodore J., Professor, Department of Metalkurgy and Mining Engineering

Seteer, George G., Research Assistant Professor, Department of Physics

Simons, Ralph 0., Professor, Department of Physics; Head of Department

Slichter, Charles P., Professor, Department of Physics

Wayman, C. Marvin, Professor, Department of Metallurgy and Mining Engineering

Wert, Charles A., Professor, Department of Metallurgy and Mining Engineering, Head of Department

Williams, Wendell S., Professor, Department of Physics and of Ceramic Engineering 


\section{Junior Staf $f$}

Abbas, Danlel, Hesearch Ass1stant, Departgent of Phyglcs

Allen, Paul C., Research Assistant, Department of Physics

Aton, Thomas J., Research Assistant, Departnent of Physics

Au, Joseph J., Research Assistant, Departwent of Metallurgy and Mining Engineering

Beggs, Dennis, Reseacch Assistant, Department of Metallurgy and Mining Engineering

Berker, Terre11 D., Research Assistant, Department of Physics

Bethin, James R., Research Assistant, Department of Ceramic Englneering

Bhowal, Prabir R., Research Asgfatant, Department of Metallurgy and Mining

Engineering

Bieg, Kevin W., Research Assistant and GE Fellow, Department of Chemistry

Browning, Barbara, HIH Fellow, Departnent of Physics

Brueminer, Stephen H., Research Assistant, Departuent of Mecallurgy and Hining Englneering

Cassidy, Michael Pt, Research Assistant, Department of Metallurgy and Mining Engineering

Coutur1e, Stephen H., Research Assistant, Department of Physics

Drotn1ng, William D., Research Assistant, Department of Physics (Term $10 / 15 / 75$ )

Eltoukhy, Atef H., Research Assistant, Departaent of Metallurgy and Mining Engineering

Eng, Genghwun, Research Assistant, Depaxtment of Physics

Fay, Roberta M. , Research Assistant, Department of Ceramic Engineering

F1nston, Martin I, , Research Assistant, Departonent of Physics

Fraass, Benedick A., Research Assistant, Department of Physics

Fujita, Jur Ichi, Research Assigtant, Department of Metallurgy and Minting Engtneering

Fury, Michael A., Research Assistant, Department of Chenistry

Heald, Steve H., Research Assistant, Department of Physics

Hockert, Er1c H., Research Assistant and WOCO Fellow, Department of Chemistry

Hook, John W. III, Research Assistant, Department of Chemistry

House, Gary L., Research Assistant and Union Carbide Fellow, Department of Chemistry

Hughes, Scott E., Regearch Assistant, Department of

(Term 9/20/75)

Huson, Thomas E., Research Assistant, Department of Hetallurgy and

Mining Engineering

Isaac, Randall D., Research Assistant and Fellow, Department of Physics

Jackson, Kark S., Research Assistant, Department of Physics

Johnson, David L., Research Assistant, Department of Physics

Johnson, Roger, NIH Fellow, Departwent of Ceranic Engineering

Johnson, Marvin $W_{.}$, Research Assistant, Department of Physice

$\mathrm{Kim}$, Myung-Hwan, Research Assistant, Department of Metallurgy and Mining

Engineer 1ng (Term 9/5/75)

Kiein, David L., Research Assistant, Department of Physics

Klick, David I., Research Assiatant, Department of Physics 
Knodle, Walter S., Research Assistant, Department of Physics (Term $3 / 11 / 76$ )

Ko, Byung, Research Assistant, Department of Ceramic Engineering

Koch, Gerhardus H., Research Assistant, Department of Metallurgy and Mining Eng1neering (Tern 2/27/76)

Kozlowskf, Robert, Research Assistant, Departnent of Physics

Labun, Lance C., Research Assistant, Departaent of Metallurgy and Mining Engineering

Lenahan, Patrick, Research Asalstant, Department of Metallurgy and Mining Engineering

Long, James P., Research Assistant, Department of Physfes

Macrander, Albert T., Research Assistant, Department of Physicg

Matusiewicz, Gerald R., Research Assistant, Department of Metallurgy and Mining Engineering

Menendez, Maria A., Research Assistant, Department of Physics

Mitchell, Dean J., Research Assistant, Departaent of Chemistry

Nelson, Joseph L., Research Assistant, Departient of Metallurgy and Mining Engineering

Park, Sang, Graduate Student, Department of Ceramic Engineering

Poker, David B., Research Assistant and Fellow, Department of Physics

Pontau, Arthur E., Research Assistant, Department of Physics

Rhodes, Howard E., Research Assistant, Department of Physics

Shalvoy, Robert S., Research Assistant, Departont of Metallurgy and Mining Engtineering

Sherman, Robert, Graduate Student, Department of Metallurgy and . Mining Engineering

Shull, Robert D., Research Assistant, Department of Metallurgy and Mining Engineering

Stecke1, Gary L, Research Asststant, Department of Metallurgy and Mining Engineer1ng

Tortorelli, Peter F., Research Assistant, Department of Metallurgy and Mining Engineering

Tust1son, Randal W., Research Assistant, Departaent of Metallurgy and Mining Engineering

Tyner, Craig E., NSF Fellow, Department of Chemietry

Watson, James, Research Assistant, Departnent of Physics

Wilken, Theodore R., Research Assistant, Department of Metallurgy and Mining Engineering (Term 1/22/76)

Yost, Gerald H,, Research Assistant, Departnent of Ceramic Engineering

Zaluzec, Nestor J., Research Assistant, Department of Metallurgy and Mining Engineering

Zapp, Philip E., Research Assistant, Departnent of Metallurgy and Mining Engineering 


\section{Profegsional Staff}

\section{Materials Research Laboratory}

Baker, Judith A., B.A., Research Chemist

Blattner, Richard J., M.S., Research Chemiat

Evars, Charles A. Jr., Ph.D., Senior Research Chemist Hetze, Virginia C., Research Computer Programer

Ward, Ian D., Research Petallurgist

Willians, Peter; Ph.D., Re6earch Chenist

Woodhouse, Jahn B. B.A., Research Microprobe Analyst 


\section{PUBLICATIONS}

(Calendar Year 1975)

There were 40 ERDA-supported publications for the Calendar Year 1975. In addition, there were 30 papers in process of publication.

ED-02-01-01-0 structure of Materials

Paul A. Beck and C. P. Flynn, "Ioterpretation of the Susceptib111ty of Paramsgnetic N1cke1," Solid State Commun. 18, 127-130 (1975).

T. P. Darby and C. M. Waynan, "Growth of Gold Thin Film Dendriteis on Graphite Substretes," J, Cryst, Growth 29, 98-108 (1975).

T. P. Darby and C. M. Wayman, "Nucleatlon and Growth of Gold Films on Graphite I: Effects of Substrate Condition and Evaporation Rate," J. Cryst. Growth 28, 41-52 (1975).

A. Mukhopadhyay, R. D. ShuIl, and Faul A. Beck, "Relaxation and Magnetic Clusters in Mictoogagnetic Cu-Hn Alloys," J. Less Conmon Metals 43, 69-82 (1975).

K. Otsuka and C. M. Wayman, "On the Shape Menory Effect In Internally Faulted Martensites," Scripta Ket. 9, 1017-1022 (1975).

R. D. Shull and Paul A. Beck, "Mlctomagnetlc to Ferrowagnetic Transition in Cr-Fe Alloys," AIP Conf. Proc. 24, 95-96 (1975).

H. C. Tong and C. M. Waynan, "Thermodynanis Considerations of "Solfd State Engines' Based on Thernoelastic Maxtens1t1c Transformations and the Shape Memory Bffect," Met. Trans, 6A, 29-32 (1975).

H. C. Tong and C. M. Waymsn, "Thermodynanics of Thermoelastic Martensitic Transformations," Acta Meta11. 23, 209-215 (1975).

C. M. Wayman, "Defornation, Mechanisns and 0ther Characteristics of Shape Memory Alloys," Shspe Memory Effects in Alloys, edited by J. Perk1ns (Plenum Pub. Co., New York, 1975), Pp. 1-28.

C. M. Wayman, "Shear Transformations and Microstructure," Meta1lography g, $105-130$ (19)5).

C. M. Wayman and T. P. Darby, "kucleation and Growth of Gold Films on Graphite II: The Effect of Substrate Temperature," J. Cryat. Growth 28, 53-67 (1975).

Lance Breger, Marvin Johnson, and Wendell W11l1ams "Plezoelectric Response of Inorganic and Biological Materials Subjected to Inhomogeneous Stress," J. Appl. Phys. (subnitced to). 
Dwight R. Jennison and A. Barry Kunz, "Degree of Ionicity in Crystalline $\mathrm{KaF}, \mathrm{HaCl}, \mathrm{SrF}_{2}$ and $\mathrm{SrCl}_{2}$ and Found by Local Orbitals Hartree-Fock," Phys. Rev. (submttted to).

J. Jonas, T. DeFries, and D. J. Hilbur, "Kolecular Motlone in Conpressed Liquid Hater," J. Chem, Phys. (In press).

S. B. Kulkarni and W. S. Williams, "Dislocation Velocities and Electronic Doping in Sillcon," J. Appl. Phys. (subritted to).

J. W. Linowski, Nan-I Llu and J. Jonas, "The Effect of Density and Temperature on the Hydroxyl Proton Chemical Shift In Liquid Ethanol," J. Magnetic Resonance (in press).

R. Otauka and G. H. Wayman, "Pseudoelasticity and Streas-Induced Hartensitic Transfortations," Reviews on the Deformation Behavior of Materials (accepted).

\section{ED-02-01-02-0 Mechanical Properties}

H. R. Btrnbaum and H. Wadley, "Hydrogen Enbritclenent of Molybdenum," Seripta Met. 9, 1113-1116 (1975).

D. G. Chakrapani and E. N. Pugh, "The Transgranular SCC of a 24 -Al Alloy: Crystallographic, Fractographic and Acoustic-Rnsission Studies," Metall. Transactions 6A, 1155-1163 (1975).

D. G. Chakrapant and E. N. Pugh, "On the Practography of Transgranular Stress-Gorrosion Failutes in a Mg-Al Alloy," Corrosion 31, 247-252 (1975).

Hamish L. Fraser and Ian P. Jones, "A Note on the Increase In Usable Foil Thickness in Scannins Transmission Electron Hicroscopy," Phil Hag. 31, 225-228 (1975).

H. L. Fraser, N. J. Zaluzec, J. B. Woodhouse, and L. B. Sis, "On the Feasibility of Quantitative Microchenical Analysis of Thin Metal Foils," 33rd Anntual Proceedings Electron Hicroscopy Soclety, G. W. Bailey, ed. (Las Vegas, Nevada 1975) pp. 106-107.

Philippe Lecocq and Charlea Wert, "Equillbrium In Hydride Formation In Tantaltin," Thin Solld P11ms 25, 77-84 (1975).

R. E. Mattas and H. K. BIrnbaum,"Isotope Effects on the Motion of $0-H$ Clusters in $\mathrm{kb}, "$ Acta Metall. 23, 973-977 (1975).

M. Hetzger, "Intergranular Corrosion of single Phase Aluminum as Pitt1ng Phenomenon," Journal de Physique 10, C4-387-393 (1975).

J. L. Nelson and E. N. Pugh, "The Occurrence of Transgranular CleavageLike Fracture in an Al-2n-Mg Alloy During Tensile," Hetall. Trans. 6A. 14\$9-1460 (1975). 
M. F. Bluem and H. K. Birnbaum, "Determination of the Thermally Activated Deformation Parameters in $\mathrm{Nb}$ and Nb-N Alloys," Proceeding Int "1. Conf. on the Strength of Hetals, France, 1976 (to be published).

D. G. Chakrapani, G. H. Koch, and E. N. Pugh, "On the Mechanisn of SCC in a Mg-Al Alloy," Proceed1ngs Sixth International congress on Metallic Corrosion, Australia, 1975 (to be published).

D. G. Chakrapani and E. H. Pugh, "Hydrogen Enbritclement in a Ma-Al Alloy," Metall. Trans. (accepted).

H. Gabel, J. A. Beavers, J. B. Woodhouse, and E. N. Pugh, "The Structure and Composition of Thick Tarnish Filns on Alpha-Phase Copper Alloys," Corrosion (accepted).

M. L. Grossbeck, Peter Williams, Charles A. Evans, Jr, , and H. K. Birnbasn. "Application of Ion Probe Analysis to Studiea of hydrogen Behavior in Solids," Phys. Status Solldil A (in preas).

Peter Williams, Charles A. Evans, Jr., Martin L. Grossbeck, and Howard K. Birnbaum, "Ion Microprobe Analysis for Niobium Hydride in Hydrogen-Embrittled Nioblum," Anal. Chen, (1n press).

ED-02-01-03-0 Physical Properties

T. J. Rowland, "A $14 \mathrm{~N}$ Nuclear Relaxation Study of Hydrogen Bonding in Diethylanine-Alcohol Solutions," J. Chen. Phys. 63, 608-612 (1975).

T. J. Rowland and A. C. Yen, "A Study of Precipitation Using Nuclear Magnet1c Resonance: Cu-2 wt.Z Be," Acta letall. (in press).

\section{ED-02-02-02-0 Experimenta1 Research}

V. M. Cheng, P. C. AIIen, and D. Lazarus, "Pressure Coefficient of Thermoelectric Power of Platinum/Platinum-10\% Rhodium and Chromel/ Alumel Themocouples," Appl. Phys, Lett. 26, 6-7 (1975).

V. M. Cheng, W. B. Daniels, and R. K. Crawford, "Melting Parameters of Methane and Nitrogen from 0-10 K1lobers," Phys. Rev. B11, 39723975 (1975).

R. K. Crawford, W. B. Daniels, and V. M. Cheng, "Melting and Its Relation to Molecular Orientations in the Flutd and Solid Phases of $\mathrm{N}_{2}$ and $\mathrm{CH}_{4}, "$ Phys. Rev. A12, 1690-1696 (1975).

H. G. Drickaner, "Exploratory Research at High Pressure," Matertals Jnder Pressure, editad by T. Hirone (taruzen Press Co., Tokyo, 1975), PP. 1-35.

H. 6. Dxickamer, "H1gh Pressure Studies of Electronic Structure in Solids," International Review of Science - Inorganic Chenistry, Vol. 10, solid state chetistry, edited by L. E. J. Roberts (Butterworths, London, 1975), pp. 1-33. 
H. G. Drickamer, "The Effect of Pressure on the Electronic States of Organic Sollds," Proceedinge of Interabtional Conference on Organic Synethesis, Belg1um, 1974. Pure and Applied Chem. 43, 379-399 (1975).

J. A. Garber and A. V. Granato, "Pourth-0rder Elastle Constants and the Temperature Dependence of Second-Order EJastic Constants in Cubic Materials," Phys. Rev, BLl, 3998-4007 (1975)

J. A. Garber and A. V. Granato, "Theory of the Temperature Dependence of Second-Order Elastic Constants in Cublc Materials," Phys. Rev. B11, 3990-3997 (1975).

H. M. Gilder and D. Lazarus, "Role of Vancancy Anharmonictity on NonArrhenlus Diffusional Bekavior," Phys. Rev. B11, 4916-4926 (1975).

A. V. Granato, "Ultraoonlc \$tudies of Mechantcal Strength," Ultrasonics Sympos1um Procepd1ngs IEEE Cat. \$75 CHO 994-4SU (1975).

R. D. Isaac and R. B. Schwartz, "A Simple Persistent Switch for Superconducting Solenoids," Rev. Scl. Instrun. 46, 638 (1975).

Joan L. Mitchell and David Lazarus, "Effect of Heterovalent Impuritieg Codiffusing with Monovalent Tracers in Ionte Crystals," Phys. Rev. B12, 734-752 (1975).

R. B. Schwartz and A. V. Granato, "Measurenent of the Force-Diatance Profile for the Interaction Between a Dislocation and a Point Defect," Phys. Rev, Let. $\underline{34}, 1174-1177$ (1975).

Charles P. S11chter, "Some Scientific Contribution of Herbert S. Gutowsky," J. Magnetic Resonance 17, 274-280 (1975).

K. D. Swartz, W. Bensch, and A. V. Granato, "The Seçond-, Th1rd-, and Fourth-Order Elastic Constants of Beta Brass," Phys. Rev. B12, 2125-2131. (1975).

W. F. Weaton and A. V. Granato, "Cubic and Hexagonal Single-Crystal Elastic Constants of a Cobalt-N1ckel Alloy," Phys. Rev. B12, 5355-5362 (1975).

D. G. Wilson and H. G. Dirickamer, "High Pressure Studies on Spiropyrans," J. Chem. Phys. 63, 3649-3655 (1975).

Janes B. Boyce and Charles P. Slichter, "Conduction-Electron Spin Density Around $\mathrm{Fe}$ Inpurities in $\mathrm{Cu}$ Above and Below the Kondo Femperatures," Phys. Rev. (subnitted to).

J. B. Boyce and C. P. Slichter, "Deteralnation of the Energy Level Parameters and Crystal Field splitcing for Fe In Cu," Proceedings Conference on Magnetism and Magnetic Materials, Philadelphia, Pa., 1975 (ta be published).

R. K. Crawford, W. F. Lewis, and W. B. Daniels, "Thernodynanics of Solld Argon at High Temperatures," Solid State Phys. C (to be published). 
W. D. Drotning and H. G. Drickamer, "High Pressure Optical Studies of . Doped Alkali Halides. I. Peak Shifte and Peak Shape Changes,"

Phys. Rev. (in press).

W. D. Drotning and H. G. Drickamer, "High Pressure Optical Studfes of Doped Alkali Halides. II. Jahn Teller Bffects," Phys. Rev, (In press).

W. D. Drotning and H. G. Drtcikamer, "H1gh Pressure Optical Studies of Doped Alkall Halides. III. Rates of Electron TransFer Processes," Phys, Ret, (in press).

W. D. Drotning and H. G. Drfckamer, "High Preasure Optical Studies of Doped Alkali halides. IV. Mixed Crystals," Fhys. Rev. (In press).

D. Follstaedt and C. P. Sllchter, "An MMR Search for Charge Denelty Waves," Phys. Rev. (submitted to).

A. V. Granato, "Dislocation-Defect Interactions and Hechantcal Properties of Crystals," proceedings of International Conference on Radiacton Damage in Solids, Gaclinburg, 1975 (to be published).

R. J. Helson, N. Holonyak, Jr., W. R. H1tchens, D. Lazarus, and A. Altare111, "Presaure Experinent Determination of the DirectIndirect Transition in the Quaternary $\operatorname{In}_{1-x} \mathrm{Ga}_{\mathrm{A}} \mathrm{P}_{1-z^{\mathrm{As}}}$," Solid State Commun. (subsitted to).

L. A. Schwalbe, "Rquilibrium Vacancy Concentration Measurements in . Solld Argon," Phys. Rev. B (to be published).

C. P. S1ichter, "KMR Studies of the Kondo Effect Revisited," Proceedings Conference on Magnet ism and Magnet 1c Materials, Phtladelphfa, Pa., 1975 (to be published).

C. E. Tyner, W. D. Drotaing, and H. G. Drlckamer, "Asymetric Line Shapes of Localized Dptical Excltationg tn Condened Systens,"

J. App1. Phys. (accepted).

ED-02-02-04-0 Particle-5ol1d Interactions

R. Berliner and J. S. Koehler, "Tenperature Dependence of Transalssion Proton Channeling in Ag," Phys. Rev. B12, 3559-3574 (1975).

J. Koehler, "Decrease in the Vold Growth Rate by Interstitial Trapping,"

J. App2. Phys. 46, 2423-2428 (1975).

R. Berliner and J. A. Koehler, "The Analysis of Forward Scattering Channeling Data," Radiation Effects (accepted).

R. C. Birtcher and J. S. Koehler, "The Recovery of Lead After Electron Irradiation at $1.5 \mathrm{~K}$," Phys. Rev. (accepted). 
Masao Doyama and J. S. Koehler, "The Relation Between the Formation Energy of a Vacancy and the Nearest Netghbor Interactions in Fure Metals and Liquid Metals," Acta Metallurg1a (accepted).

J. S. Koehler, "Interstitials in Metale," Proceedings Conference on Radiation Damage in Metals, Gatilnburg, $19 \overline{75}$ (to be published). 


\title{
Ph.D. DISSERTATIONS
}

(Calendar Year 1975)

\begin{abstract}
Eleven Ph.D. Theses were conpleted and degrees granted with ERDA support for the Calendar Year 1975.

D. R. Aadsen (R, 0, S1mmons, Adviser), "Lattlce Parameter and Thermal
\end{abstract} Expansion in Sol1d Methane," October 1975.

Joseph Gaty Baldoni II (H. S. Wtlliams, Adviser), "High Temperature Defornation Behavior of Cemented Carbide Cutting Tools," January 1975.

Robert Charles Birtcher (J. S. Koehler, Adviser), "The Recovery of Lead After Electron Irradiation at $1.5 \mathrm{~K}$," Hay 1975 .

D. G. Chakrapani (E. N. Pugh, Adv1ser), "Transgranular Stress-Corrosion Cracking of a Magnesiun-Aluninu Alloy," May 1975.

S. Chakravorty (C. M. Wayoan, Adviser), "Crystallography of the Thermoelastic Martensitic Transforation in Ni-Al Alloys," October 2975.

W. D. Drotning (H. G. Drickaner, Adviser), "Luminescence of ImpurityActivated Alkali Halides Under High Pressure," October 1975.

David Martin Follstaedt (C. P. Slichter, Adviser), "A Nuclear Hagnetlc Resonance Study of Dilute Copper-Vanadium Alloys," January 1975.

Subhash B. Kulkarni (W. S. Williams, Adviser), "Velocteles of Screw and 60"-D1slocations in Intrinsic and Extrinstc silicon," October 1975.

David Thomas Read (A. V. Granato, Adviser), "Blas Stress Detection of Dislocation Resonance in Lead," May 1975.

D. Shah (C. J. Altstetter, Adviber), "Deformation of Vanad1um Containing Dispersed $\mathrm{V}_{16} \mathrm{~N}$ Particles," October 1975.

D. G. Wilson (H, G. Drickamer, Adviser), "Photochroule Studies of Spiropyrans," May 1975. 
M.S. DISSERTATIONS

(Calendar Year 1975)

Eight M.S. theses were completed and degrees granted with ERDA support For the Calendar Year 1975.

M. Cassidy (C. M. Waynan, Adviser), "An Electron Microscopy Study of the Substructure of B-Hydride in Vanadium," May 1975.

E. N. Hockert (H. G. Drickamer, Adviser), "The Effect of Pressure on the Electronte Spectra of Sone Sallcylikineantline," May 1975.

G. L. House (H. G. Drickaner, Adviser), "Effects of High Pressure on the Luninescence of Zinc Sulfide Phosphors," May 1975.

Scott E. Hughes (H. L. Fraser, Adviger), "A Preliminary Study of the Morphology of Hydride Precipltation in Tantalus," October 1975.

R. W. Levie (C. A. Wert, Advibar), "The Solubillty of Aydrogen In Vanadian," August 1975 .

James G. Sheltens, (M, Metzger, Adviser), "Scanning Electron Microscope Study of Pitting on Aluminue in Sulfuric Acld Contalning chloride," 1975.

C. E. Tyner (H. G. Drickamer, Adviser), "Effects of Pressure on Oxygen Dominated Phosphors," Hay 1975.

T. Wilken (C. A. Wert, Adviser), "The Horphological Structure Produced During Reduction of Blue Tungsten Oxide to Tungsten Metal," May 1975. 